\title{
Symbiotic adaptation of prokaryotic microorganisms in extreme deep- sea environments
}

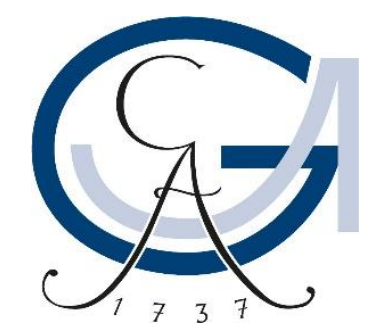

Dissertation

for the award of the degree

"Doctor rerum naturalium" (Dr.rer.nat.) of the Georg-August-Universität Göttingen

within the doctoral program Biology of the Georg-August University School of Science (GAUSS)

submitted by

Blanca Rincón Tomás

from Madrid, Spain

Göttingen, 2018 



\section{Thesis Committee}

PD Dr. Michael Hoppert, Department of General Microbiology, Institute for Microbiology and Genetics, Georg-August-University Göttingen

Prof. Joachim Reitner, Department of Geobiology, Geosciences Centre, Georg-August University Göttingen

\section{Members of the Examination Board}

Reviewer: PD Dr. Michael Hoppert, General Microbiology, Institute for Microbiology and Genetics, Georg-August-University Göttingen

Second Reviewer: Prof. Joachim Reitner, Department of Geobiology, Centre for Geosciences, Georg-August University Göttingen

\section{Further members of the Examination Board}

Prof. Rolf Daniel, Department of Genomic and Applied Microbiology, Institute for Microbiology and Genetics, Georg-August-University Göttingen

Prof. Luis Somoza, Department of Marine Geology, IGME Geological Survey of Spain

Prof. Heike Krebber, Department of Molecular Genetics, Institute for Microbiology and Genetics, Georg-August-University Göttingen

Prof. Volker Thiel, Department of Geobiology, Centre for Geosciences, Georg-August University Göttingen

Date of the oral examination: December $6^{\text {th }}, 2018$ 

"If you really want to study evolution, you've got to go outside sometime, because you'll see symbiosis everywhere"

Lynn Margulis (1938 - 2011) 



\section{Declaration}

I hereby declare that this thesis has been written independently, without use of other sources and aids than those cited.

Blanca Rincón Tomás

Göttingen, November $8^{\text {th }} 2018$ 



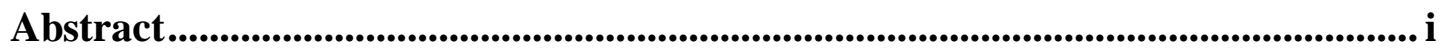

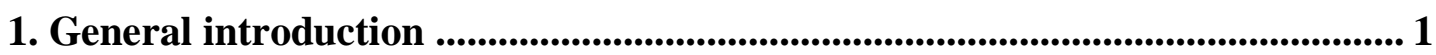

1.1 Symbiosis everywhere

1.2 Hydrothermal vents, cold seeps and other deep-sea reduced environments........................... 3

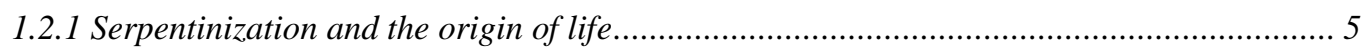

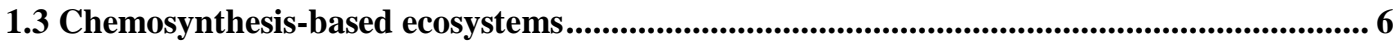

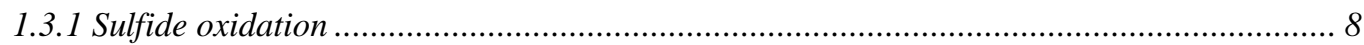

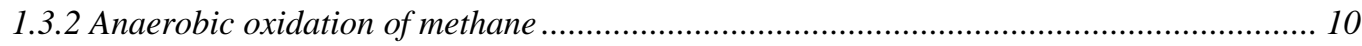

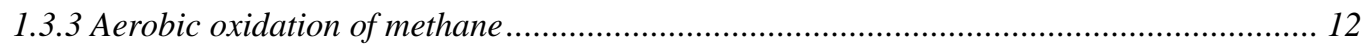

1.3.4 Methane production ……………………………................................................... 14

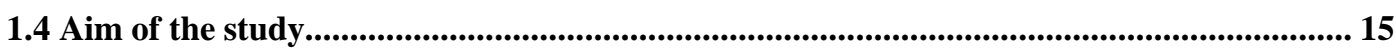

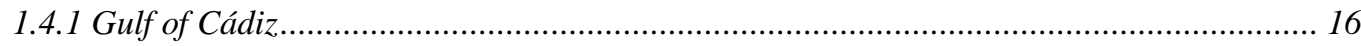

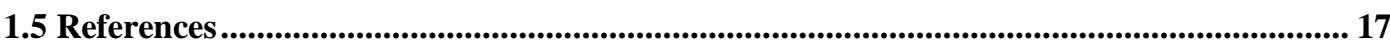

2 Cold-water corals affected by hydrocarbon-rich seepage - living on the edge

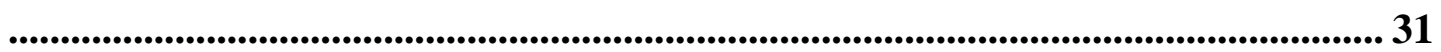

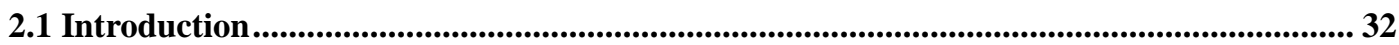

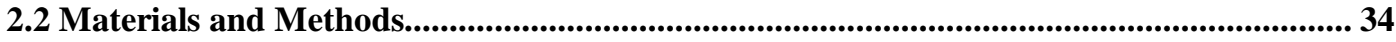

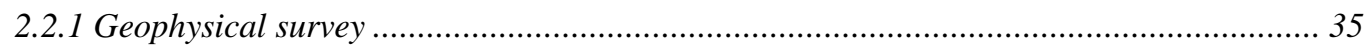

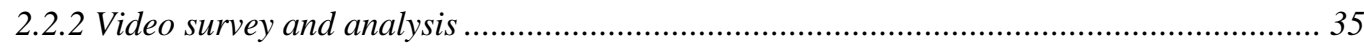

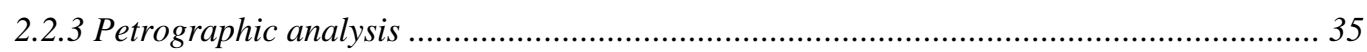

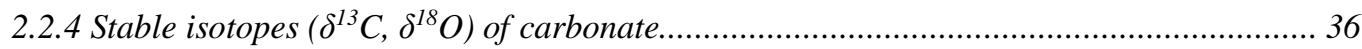

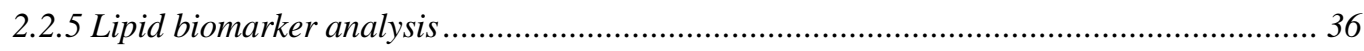

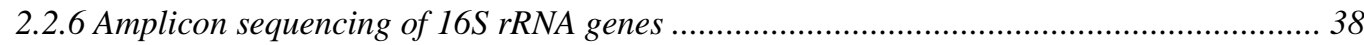

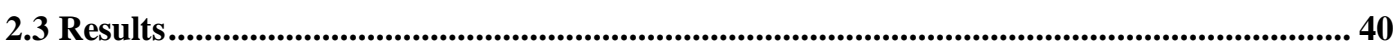

2.3.1 The Pompeia Province — geological settings .............................................................. 40

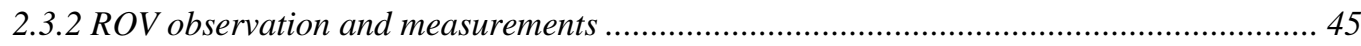


2.3.3 Petrography and stable isotopes signatures of carbonates $\left(\delta^{18} \mathrm{O}, \delta^{13} \mathrm{C}\right)$ 49

2.3.4 Lipid biomarkers and compound specific isotope signatures .................................... 54

2.3.5 DNA inventories (MiSeq Illumina sequences) .......................................................... 56

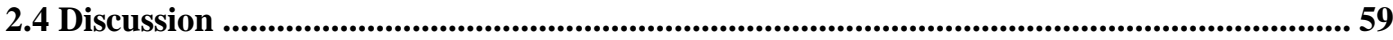

2.4.1 Evidence of hydrocarbon-rich seepage affecting the Pompeia Province ......................... 59

2.4.2 Ecological meaning of hydrocarbon-rich seepage for CWCs................................... 61

2.4.3 Spatio-temporal co-existence of CWCs and chemosynthetic organisms - the buffer effect 62

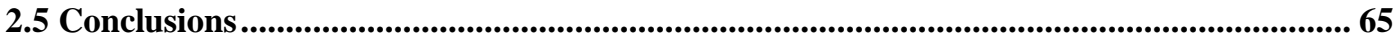

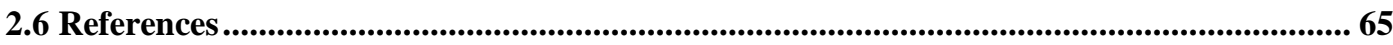

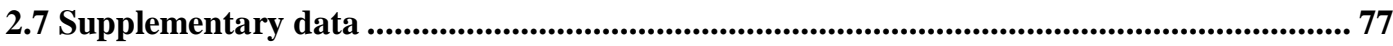

3 Small Siboglinidae worms under scrutiny - including their tube as a part of

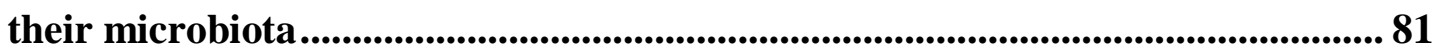

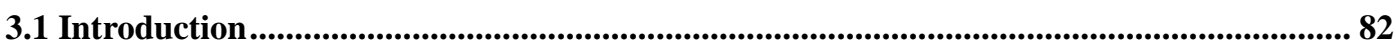

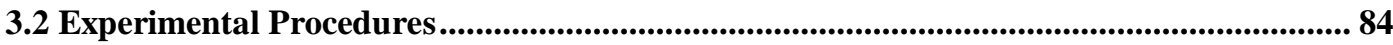

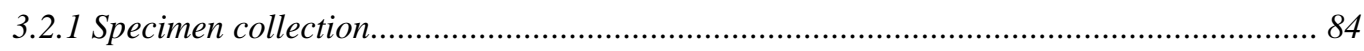

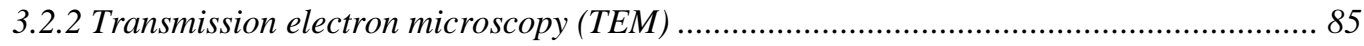

3.2.3 Scanning electron microscopy (SEM) and energy-dispersive X-ray spectroscopy (EDX)

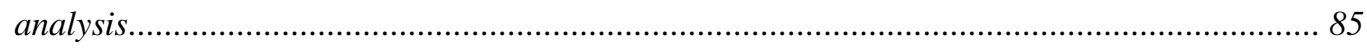

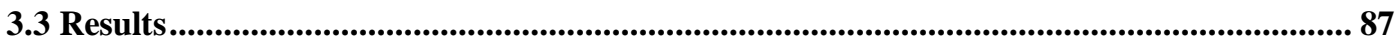

3.3.1 Samples and in situ variables' measurement ............................................................ 87

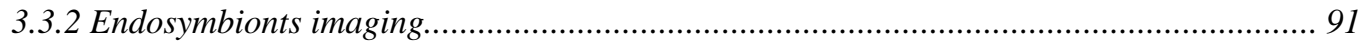

3.3.3 Structure and composition of the tubes .................................................................. 92

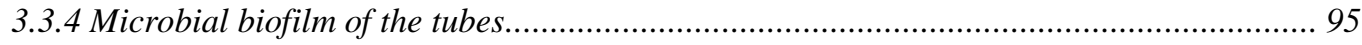

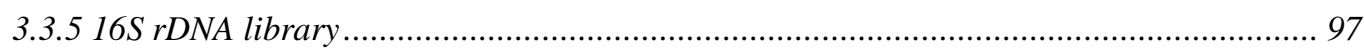

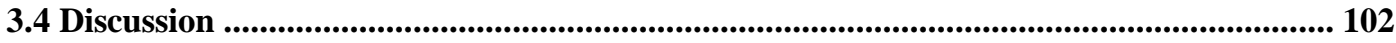

3.4.1 Endosymbionts in Siboglinidae worms ................................................................ 102

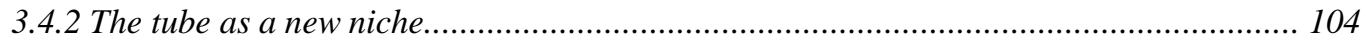


3.4.3 The microbiota of small Siboglinidae worms ......................................................... 106

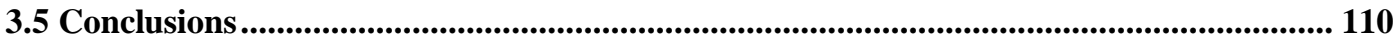

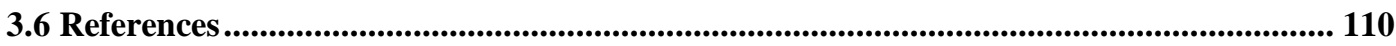

3.6 Supplementary data .......................................................................................................... 117

3.6.1 Worm observed inside its tube in Al Gacel MV sample ............................................. 117

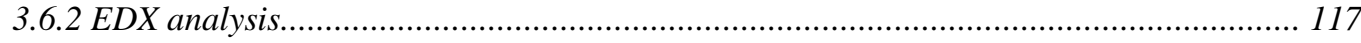

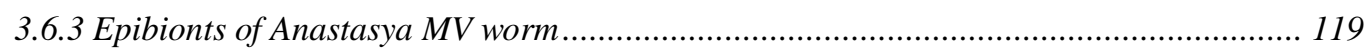

4 General discussion ............................................................................................................ 121

4.1 Symbiosis in the Gulf of Cádiz........................................................................................... 122

4.1.1 Anaerobic oxidation of methane driven in symbiosis .......................................... 123

4.1.2 Characteristic chemosynthetic invertebrates ................................................... 124

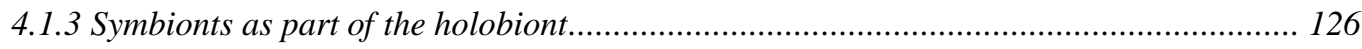

4.2 Adaptation of prokaryotes in extreme deep-sea environments ....................................... 127

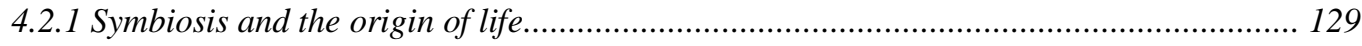

4.3 Reconstructing the tree of life: symbiosis as a successful evolutionary strategy .............. 130

4.3.1 Goodbye neo-Darwinism, welcome horizontal interactions .................................. 131

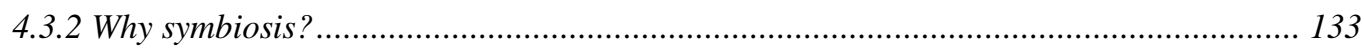

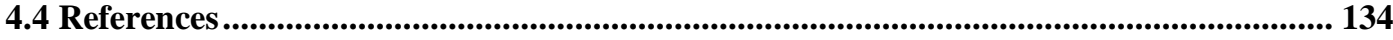

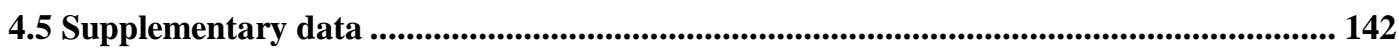

4.5.1 Environmetal 16S rDNA library of Beggiatoa-like biofilms (Anastasya MV) ............... 142

4.5.2 Small AOM-carbonate clasts in El Cid MV........................................................ 145

5 Conclusions ......................................................................................................................... 146

Acknowlegdements .................................................................................................................. 148 



\section{Abstract}

Extreme deep-sea environments are widespread and intensively studied in the last decades. They are of special interest since living organisms in those habitats happen to live at the expenses of the fluids emitted from the subseafloor via chemosynthesis. Unlike most common ecosystems, which rely on photosynthesis, primary producers obtain their carbon and energy sources through chemical reactions, i. e. sulfide oxidation, sulfate reduction, methane oxidation. Furthermore, the conditions given in hydrothermal vents are similar to those given in primitive Earth and metabolisms found in these ecosystems may provide information about the first metabolisms on Earth (origin of life is estimated to have occurred ca. 3.6 - 4 Ga years ago). For instance, methanogenesis (abundant in hydrothermal vents and also present in cold seeps) is considered a good candidate for being the metabolism driven by the last unique common ancestor (LUCA), since the process of serpentinization observed in alkaline hydrothermal fields is capable of producing hydrogen $\left(\mathrm{H}_{2}\right)$ abiotically. Furthermore, anaerobic oxidation of methane (AOM) may have also appeared in the early Archaean, although earliest evidences date from $2.7 \mathrm{Ga}$ years ago and it seems this metabolism was not stable until shortly before the Great Oxidation Event (ca. 2.4 Ga ago). Nowadays, AOM is the major sink of methane in deep-sea oceans, driven by a symbiotic relationship between ANME archaea and SRB bacteria.

Extreme deep-sea environments are also characterized by the common presence of certain clades of marine invertebrates (mostly tubeworms and bivalves). DNA analysis performed on organisms living in modern hydrothermal vents and cold seeps point out that their ancestors belong to shallower waters, indicating they have colonized the deep-sea more recently. Therefore, for these organisms to live in these reduced environments is harsh and they have adapted to low oxygen, high pressure and extreme temperatures. Interestingly, intensive studies performed on these animals have revealed they harbor in their organs chemosynthetic endosymbionts. These prokaryotes provide with organics the invertebrates, while they enjoy the easy access to the metabolites needed for chemosynthesis. 
In this study, we analyze the symbiotic adaptation of prokaryotes in extreme deep-sea environments. To do so, we have sampled mud volcanoes in the Gulf of Cádiz for further understanding of this relationship between organisms. In the first chapter, we have focused on the existing relationship between cold-water corals and seepage of fluids in the Pompeia Province, since they are found related to active seepage and there is no evidence of a chemosynthetic life-style of the corals. Results indicate that the corals use AOM-derived carbonates as the hard substrata they need to settle and flourish. Furthermore, they are capable of living upon seeping fluids by means of chemosynthetic microorganisms, i. e. AOM-related microorganisms, siboglinids, and sulfide-oxidizing bacterial mats, which feed on the emitted fluids and protect the corals — the so-called the buffer effect.

The second chapter is focused on the finding of small Siboglinidae worms in four different mud volcanoes in the Gulf of Cádiz (El Cid MV, Bonjardim MV, Al Gacel MV and Anastasya MV). Although not all of them were alive, tubes recovered from those volcanoes currently active (Al Gacel MV and Anastasya MV) harbored a microbial biofilm related to them. This finding suggests that the worms' microbiota is more extended as previously thought. Furthermore, DNA analyses revealed changes in the worms' microbiota depending on the mud volcano, i. e. depending on the seepage activity.

Due to the common observations of symbiosis in the Gulf of Cádiz and other extreme deep-sea environments, we aim to elucidate the importance of symbiosis not only in these ecosystems but in the history of evolution. To do so we have collected data from our study and other reported studies to have a better and global understanding of the role of symbiosis in evolution. We have concluded that symbiosis is indeed a major motor in evolution and therefore evolutionary and theoretical biology needs to re-think the basis of the actual theory of evolution. 


\section{General introduction}

The term symbiosis was used for the first time in a biological context in 1879 by Anton de Bary as "Erscheinungen des Zusammenlebens ungleichnamiger Organismen, der Symbiose, wie man kurz und allgemein sagen kann" (De Bary, 1879), which translated into English means "symbioses, namely, the living together of differently named organisms" (Oulhen et al., 2016). More than 100 years after, the definition of symbiosis is controversial and can be differently defined depending on the author (Martin \& Schwab, 2012). I would like to define symbiosis as the long-term relationship between different organisms, which could ultimately end in the creation of a new, evolved organism (see Kiers \& West, 2015). Therefore, symbiotic interactions should not only confer a beneficial situation in at least one of the involved ones, but the resulting mechanism of adaptation should imply an evolutionary advantage for all of them.

Studying the symbiotic adaptation of microorganisms in extreme deep-sea environments requires a previous knowledge of the habitat and the organisms therein. Likewise, similar studies in other environments may provide useful information about what can we expect from our study. Therefore, I first introduce a summary of the most relevant information related to the aim of this study, followed by the analyses performed during this study and an ultimate discussion about the role of symbiosis in extreme deep-sea environments and its impact on evolution.

\subsection{Symbiosis everywhere}

It is impossible for any species to survive alone. We need other organisms as nutriotional source (except primary producers), but also to be able to adapt to certain environmental conditions. In addition to extreme deep-sea environments — introduced in the next sections —, symbiotic adaptions are observed worldwide. Numerous examples of symbiosis are well known in different ecosystems. For instance, lichens, consider individual organisms themselves, are the result of a permanent symbiosis 
between a photosynthetic organism (cyanobacteria or alga) and a fungus (De Bary, 1879). The alga provides nutrients to the host, while the fungus protects the alga from drying out and allows it to colonize niches outside the water. Mycorrhiza and rhizobia are another predominant type of symbiosis. Heterotrophic fungi and nitrogen-fixing bacteria are attached to the roots of the plants, allowing them to colonize soils which lack of nutrients or, concretely in the case of rhizobia, of nitrogen compounds. As a reward, the fungi and the bacteria are constantly supply with food (Denison \& Kiers, 2011). Likewise, some invertebrates such as giant clams, green hydra, sponges and corals in shallow waters have even deleted one trophic level by living in symbiosis with photosynthetic organisms (Muscatine \& Lenhoff, 1963; Venn et al., 2008).

The so-called normal flora of an organism, i. e. intestinal flora, skin flora, oral flora, urogenital flora, describes all the microorganisms related to an individual multicellular organism, and many of them live in symbiosis. For instance, the intestinal microbes in mammals allow them to assimilate some nutrients than otherwise the animal would not be able to assimilate. Bacteroidetes bacteria have been found to break down xyloglucans, which are found in vegetables and fruits (Larsbrink et al., 2014). The bacteria provide usable nutrients to humans, while they get access to food and stay in a welfare niche. Interestingly, the same way Riftia pachyptila is considered a chemosynthetic organism since the symbionts and the worm are contemplated as a one, an individual human should be considered as the multicellular organism plus their flora. In 1991, Margulis and Fester introduced for the first time the term holobiont, as the assemblage of different organisms that form an ecological unit which has been originated via symbiosis. However, this concept is still under discussion and nowadays the holobiont encompasses a host plus its microbiome, including symbiosis, commensalism and even parasitism (Douglas \& Werren, 2016).

Furthermore, the origin of eukaryotic cells (1.5 - 2 Ga ago; Hallmann, 2014; LópezGarcía \& Moreira, 2015) - is the perfect example of the power of symbiosis in evolution. What a first seemed to be an archaeon feeding on an aerobic bacterium, it ended up in a permanent symbiosis which ultimately created a new type of organism. The aerobic bacterium was living in the food-rich environment of the archeon's body, 
while the archaeon gained the capability of living in a world rich in oxygen, turning it into chemical energy to ultimately turn it into food. The two microorganisms merged into a single, larger eukaryotic cell (Sagan, 1967; Koonin, 2015). This symbiosis is the ancestor of all multicellular life. Thus, symbiosis is not only highly present in modern ecosystems, but in the history of life.

\subsection{Hydrothermal vents, cold seeps and other deep-sea reduced environments}

In 1977, scientists onboard the R/V Knorr and R/V Lulu during the Galápagos Hydrothermal Expedition discovered for the first time the existence of hydrothermal vents with the famous Deep Submergence Research Vehicle Alvin (Ballard, 1977; Lonsdale, 1977). They had previous suspicions on the existence of these vents, but what they did not expect was to find large communities of living organisms related to them (Ballard, 1977). Since then, the common resemblance between the deep-sea floor and a desert changed. Instead, it seemed to be a desert with living oases. The famous Riftia pachyptila giant tubeworms (Jones, 1981), giant clams, mussels, crabs and many other fauna well known nowadays were first observed in this expedition (Ballard, 1977). Scientists realized that photosynthesis could not be the metabolism sustaining this major ecosystem, since no light reaches these sites. In fact, they discovered that chemolithoautotrophic microorganisms were the base of the food chain in these ecosystems, via chemosynthesis (Jannasch, 1984; Jannasch \& Mottl, 1985). They use some of the emitted compounds (e. g. methane, carbon dioxide, hydrogen and sulfide) to produce energy and organic molecules needed to sustain themselves and the rest of organisms.

Currently, many other vent sites and other living oases have been discovered around the world (e. g. Van Dover, 2000). Cold seeps, whale falls and even wood falls are also found in the deep-sea floor and are widely distributed. They have in common the abundance of reduced chemical compounds (e. g. sulfur, carbon dioxide, methane) due to the emission of under seafloor fluids (hydrothermal vents, cold seeps) or to the decay and decomposition of organic material that sinks into the bottom of the ocean 
and leads to a micro-environment itself (whale falls, wood falls). Although they differ in their origin and geological characteristics, these reduced environments harbor astonishing living communities that rely on chemosynthesis (see section 1.2. for more details).

Hydrothermal vents and cold seeps are geological features formed due to tectonic activity. Hydrothermal vents are normally related to volcanic areas with separation or subduction of tectonic plates, where the cold seawater $\left(\right.$ ca. $\left.2{ }^{\circ} \mathrm{C}\right)$ percolates down the ocean's crust through fissures and faults, and mixes with the hot hydrothermal fluids and mantel magma (ca. $400{ }^{\circ} \mathrm{C}$ ) under the seabed. The water is then heated and expulsed into the water column rich in reduced metals ions, carbon dioxide and monooxide, hydrogen, sulfide and variable amounts of methane, all resulting in a low pH (2 - 3) (e.g. Von Damm, 1995; Martin et al., 2008). Consequently, hydrothermal vents are characterized by chimneys or "smokers" formed by the rapid precipitation of high temperature hydrothermal fluids, locally affected by hypoxia or even anoxia, and a decreasing gradient of the water temperature as the distance increases from the emission spots. Chemosynthetic fauna is normally found related to the chimneys and covering the surface. Hydrothermal vents are distributed along the margin of the tectonic plates, such as the Galápagos Rift (Ballard, 1977), the Mid-Atlantic Ridge (Rona et al., 1986) and the East Pacific Rise (Haymon et al., 1991).

Likewise, cold seeps also filtrate subseafloor fluids into the water column, but at the same temperature as the seawater $\left(2-10{ }^{\circ} \mathrm{C}\right.$ but can reach up to $\left.27{ }^{\circ} \mathrm{C}\right)$. They are normally related to hydrocarbon-rich reservoirs (e. g. Levin, 2005). Compressional forces on these pools, as a result of tectonic activity, derive to the upwards migration of these fluids and seepage onto the seafloor. Cold seeps are normally found forming pockmarks (pool-like depressions) with related authigenic carbonates and chemosynthetic fauna. Bubbling from gas hydrates occurs when the site is active. Sometimes, seepage in cold seeps can be explosive, expelling reduced muddy sediments with different rock-fragments from lower stratigraphic layers (known as mud breccia) and leading to the formation of mud volcanoes (e. g. León et al., 2012). Cold seeps are normally related to passive margins and transform faults, like in the 
Gulf of Mexico (Paull et al., 1984), Gulf of Cádiz (Pinheiro et al., 2003), the Chilean margin (Sellanes et al., 2004), Gulf of Guinea (Ondréas et al., 2005), and even the Antarctic (Domack et al., 2005).

Whale falls as well as wood falls (i. e. tree trunks, sunken ships) have recently been included as part of the reduced environments found in the deep-sea ocean, since it has been found that they also harbor their own chemosynthetic community (Smith et al., 1989; Smith \& Baco, 2003; Bienhold et al., 2013; Kalenitchenko et al., 2015). The slow decay of these organic-rich features and its active degradation by certain microorganisms, originates reduced compounds (primarily sulfide) (Tunnicliffe et al., 2003). The active degradation of organics consume the local oxygen and create anaerobic conditions optimal for sulfate-reducers, which ultimately provide also sulfide to the ecosystem (Tunnicliffe et al., 2003; Bienhold et al., 2013; Cunha et al., 2013a).

\subsubsection{Serpentinization and the origin of life}

It is suspected that the origin of life occurred 3.6 - $4 \mathrm{Ga}$ (billion years) ago (Seckbach et al., 2004), although no consistent evidences have been found yet. Some of the most promising early fossils are Paleoarchean rocks (ca. 3.4 Ga old, Pilbara Craton, Australia) with sights of photoautotrophic and sulfate-reducing bacteria (Duda et al., 2016), and microbial ${ }^{13} \mathrm{C}$-depleted kerogen contained in a hydrothermal chert vein from ca. 3.5 Ga ago also from Pilbara Craton (Duda et al., 2018). Furthermore, biological approaches to determine the metabolism and physiology of the last universal common ancestor (LUCA) do not clarify whether it was thermophilic, anaerobic, used hydrogen and $\mathrm{CO}_{2}$ for energy and carbon fixation, and was also capable of nitrogen fixation (Weiss et al., 2016); or instead, LUCA was mesophilic and anaerobic, but the ancestors of both bacteria and archaea lived at high temperatures (Boussau et al., 2008). In 2000, a new hydrothermal vent field was found $30 \mathrm{~km}$ away from the Mid-Atlantic Ridge and $15 \mathrm{~km}$ away from the closest spreading center. It was called Lost City. Venting fluids were relatively moderate $\left(40-90^{\circ} \mathrm{C}\right)$ and alkaline $(\mathrm{pH} 9-11)($ Kelley et al., 2001). The existence of such a unique hydrothermal field was due to 
serpentinization. By this process, ultramafic rocks - major component of the early Earth - now $3-5 \mathrm{~km}$ below the ocean floor, mix with infiltrated seawater and some are transformed into serpentinite, producing $\mathrm{H}_{2}$-rich fluids, alkaline conditions and $\mathrm{Fe}$ Ni metals (Müntener, 2010 and references therein; Sousa et al., 2013). Interestingly, in a Fischer-Tropsch-type process (see McCollom et al., 1999) methane is produced from hydrogen and $\mathrm{CO}_{2}$, as observed in Lost City (Sousa et al., 2013). Furthermore, the high $\mathrm{pH}$ of the venting fluids may create a chemiosmotic potential with the more acidic surrounding water, acting also as a source of energy (Sousa et al., 2013; Sojo et al., 2016). Many studies speculate that these conditions may have caused the origin of the first biotic metabolism, such as methanogenesis or acetogenesis (Sousa et al., 2013; Weiss et al., 2016). In fact, microorganisms found in Lost City are mainly related to the methane cycle. Consequently, Lost City and other alkaline hydrothermal fields are of great importance for the scientific community, since they seem to be the modern models of early Earth. However, this is a highly debated field and new studies are already pointing the possibility of terrestrial hydrothermalism as the place holding life's origins (Djokic et al., 2017).

Nevertheless, hydrothermal vents and cold seeps are abundant and harbor clues about the kind of reactions that initiated the chemistry of life, i. e. methanogenesis and anaerobic oxidation of methane (Martin et al., 2008). They are reminiscent of the earliest microbial ecosystems on the Earth. Furthermore, cold seeps are useful sites to observe how live evolves in ecosystems sustained by chemosynthesis, since they are more stable and older than present hydrothermal vents. In fact, some worms at cold seeps are thought to be up to 200 years old (Bergquist et al., 2000).

\subsection{Chemosynthesis-based ecosystems}

Deep-sea areas where locally reduced environments occur, i.e. hydrothermal vents, cold seeps, whale falls and wood falls, are considered to act like oases of life in the deep-sea desert. They harbor specific communities of organisms which are able to live in a habitat with high pressure, low oxygen and even the absence of light, needed for photosynthetic primary producers to grow (Fig. 1). They are commonly named 
"extreme deep-sea environments". Unlike most ecosystems, the primary producers at these sites obtain energy and carbon by chemosynthesis. This process is used by chemoautotrophic bacteria and archaea to obtain energy by means of chemical reactions, necessary to fix organic carbon and produce organic matter to fuel the rest of organisms with usable nutrients (Jannasch, 1984; Jannasch \& Motll, 1985). The most common chemosynthetic reactions are sulfide oxidation, sulfate reduction, methane oxidation (aerobically and anaerobically), methanogenesis and iron oxidation. In a healthy ecosystem, primary producers are among all the most abundant organisms. They must maintain not only their own population, but also transfer energy to the next trophic levels (Odum \& Barrett, 1971). Interestingly, invertebrates like worms, mussels and clams, which are normally grouped in the "consumers" trophic levels (they feed on organic compounds), are in chemosynthetic-based ecosystems part of the primary producers. They have reduced guts or even lack of a digestive system and obtain instead their nutrients from chemosynthetic endosymbionts (Cavanaugh et al., 1981; 2006; Southward, 1989). Animals and microorganisms live in a stable symbiosis, in which microorganisms enjoy an optimal and protective niche with easy access to chemical compounds, and animals have constantly direct food supply from bacterial metabolism (Van Dover, 2000; Cavanaugh et al., 2006). Furthermore, their ability of acting as primary producers reduces the loss of energy that occurs from one trophic level to the next, becoming ecologically more efficient (Lindeman, 1942).

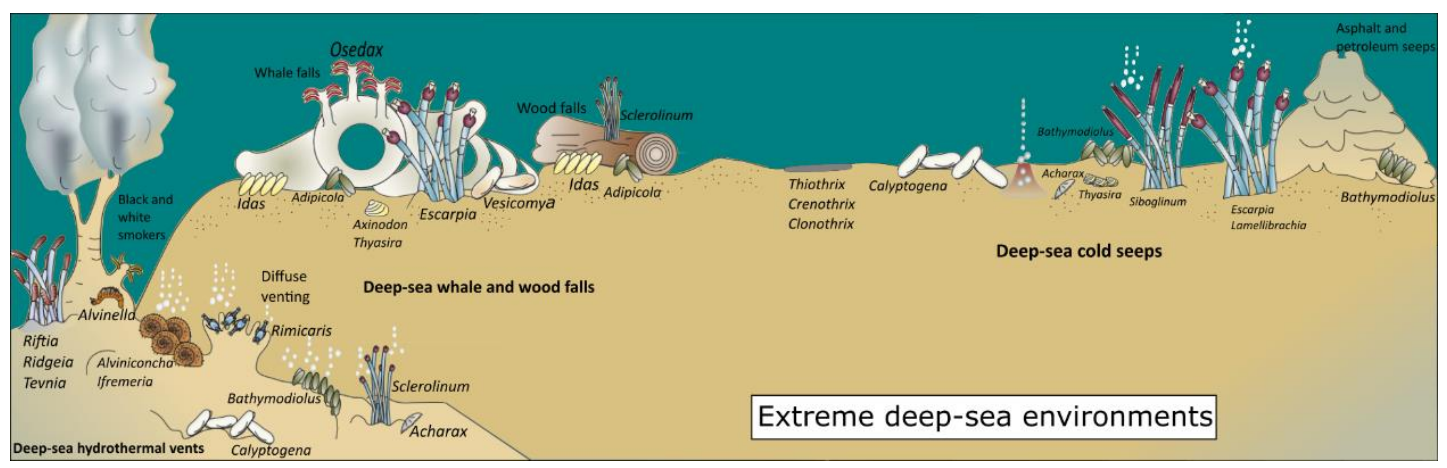

Figure 1: Scheme of the different extreme deep-sea environments found onto the seafloor. Noticed differences and similarities between the chemosynthetic communities of each environment. Modified from Dubilier et al., 2008. 
The way these animals acquire their chemosynthetic endosymbionts vary between hosts. Solemyidae and Vesicomyidae clams have been proposed to obtain their endosymbionts through vertical transmission via the gametes (Kleiner et al., 2012; Roeselers \& Newton, 2012), while each new generation of siboglinid tubeworms, bathymodiolin mussels and lucinid clams gain their endosymbionts from the environment through horizontal transmission (Hilário et al., 2011; Roeselers \& Newton, 2012). Horizontal acquisition of symbionts may be advantageous for the hosts, since they can adapt rapidly to the changing environment. Additionally, endosymbionts identified so far belong to the same clades of the Gammaproteobacteria (Cavanaugh et al., 2006; Roeselers \& Newton, 2012). This implies a specific selection of the host for the bacteria (and vice versa), although the mechanism how this happens is still unknown.

Chemosynthetic prokaryotes and eukaryotes are consequently well adapted to reduced deep-sea ecosystems. Yet, chemosynthetic organisms specialized on feeding on seeped fluids share habitat with non-chemosynthetic organisms, which become more abundant when seepage of fluids is decreasing (Levin et al., 2016). This implies a higher diversity and biomass of organisms related to these habitats, which means a major source of nutrients. Likewise, non-chemosynthetic organisms may also feed from nutrients falling from the photic zone above (besides the organics produced in situ), meaning an ecological interaction between different ecosystems. In fact, whale falls and wood falls were first part of the photosynthetic-based ecosystems. Thus, deep-sea ecosystems are not truly living oases and are indeed connected to upper layers other ecosystems (Levin et al., 2016).

\subsubsection{Sulfide oxidation}

The oxidation of reduced sulfur compounds like $\mathrm{H}_{2} \mathrm{~S}, \mathrm{~S}_{2} \mathrm{O}_{3}, \mathrm{~S}^{0}$ is widespread between prokaryotes from different environments, e. g. waste-water treatment plants, plants rhizosphere, garden soils, reduced-mud in shallow sea-water or reduced deep-sea environments (see Ghosh \& Dam, 2009 for a review). Due to the diversity of organisms, different pathways, mechanisms of electron transport and energy 
conservation are adapted to perform the oxidation of sulfur compounds (Ghosh \& Dam, 2009). In extreme deep-sea environments, organisms which are capable of sulfide oxidation belong the Gamma- (e.g. Thiohalophillus, Beggiatoa) and Epsilonproteobacteria (e.g. Sulfurimonas, Sulfurovum) (Wasmund et al., 2017). These bacteria are normally found forming dense bacterial mats on the sediment or living in symbiosis with invertebrates. In fact, it is the most stablished metabolism between all deep-sea chemosynthetic animals, i. e. Siboglinidae and Alvinellidae worms, Lucinidae, Solemyidae, Vesicomyidae and Mytilidae bivalves, and shrimps (Cavanaugh et al., 2006 and references therein), probably due to the abundance of reduced sulfur compounds in these environments and its good quality as source of energy. Since hosts are capable to migrate from oxic to anoxic zones or create nice fluxes of chemicals, bacteria living in symbiosis have advantage over free-living bacteria, which form biofilms when the oxic-anoxic interface is on the sediment, e. $g$. flux of reduced fluids from a cold seep is intense enough to rise this interface to the seafloor.

Two main pathways of sulfide oxidation may occur, i. e. the reverse sulfate reduction (Kappler \& Dahl, 2001) and the sulfur oxidation SOX multi-enzyme system (Friedrich et al., 2001). Molecular analysis revealed the use of the SOX pathway by Epsilonproteobacteria and free-living Gammaproteobacteria (Kleiner et al., 2012; Akermann et al., 2013), while endosymbionts (mostly Gammaproteobacteria) seem to prefer the reverse sulfate reduction pathway (Kleiner et al., 2012).

Reduced sulfur compounds - preferably hydrogen sulfide (Cavanaugh et al., 2006; Van Dover, 2000) - act as electron donors for phosphorylation, while oxygen (or nitrate in the absence of oxygen in some cases) acts as the electron acceptor. The energy produced in the form of ATP is then used to fix $\mathrm{CO}_{2}$. The Calvin cycle is the major pathway for carbon fixation. In deep-sea ecosystems, the Calvin cycle is mostly distributed along the Gammaproteobacteria, although endosymbionts from Riftia pachyptila can also fix carbon via the reverse tricarboxylic acid (rTCA) cycle (Kleiner et al., 2012). On the other hand, Epsilonproteobacteria use the rTCA cycle (Sievert et al., 2008 and references therein). Thus, sulfur availability defines the distribution and 
niche differentiation of sulfide-oxidizers (Sievert et al., 2008; Roeselers \& Newton, 2012). However, horizontal gen transfer between clades complicates phylogenetical differentiation (Kleiner et al., 2012).

\subsubsection{Anaerobic oxidation of methane}

The oxidation of methane driven anaerobically is considered the major sink of methane in marine settings (e. g. Valentine \& Reeburgh, 2000). The electron acceptors known until now to oxidize methane under these conditions are sulfate (Boetius et al., 2000), nitrate and nitrite (Raghoebarsing et al., 2006), and oxidized metals like manganese $\left(\mathrm{Mn}^{4+}\right)$ and iron $\left(\mathrm{Fe}^{3+}\right)$ (Beal et al., 2009). While anaerobic oxidation of methane (AOM) coupled to oxidized nitrogen compounds has been described to be most abundant in fresh water (Cui et al., 2015), AOM coupled to sulfate is best known for its role in deep-sea hydrothermal vents and cold seeps, where sulfate is the most abundant oxidized compound under anaerobic conditions (Orcutt et al., 2011). The role of iron and manganese in the oxidation of methane has been discovered more recently, and studies focusing on this issue point to its importance in reduced marine sediments at the continental margins, where these metals accumulate due to sea reach of rivers dragging these metals from land (Beal et al., 2009).

The anaerobic oxidation of methane in deep-sea ecosystems is classically thought to be a metabolism driven by a consortium of ANaerobic Methane oxidizing archaea (ANME, which actively oxidizes the methane) and Sulfate Reducing Bacteria (SRB, which provides sulfate as the electron acceptor) (Boetius et al., 2000; Valentine \& Reeburg, 2000; Blumenberg et al., 2004; Reitner et al., 2005b). This metabolism leads to the formation of authigenic carbonates and hydrogen sulfide (Peckmann et al., 2001; Reitner et al., 2005a; 2005b). Currently, four different clades of archaea have been related to sulfate-dependent AOM. i. e. ANME-1 (Hinrichs et al., 1999), ANME-2 (Orphan et al., 2001), ANME-3 (Niemann et al., 2006) and possibly GOM Arc I (Timmers et al., 2016). As SRB partners, different clades from the Deltaproteobacteria are coupled to ANME archaea and each clade seems to have preferences between the archaea (Cui et al., 2015). Although genes related to reverse methanogenesis have been identified in all groups - ANME-1 and ANME-2c harbor genes for a complete reverse methanogenic 
pathway (Cui et al., 2015; Krukenberg et al., 2018) — attempts to induce this metabolism have failed as it is not thermodynamically favorable for the microorganisms (Valentine \& Reeburgh, 2000; Cui et al., 2015; McGlynn, 2017). Furthermore, stable ${ }^{13} \mathrm{C}$ isotopes related to SRB have been found to be depleted, i. e. there must be a transfer of carbon between the archaea and the SRB (Thiel et al., 1999; Hinrichs et al., 1999). The production of acetate as an intermediate has been proposed for ANME-1 (Hallam et al., 2003; Meyerdierks, 2010) and for Candidatus Methanoperedens nitroreducens (previously known as ANME-2d; Haroon, et al., 2013). Additionally, many studies nowadays report the possibility of direct interspecies electron transfer* (DIET) as the mechanism used by ANME and SRB (e. g. McGlynn et al., 2015; Timmers et al., 2017), since high number of cytochromes have been found to be expressed in the membranes and genes encoding pili highly expressed (Krukenberg et al., 2018).

\section{*Direct interspecies electron transfer (DIET)}

It refers to a widely used symbiotic interaction in which electrons are freely transferred from microbial cell to another. These microorganisms normally express extracellular cytochromes and pili implied in the conduction of those electrons. By means of DIET microorganisms are able to perform metabolisms that could not be driven alone.

Moreover, dependency on SRB by ANME archaea have been proven not be necessary (Orphan et al., 2001; Knittel et al., 2005; Cui et al., 2015) and instead marine AOM can be coupled to a larger variety of oxidants (Beal et al., 2009; Knittel \& Boetius, 2009). A study performed by Beal et al. 2009 analyzed the preference of some organisms to consume certain oxidized compounds to metabolize methane anaerobically. The results demonstrated that ANME-2a and ANME-2c subgroups were prevalent in the presence of sulfate, and ANME-1 and ANME-3 may be capable of using oxidized manganese to perform AOM (see Figure S2 in Beal et al., 2009). 
Furthermore, AOM gained more energy coupled to reduction of metals than to sulfate reduction. Thus, the constant and active presence of sulfate-related AOM in the deepsea ocean may be due to the lack of metals available to be reduced, although microorganisms found in these areas are able to reduce metals, e. g. Desulfobulbus, Bacteriodes, Geobacter, Actinobacteria and Verrucomicrobia (Beal et al., 2009 and references therein). Likewise, some organisms may be even capable of perform AOM without the need of a microbial partner. For instance, the archaea $M$. nitroreducens can oxide methane by means of nitrate respiration (Haroon, et al., 2013), and ANME-2 have been decoupled from their SRB partners by adding ferric iron $\left(\mathrm{Fe}^{3+}\right)$ as soluble acceptor (Scheller et al., 2016).

Metals like iron and manganese must have played an important role in the early Earth for AOM-related organisms, since there was abundance of metals and absence of sulfate (Beal et al., 2009). Further studies are needed to understand better the AOM metabolism, considering the variability of metabolic pathways and implied organisms still to be discovered.

\subsubsection{Aerobic oxidation of methane}

Aerobic methane oxidation occurs ubiquitously in nature and in the oxic-anoxic interface where oxygen values are low but there is access to methane (Hanson \& Hanson, 1996; Pfluger et al., 2011). Therefore, methane not consumed by the AOM can be used by aerobic methanotrophic bacteria (Wrede et al., 2013). Methane is used as electron donor to produce energy, and as carbon source (Cavanaugh et al., 2006). To date, it is known that this metabolism is driven by bacteria from different clades, with diverse pathways to oxidize methane and morphotypes. They all have in common the presence of a methane monooxygenase, attached to the cytoplasmic membrane (pMMO) or free in the cytoplasm (sMMO), which makes them capable to metabolize methane into methanol. Methanol is used by other methylotrophic bacteria, but they differ from methanotrophs since they do not have MMO (Whittenbury \& Dalton, 1981). The methanol dehydrogenase (MDH) catalyzes then the oxidation of methanol to formaldehyde, which then is used for the carbon fixation. 
Group I methanotrophs belong to the Gammaproteobacteria and use the ribulose monophosphate pathway (RuMP) to fix carbon. Likewise, Group II methanotrophs are Alphaproteobacteria, which use the serine pathway. A recently identified group, Group III, are Verrucomicrobia capable of oxidizing methane and fixing carbon via the Calvin cycle (Kalyuzhnaya et al., 2015 and references therein). However, these are general characteristics and some bacteria may use other metabolisms than their relatives due to environmental adaptions via horizontal gene transfer (see Semrau et al., 2010 for a review).

Deep-sea environments happen to harbor mainly methanotrophic Gammaproteobacteria, probably by means of their effectivity in methane oxidation towards other aerobic methanotrophs and their quick response to shifts in methane levels (Petersen \& Dubilier, 2009; Semrau et al., 2010). Many methanotrophs, similar to sulfide-oxidizers, live in symbiosis with invertebrates, i. e. Cladorhizidae sponges, Mytildae mussels, Provannidae snails and Siboglinidae tubeworms (see Petersen \& Dubilier, 2009 for a review). They all happen in vents and cold seeps, since the levels of methane are higher in those habitats. However, methanotrophic Idas mussels have been also found in organic falls (Duperron et al., 2013). Hosts must be located close to the source of methane and provide a flux of oxygen to the symbionts, since diffusive flux of methane happens through host membranes, as there are not known host carrier proteins for methane (Nelson and Fisher, 1995; Petersen \& Dubilier, 2009).

Ruff et al. (2013) attempted to classify methylotrophic Gammaproteobacteria into three groups, i.e. Marine methylotrophic group-1 (MMG-1), -2 (MMG-2) and -3 (MMG-3). While MMG-1 and MMG-2 belong to the order Methylococcales, MMG3 are related to Methylophaga. MMG-1 and MMG-3 are related to chemosynthetic endosymbionts of marine invertebrates. Moreover, free-living methanotrophs are observed also in these sites, forming thick biofilms attached to the surface of tubes of some worms (in this study) or filamentous methanotrophs forming bacterial mats on the sediment, as Crenothrix and Clonothrix bacteria (Stoecker et al., 2006 and Vigliotta et al., 2007, respectively). 
Aerobic methane oxidation provides a high yield of energy and has a great impact in the food chain based on chemosynthetic primary producers (see Table 1 in Caldwell et al., 2008). Furthermore, compounds produced on the oxidation of methane, like methanol and $\mathrm{CO}_{2}$, act as elementary compounds needed as energy and carbon source for other organisms, e. g. methylotrophs, methanogens and sulfide-oxidizers (Paul et al., 2017).

\subsubsection{Methane production}

Methanogenesis is the process by which methane is produced biogenically. It is a type of anaerobic respiration, in which $\mathrm{CO}_{2}$ is reduced to $\mathrm{CH}_{4}$ by oxidizing $\mathrm{H}_{2}$ or other small molecules, like formate, acetate, methanol and methyl-containing C-1 molecules (Zeikus, 1977; Whitman et al., 2006). It yields low free energy, since from each $\mathrm{CO}_{2}$ reduced one molecule or less of ATP is produced (aerobic respiration produces 36 ATP molecules reducing $\mathrm{O}_{2}$ to $\mathrm{H}_{2} \mathrm{O}$ ) (Schink, 1997; Deppenmeier, 2002; Hoehler, 2004; Lyu et al., 2018). This metabolism sustains the live and growth of methanogenic archaea, which are the only microorganisms capable of producing methane on a large scale (e.g. Rother, 2010; Enzmann et al., 2018). Methanogens are strict anaerobic organisms, ubiquitously distributed in different anaerobic environments and normally related to the end of the anaerobic food chain of organic matter degradation, e. g. inside the rumen of animals, related to dead xylem tissue of plants, in sewage digesters, in anoxic seawater sediments related to continental margins, and in reduced deep-sea environments (e. g. Zeikus, 1977; Hoehler et al., 2010). However, at sites where abiotic $\mathrm{H}_{2}$ and $\mathrm{CO}_{2}$ levels are high, i. e. hydrothermal vents, methanogens are part of the chemosynthetic primary production core (Hoehler et al., 2010).

Methanogenic archaea were thought to belong only to the phylum Euryarchaeota, within the orders Methanococcales, Methanobacteriales, Methanosarcinales, Methanomicrobiales and Methanopyrales (see Enzmann et al. 2018 for a review). Recently, Bathyarchaeota and Verstraetearchaeota phyla have also been proposed to include methanogens (Evans et al. 2015 and Vanwonterghem et al. 2016, respectively), although limited information is still available. While most members of the 
Methanobacteriales and Methanococcales are obligate hydrogenotrophs, many members of the Methanosarcinales are also capable of using methyl-containing C-1 compounds or acetate (Whitman et al., 2006; Rother, 2010).

Hydrogenotrophic methanogenesis is the only methanogenic metabolism in which organic compounds $\left(\mathrm{CH}_{4}\right)$ are produced from inorganic compounds $\left(\mathrm{H}_{2}\right.$ and $\left.\mathrm{CO}_{2}\right)$, and therefore can be considered as chemosynthesis. Hydrothermal vents, hot springs and other sites related to volcanic activity and serpentinization, have high levels of $\mathrm{H}_{2}$ (and $\mathrm{CO}_{2}$ ), which is normally a limiting factor for hydrogenotrophic methanogenesis (e.g. Ver Eecke et al., 2012). Furthermore, fossil records of methanogenic metabolism date from 3.5 Ga ago (Ueno et al., 2006), which leads to the assumption of methanogenesis to be one of the first metabolisms on Earth (Martin et al., 2016).

Despite the plasticity they have evolved along all these years, the distribution of these methanogens is now limited, since the modern biosphere is rich in oxygen and sulfate. While oxygen is toxic for the cells and inhibits many of the proteins involved the production of methane and biomass (Xing \& Whitman, 1987; Whitman, 2006), sulfatereducers also consume $\mathrm{H}_{2}$ and outcompete the methanogens than rely only in $\mathrm{H}_{2}$ are electron donor (Jing et al., 2016; Nobu et al., 2016). Nowadays, methanogenesis is intensively under study due to its widely used in industry and probably future alternative for fossil fuels (e. g. Enzmann et al., 2018).

\subsection{Aim of the study}

This study aims at unraveling the importance of symbiotic adaptations of prokaryotic microorganisms in extreme deep-sea environments. For this purpose, we have characterized and analyzed the microbial communities related to different mud volcanoes from the Gulf of Cádiz. Multidisciplinary procedures have been used to approach this issue, since symbiosis implies ecological interactions and thus a complete knowledge of the variables affecting those interactions is needed. We have used data collected from seismic and bathymetric analysis, measurements of water variables, microscopic observations, stable isotopic analyses, biomarker analyses and environmental DNA analyses. These data are then compared with data from other 
studies to ultimately understand the role of symbiosis in extreme deep-sea environments. Furthermore, these environments can be used as models of the early biosphere, giving an opportunity to speculate the role of symbiosis in early life and evolution.

\subsubsection{Gulf of Cádiz}

The Gulf of Cádiz is an area located between southwest Spain, south Portugal and northeast Morocco (Fig. 2). It is characterized by the abundances of fluid flow features (i. e. pockmarks and mud volcanoes) due to the hydrocarbon-rich reservoirs and highly tectonic activity of the region (Medialdea et al., 2009). Cold-seep related fauna is normally found in these mud volcanoes since hydrocarbon-rich fluids are emitted normally in dripping-like seeps and fauna do not die due to eruptions. For instance, chemosynthetic invertebrates, such as Siboglinidae worms and a variability of bivalve's species have been extensively described distributed between the mud volcanoes of the Gulf of Cádiz (e. g. Rueda et al., 2012; Cunha et al., 2013b; Rodrigues et al., 2013). These chemosynthetic-based communities may die due to volcanic inactivity - leading to the colonization of non-chemosynthetic communities - or to episodes of mud-breccia flows. Likewise, authigenic carbonates (methane-derived carbonates), pockmarks and brine lakes are normally found in mud volcanoes (León et al., 2012). Mud volcanoes are of great interest for the scientific community due to their widespread occurrence, their strong relationship with hydrocarbons emission and potential influence in climate change. The field of mud volcanoes in the Gulf of Cádiz (Ivanov et al., 2000) and the Haakon Mosby Mud Volcano in the Norwegian margin (Pimenov, 2000) are the best studied areas, but mud volcanoes are also found eastern Mediterranean Sea or even on the terrestrial surface, like in Italy, Romania and Azerbaijan (see Etiope et al., 2009 for a review).

For this study, mud volcanoes from the Moroccan margin (i. e. Bonjardim MV, El Cid MV and Al Gacel MV) and northern Iberian margin (i. e. Hespérides MV and Anastasya MV) have been sampled onboard the R/V Sarmiento de Gamboa and R/V Celtic Explorer, respectively (Fig. 2). 


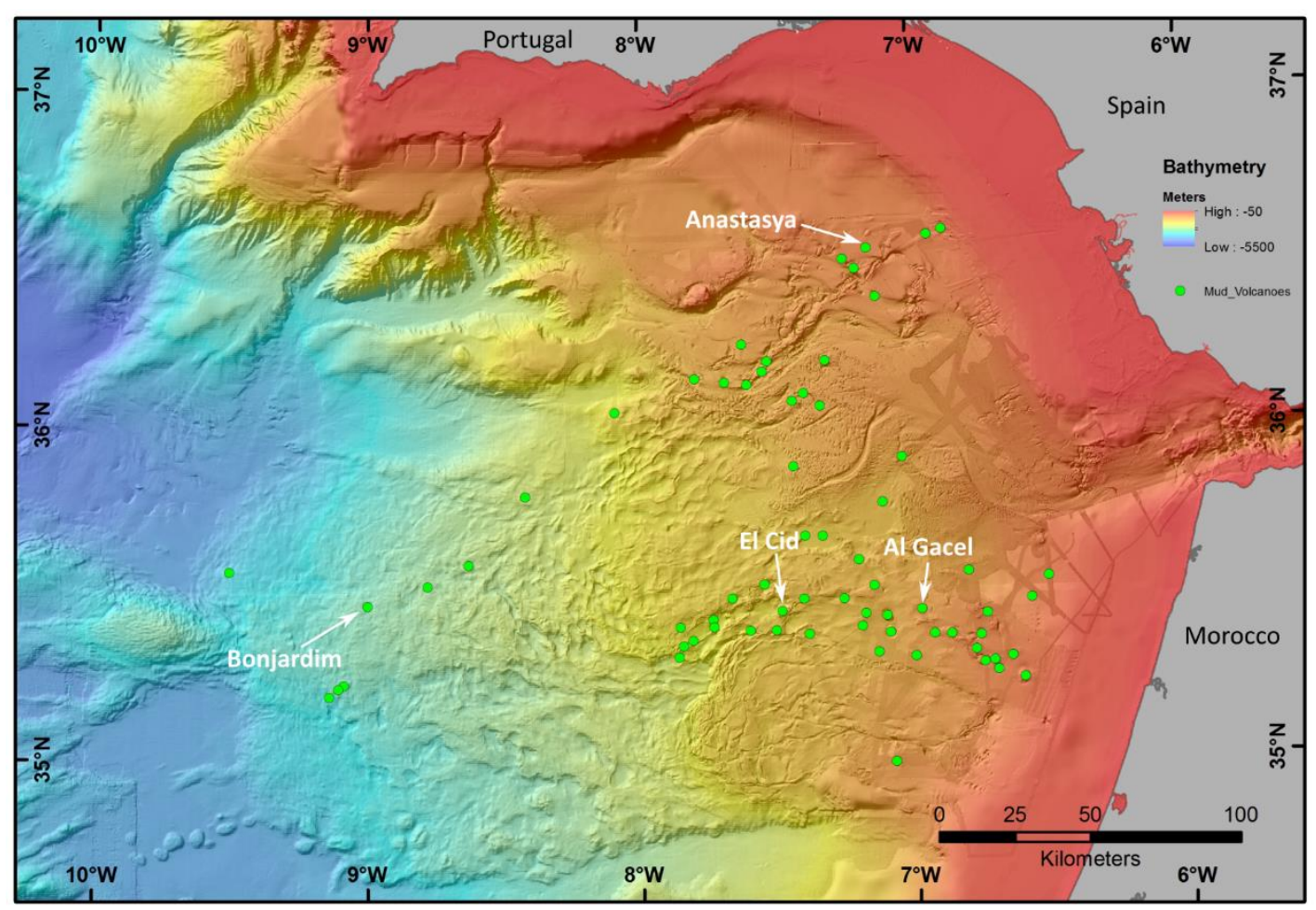

Figure 2: Overview of the mud volcanoes discovered to date in the Gulf of Cádiz. El Cid MV, Bonjardim MV, Al Gacel MV and Anastasya MV are the mud volcanoes used for this study. Modified from Somoza et al., 2018.

\subsection{References}

Akermann, N. H., Butterfield, D. A., and Huber, J. A.: Phylogenetic diversity and functional gene patterns of sulfur-oxidizing subseafloor Epsilonproteobacteria in diffuse hydrothermal vent fluids, Front. Microbiol., 4(185), 1-14, 2013.

Ballard, R. D.: Notes on a Major Oceanographic Find (marine animals near hot-water vents at ocean bottom), Oceanus, 20, 35-44, 1977.

Beal, E. J., House, C. H., and Orphan, V. J.: Manganese- and iron-dependent marine methane oxidation, Science, 325, 184-187, 2009.

Bergquist, D. C., Williams, F. M. and Fisher, C. R.: Longevity record for deep-sea invertebrate, Nature, 403, 499-500, 2000.

Bienhold, C., Ristova, P. P., Wenzhöfer, F., Dittmar, T., and Boetius, A.: How DeepSea Wood Falls Sustain Chemosynthetic Life, PLoS ONE, 8(1), 2013. 
Blumenberg, M., Seifert, R., Reitner, J., Pape, T., and Michaelis, W.: Membrane lipid patterns typify distinct anaerobic methanotrophic consortia, PNAS, 101(30), 11111-11116, 2004.

Boetius, A., Ravenschlag, K., Schubert, C. J., Rickert, D., Widdel, F., Gieseke, A., Amann, R., Jørgensen, B. B., Witte, U., and Pfannkuche, O.: A marine microbial consortium apparently mediating anaerobic oxidation of methane, Nature, 407, 623-626, 2000.

Boussau, B., Blanquart, S., Necsulea, A., Lartillot, N., and Gouy, M.: Parallel adaptations to high temperatures in the Archaean eon, Nature, 456(7224), 942945, 2008.

Caldwell, S. L., Laidler, J. R., Brewer, E. A., Eberly, J. O., Sandborgh, S. C., and Colwell, F. S.: Anaerobic oxidation of methane: mechanisms, bioenergetics, and the ecology of associated microorganisms. Environ. Sci. Tech., 42(18), 6791-6799, 2008.

Cavanaguh, C. M., Gardiner, S. L., Jones, M. L., Jannasch, H. W., and Waterbury, J. B.: Prokaryotic cells in the hydrothermal vent tube worm Riftia pachyptila Jones: possible chemoautotrophic symbionts, Science, 213(4505), 340-342, 1981.

Cavanaugh, C. M., MCkiness, Z. P., Newton, I. L. G., and Stewart, F. J.: Marine chemosynthetic symbioses, Prokaryotes, 1, 475-507, 2006.

Cui, M., Ma, A., Qi, H., Zhuang, X., and Zhuang, G.: Anaerobic oxidation of methane: an "active" microbial process, MicrobiologyOpen, 4(1), 1-11, 2015.

Cunha, M. R., Matos, F. L., Génio, L., Hilário, A., Moura, C. J., Ravara, A., and Rodrigues, C. F.: Are Organic Falls Bridging Reduced Environments in the Deep Sea? - Results from Colonization Experiments in the Gulf of Cádiz, PLoS ONE, 8(10), 2013a.

Cunha, M. R., Rodrigues, C. F., Génio, L., Hilário, A., Ravara, A., and Pfannkuche, O.: Macrofaunal assemblages from mud volcanoes in the Gulf of Cadiz: abundance, biodiversity and diversity partitioning across spatial scales, Biogeosciences, 10, 2553-2568, $2013 \mathrm{~b}$. 
De Bary, A.: Die Erscheinung der Symbiose, Verlag von Karl, J., Trübner, Strassburg, 1879.

Denison, R. F., and Kiers, E. T.: Life histories of symbiotic rhizobia and mycorrhizal fungi, Curr. Biol., 21, R775-R785, 2011.

Deppenmeier, U.: Redox-driven proton translocation in methanogenic Archaea, Cell. Mol. Life Sci., 59, 1513-1533, 2002.

Djokic, T., Van Kranendonk, M. J., Campbell, K. A., Walter, M. R., and Ward, C. R.: Earliest signs of life on land preserved in ca. $3.5 \mathrm{Ga}$ hot spring deposits, Nat. Commun., 8, 15263, 2017.

Domarck, E., Ishman, S., Leventer, A., Sylva, V. W., and Huber, B.: A chemotrophic ecosystem found beneath Antarctic ice shelf, Eos, 86 (29), 269-276, 2005.

Douglas, A. E., and Werren, J. H.: Holes in the Hologenome: Why Host-Microbe Symbioses Are Not Holobionts, mBio, 7(2), e02099, 2016.

Dubilier, N., Bergin, C., and Lott, C.: Symbiotic diversity in marine animals: the art of harnessing chemosynthesis, Nat. Rev. Microbiol., 6, 725-740, 2008.

Duda, J.-P., Thiel, V., Bauersachs, T., Missbach, H., Reinhardt, M., Schäfer, N., Van Kranendonk, M. J., and Reitner, J.: Ideas and perspectives: hydrothermally driven redistribution and sequestration of early Archaean biomass - the "hydrothermal pump hypothesis", Biogeosciences, 15(5), 1535-1548, 2018.

Duda, J.-P., Van Kranendonk, M. J., Thiel, V., Ionescu, D., Strauss, H., Schäfer, N., and Reitner, J.: A Rare Glimpse of Paleoarchean Life: Geobiology of an Exceptionally Preserved Microbial Mat Facies from the 3.4 Ga Strelley Pool Formation, Western Australia, PLOS One, 11(1), e0147629, 2016.

Dunn, D. F.: The clownish sea anemones: Stichodactylidae (Coelenterate: Actiniaria) and other sea anemones symbiotic with pomacentrid fishes, Trans. Am. Phil. Soc., 71(1), 3-115, 1981.

Duperron, S., Gaudron, S. M., Rodrigues, C. F., Cunha, M. R., Decker, C., and Olu, K.: An overview of chemosynthetic symbioses in bivalves from the North Atlantic and Mediterranean Sea, Biogeosciences, 10, 3241-3267, 2013. 
Enzmann, F., Mayer, F., Rother, M, and Holtmann, D.: Methanogens: biochemical background and biotechnological applications, AMB Expr., 8(1), 1-22, 2018.

Etiope, G., Feyzullayev, A., and Baciu, C. L.: Terrestrial methane seeps and mud volcanoes: A global perspective of gas origin, Petrol. Geol., 26(3), 333-344, 2009.

Evans, P. N., Parks, D. H., Chadwick, G. L., Robbins, S. J., Orphan, V. J., Golding, S. D., and Tyson, G. W.: Methane metabolism in the archaeal phylum Bathyarchaeota revealed by genome-centric metagenomics, Science, 350, 434438, 2015.

Friedrich, C. G., Rother, D., Quentmeier, A., Fischer, J., and Bardischewsky, F.: Oxidation of reduced inorganic sulfur compounds by bacteria: emergence of a common mechanism?, Appl. Environ. Microbiol., 67, 2873-2880, 2001.

Ghosh, W., and Dam, B.: Biochemistry and molecular biology of lithotrophic sulfur oxidation by taxonomically and ecologically diverse bacteria and archaea, FEMS Microbiol. Rev., 33, 999-1043, 2009.

Hallam, S. J., Girguis, P. R., Preston, C. M., Richardson, O. M., and DeLong, E. F.: Identification of methyl coenzyme $\mathrm{M}$ reductase $\mathrm{A}$ (mcrA) genes associated with methane-oxidizing archaea, Appl. Environ. Microbiol., 69, 5483-5491, 2003.

Hallman, C.: Steroid biomarkers throughout the Precambrian yield a fresh look on eukaryotic evolution, in: Dating the Origin of Life: Present-Day Molecules and First Fossil Record, Reitner, J., Fritz, H.-J., and Duda, J.-P. (eds.), Symposium Abstract, Göttingen, 15, 2014.

Hanson, R. S., and Hanson, T. E.: Methanotrophic bacteria, Microbiol. Rev., 60(2), 439-471, 1996.

Haroon M. F., Hu, S., Shi, Y., Imelfort, M., Keller, J., Hugenholtz, P., Yuan, Z., and Tyson, G. W.: Anaerobic oxidation of methane coupled to nitrate reduction in a novel archaeal lineage, Nature, 501, 1-7, 2013.

Haymon, R. M., Fornari, D. J., Edwards, M. H., Carbotte, S., Wright, D., and Macdonald, K. C.: Hydrothermal vent distribution along the East Pacific Rise 
crest $\left(9^{\circ} 09^{\prime}-54^{\prime} \mathrm{N}\right)$ and its relationship to magmatic and tectonic processes on fast-spreading mid-ocean ridges, Earth Planet. Sc. Lett., 104, 513-534, 1991. Hilário, A., Capa. M., Dahlgren, T. G., Halanych, K. M., Little, C. T. S., Thornhill, D. J., Verna, C., and Glover, A. G.: New Perspectives on the Ecology and Evolution of Siboglinid Tubeworms, PLoS ONE, 6(2), e16309, 2011.

Hinrichs, K.-U., Hayes, J. M., Sylva, S. P., Brewer, P. G., and DeLong, E. F.: Methaneconsuming archaebacteria in marine sediments, Nature, 398, 802-805, 1999.

Hoehler, T.: Biological energy requirements as quantitative boundary conditions for life in the sub- surface, Geobiology, 2(4), 205-215, 2004.

Hoehler, T. Gunsalus, R. P., and McInerney, M J.: Environmental Constraints that Limit Methanogenesis, in: Handbook of hydrocarbon and lipid microbiology, Timmis, K., (Ed.), Springer, Germany, 635-654, 2010.

Ivanov, M. K., Kenyon, N., Nielsen, T., Wheeler, A., Monteiro, H., Gardner, J., Comas, M., Akhmanov, A., and Akhmetzhanov, G.: Goals and principal results of the TTR-9 cruise. IOC/UNESCO Worksh. Rep., 168, 3-4, 2000.

Jannasch, H. W.: Chemosynthesis - the nutritional basis for life at deep-sea vents, Oceanus, 27(3), 73-78, 1984.

Jannasch, H. W., and Mottl, M. J.: Geomicrobiology of deep-sea hydrothermal vents, Science, 229 (4715), 717-725, 1985.

Jing, H., Cheung, S., Zhou, Z., Wu, C., Nagarajan, S., and Liu, H.: Spatial Variations of the Methanogenic Communities in the Sediments of Tropical Mangroves, PLoS ONE, 11(9), 1-18, 2016.

Jones, M. L.: Riftia pachyptila Jones: observations on the vestimentiferan worm from the Galapagos Rift, Science, 213(4505), 333-336, 1981.

Kalyuzhnaya, M. G., Puri, A. W., and Lidstrom, M. E.: Metabolic engineering in methanotrophic bacteria, Metab. Eng., 29, 142-152, 2015.

Kappler, U., and Dahl, C.: Enzymology and molecular biology of prokaryotic sulfite oxidation, FEMS Microbiol. Lett., 203, 1-9, 2001.

Kalenitchenko, D. Fagervold, S. K., Pruski, A. M., Vétion, G., Yücel, M., Le Bris, N., and Galand, P. E.: Temporal and spatial constraints on community assembly 
during microbial colonization of wood in seawater, ISME J., 9, 2657-2670, 2015.

Kelley, D. S., Karson, J. A., Blackman, D. K., Früh-Green, G. L., Butterfield, D. A., Lilley, M. D., Olson, E. J., Schrenk, M. O., Roe, K. K., Lebon, G. T., Rivizzigno, P., and the AT-60 Shipboard Party: An off-axis hydrothermal vent field near the Mid-Atlantic Ridge at 30 N, Nature, 412, 145-149, 2001.

Kiers, E. T., and West, S. A.: Evolving new organisms via symbiosis, Science, 348(6233), 392-394, 2015.

Kleiner, M., Petersen, J., and Dubilier, N.: Convergent and divergent evolution of metabolism in sulfur-oxidizing symbionts and the role of horizontal gene transfer, Curr. Opin. Microbiol., 15(5), 621-631, 2012.

Knittel, K., Lösekann, T., Boetius, A., Kort, R., Amann, R.: Diversity and distribution of methanotrophic archaea at cold seeps, Appl. Environ. Microbiol., 71(1), 467-479, 2005.

Knittel, K., and Boetius, A.: Anaerobic oxidation of methane: progress with an unknown process, Annu. Rev. Microbiol., 63, 311-334, 2009.

Koonin, E. V.: Origin of eukaryotes from within archaea, archaeal eukaryome and burst of gene gain: eukaryogenesis just made easier?, Philos. Trans. R. Soc. Lond. B. Biol. Sci., 370(1678), 1-12, 2015.

Krukenberg, V., Riedel, D., Gruber-Vodicka, H. R., Buttigieg, P. L., Tegetmeyer, H. E., Boetius, A., and Wegener, G.: Gene expression and ultrastructure of mesoand thermophilic methanotrophic consortia, Environ. Microbiol., 20(5), 16511666, 2018.

Larsbrink, J., Rogers, T. E., Hemsworth, G. R., McKee, L. S., Tauzin, A. S., Spadiut, O., Klinter, S., Pudlo, N. A., Urs, K., Koropatkin, N. M., Creagh, A. L., Haynes, C. A., Kelly, A. G., Cederholm, S. N., Davies, G. J., Martens, E. C., and Brumer, H.: A discrete genetic locus confers xyloglucan metabolism in select human gut Bacteroidetes, Nature, 506, 498-502, 2014.

León, R., Somoza, L., Medialdea, T., Vázquez, J. T., González, F. J., López-González, N., Casas, D., Mata, M. P., Fernández-Puga, M. C., Giménez-Moreno, C. J., 
and Díaz-del-Río, V.: New discoveries of mud volcanoes on the Moroccan Atlantic continental margin (Gulf of Cádiz): morpho-structural characterization, Geo-Mar. Lett., 32, 473-488, 2012.

Levin, L. A.: Ecology of Cold Seep Sediments: Interactions of Fauna with Flow, Chemistry and Microbes, in: Ocenography and Marine Biology, Gibson, R. N., Atkinson, E. J. A, and Gordon, J. D. M. (eds.), CRC Press, 11-56, 2005.

Levin, L. A, Baco, M. A., Bowden, D. A, Colaco, A., Cordes, E. E., Cunha, M. R., Demopoulos, A. W. J., Gobin, J., Grupe, B. M., Le, J., Metaxas, A., Netburn, A. N., Rouse, G. W., Thurber, A. R., Tunnicliffe, V., Van Dover, C. L., Vanreusel, A., and Watling, L.: Hydrothermal vents and methane seeps: rethinking the sphere of influence, Front. Mar. Sci., 3(72), 1-23, 2016.

Lindeman, R. L.: The trophic-dynamic aspect of ecology, Ecology, 32, 399-418, 1942.

Lonsdale, P.: Deep-tow observations at the mounds abyssal hydrothermal field, Galapagos Rift, Earth and Planetary Science Letters, 36(1), 92-110, 1977.

López-García, P., and Moreira, D.: López-García, P., \& Moreira, D. (2015). Open Questions on the Origin of Eukaryotes. Trends Ecol. Evol., 30(11), 697-708, 2015.

Lyu, Z., Shao, N., Akinyemi, T., and Whitman, W. B.: Methanogenesis, Curr. Biol., 28, R727-R732, 2018.

Margulis, L. and Fester, R. (Eds.): Symbiosis as a source of evolutionary innovation, MIT Press, 470, 1991.

Martin, W. F., Baross, J., Kelley, D., and Russell, M. J.: Hydrothermal vents and the origin of life, Nature Reviews Microbiology, 6(11), 805-814, 2008.

Martin, W. F., Weiss, M. C., Neukirchen, S., Nelson-Sathi, S., and Sousa, F. L.: Physiology, phylogeny, and LUCA, Microb. Cell, 3(12), 582-587, 2016.

Martin, B. D., and Schwab, E.: Symbiosis: "living together" in chaos, Stud. Hist. Biol., 4(4), 7-25, 2012.

McCollom, T. M., Ritter. G., and Simoneit, B. R. T.: Lipid synthesis under hydrothermal conditions by Fischer-Tropsch-type reactions, Orig. Life Evol. Biosph., 29, 153-166, 1999. 
McGlynn, S. E., Chadwick, G. L., Kempes, C. P., and Orphan, V. J.: Single cell activity reveals direct electron transfer in methanotrophic consortia, Nature, 526(7574), 531-535, 2015.

McGlynn, S. E.: Energy Metabolism during Anaerobic Methane Oxidation in ANME Archaea, Microbes Environ., 32(1), 5-13, 2017.

Medialdea, T., Somoza, L., Pinheiro, L. M., Fernández-Puga, M. C., Vázquez, J. T., León, R., Ivanov, M. K., Magalhães, V., Díaz-del-Río, V., and Vegas, R.: Tectonics and mud volcano development in the Gulf of Cádiz, Mar. Geol., 261, 48-63, 2009.

Meyerdierks, A., Kube, M., Kostadinov, I., Teeling, H., Glöckner, F. O., Reinhardt, R., and Amann, R.: Metagenome and mRNA expression analyses of anaerobic methanotrophic archaea of the ANME-1 group, Environ. Microbiol., 12(2), 422-439, 2010.

Müntener, O.: Serpentine and serpentinization: A link between planet formation and life, Geology, 38(10), 954-960, 2010.

Muscatine, L. and Lenhoff, H. M.: Symbiosis: on the role of algae symbiotic with hydra, Science, 142(3594), 956-958, 1963.

Nakazawa, H.: What is the ultimate ancestor? Evidence from fossils and genes analyses, in: Darwinian Evolution of Molecules, Advances in Geological Science, Springer, Singapore, 31-54, 2018.

Nelson, K., and Fisher, C. R.: Chemoautotrophic and methanotrophic endosymbiotic bacteria at deep-sea vents and seeps, in: The Microbiology of Deep-Sea Hydrothermal Vents, Karl, D.M. (Ed.), USA: CRC Press, USA, 125-167, 1995.

Niemann, H., Duarte, J., Hensen, C., Omoregie, E., Magalhães, V. H., Elvert, M., Pinhiero, L. M., Kopf, A., and Boetius, A.: Microbial methane turnover at mud volcanoes of the Gulf of Cadiz, Geochim. Cosmochim. Ac., 70(21), 5336-5355, 2006.

Nobu, M.K., Narihiro, T., Kuroda, K., Mei, R., and Liu, W.-T.: Chasing the elusive Euryarchaeota class WSA2: genomes reveal a uniquely fastidious methylreducing methanogen, ISME J., 10, 2478-2487, 2016. 
Odum, E. P., and Barrett, G. W. (Eds.): Fundamentals of Ecology, Third Edition, W.B. Saunders Company, Philadelphia, 1971.

Ondréas, H., Olu, K., Fouquet, Y., Charlou, J. L., Gay, A., Dennielou, B., Donval, J. P., Fifis, A., Nadalig, T., Cochonat, P., Cauquil, E., Bourillet, J. F., Le Moigne, M., and Sibuet, M.: ROV study of a giant pockmark on the Gabon continental margin, Geo-Mar. Lett., 25(5), 281-292, 2005.

Orcutt, B. N., Sylvan, J. B., Knab, N. J., and Edwards, K. J.: Microbial Ecology of the Dark Ocean above, at, and below the Seafloor, Microbiol. Mol. Biol. R., 75(2), 361-422, 2011.

Orphan, V. J., Hinrichs, K.-U., Ussler III, W., Paull, C. K., Taulor, L. T., Sylva, S. P., Hayes, J. M., and DeLong, E. F.: Comparative Analysis of Methane-Oxidizing Archaea and Sulfate-Reducing Bacteria in Anoxic Marine Sediments, Appl. Environ. Microb., 67, 1922-1934, 2001.

Oulhen, N., Schulz, B. J., and Carrier, T. J.: English translation of Heinrich Anton de Bary's 1878 speech, 'Die Erscheinung der Symbiose' ('De la symbiose'), Symbiosis, 69(3), 131-139, 2016.

Paul, B. G., Ding, H., Bagby, S. C., Kellermann, M. Y., Redmond, M. C., Andersen, G. L., and Valentine, D. L.: Methane-Oxidizing Bacteria Shunt Carbon to Microbial Mats at a Marine Hydrocarbon Seep, Front. Microbiol., 8(186), 113, 2017.

Paull, C. K., Commeau, R., Freeman-Lynde, R. P., Neumann, C., Corso, W. P., Golubic, S., Hook, J. E., Sikes, E., and Curray, J.: Biological Communities at the Florida Escarpment Resemble Hydrothermal Vent Taxa, Science, 226, 965-967, 1984.

Peckmann, J., Reimer, A., Luth, U., Luth, C., Hansen, B.T., Heinicke, C., Hoefs, J., and Reitner, J.: Methane-derived carbonates and authigenic pyrite from the northwestern Black Sea, Mar. Geol., 177, 129-150, 2001.

Petersen, J. M., and Dubilier, N.: Methanotrophic symbioses in marine invertebrates, Environ. Microbiol. Rep., 1(5), 319-335, 2009. 
Pfluger, A. R., Wu, W.-M., Pieja, A. J., Wan, J., Rostkowski, K. H., and Criddle, C. S.: Selection of Type I and Type II methanotrophic proteobacteria in a fluidized bed reactor under non-sterile conditions, Bioresource Technol., 102, 99199926, 2011.

Pimenov, N. V.: Microbiological Processes of the Carbon and Sulfur Cycles at Cold Methane Seeps of the North Atlantic, Microbiology, 69(6), 709-720, 2000.

Pinheiro, L. M., Ivanov, M. K., Sautkin, A., Akhmanov, G., Magalhães, V. H., Volkonskaya, A., Monteiro, J. H., Somoza, L., Gardner, J., Hamouni, N., and Cunha, M. R.: Mud volcanism in the Gulf of Cádiz: results from the TTR-10 cruise, Mar. Geol., 195, 131-151, 2003.

Raghoebarsing, A., Pol, A., Van de Pas-Schoonen, K. T., Smolders, A. J. P., Ettwig, K. F., Rijpstra, I. C., Schouten, S., Sinninghe Damsté, J. S., Op den Camp, H. J. M., Jetten, M. S. M., and Strous, M.: A microbial consortium couples anaerobic methane oxidation to nitrification, Nature, 440, 918-921, 2006.

Reitner, J., Peckmann, J., Blumenberg, M., Michaelis, W., Reimer, A., and Thiel, V.: Concretionary methane-seep carbonates and associated microbial communities in Black Sea sediments, Palaeogeogr., Palaeoclimatol., Palaeocl., 227, 18-30, 2005a.

Reitner, J., Peckmann, J., Reimer, A., Schumann, G., and Thiel, V.: Methane-derived carbonate build-ups and associated microbial communities at cold seeps on the lower Crimean shelf (Black Sea), Facies, 51, 66-79, 2005 b.

Rodrigues, C. F., Hilário, A., and Cunha, M. R.: Chemosymbiotic species from the Gulf of Cadiz (NE Atlantic): distribution, life styles and nutritional patterns, Biogeosciences, 10, 2569-2581, 2013.

Roeselers, G., and Newton, I. L. G.: On the evolutionary ecology of symbioses between chemosynthetic bacteria and bivalves, Appl. Microbiol. Biotechnol., 94, 1-10, 2012.

Rona, P. A., Klinkhammer, G., Nelsen, T. A., Trefry, J. H., and Elderfield, H.: Black smokers, massive sulphides and vent biota at the Mid-Atlantic Ridge, Nature, 321(6065), 33-37, 1986. 
Rother, M: Methanogenesis, in: Handbook of hydrocarbon and lipid microbiology, Timmis, K., (Ed.), Springer, Germany, 483-499, 2010.

Rueda, J. L., González-García, E., Marina, P., Oporto, T., Rittierott, C., LópezGonzález, N., Faria, C., Moreira, J., López, E., Megina, C., López-González, P. J., García Raso, J. E., Gofas, S., Salas, C., Bruque, G., López, F. J., Vázquez, J. T., Fernández-Salas, L. M., and Díaz-del-Río, V.: Biodiversity and geodiversity in the mud volcano field of the Spanish margin (Gulf of Cádiz), MIA Symposium, 2012.

Ruff, S. E., Arnds, J., Knittel, K., Amann, R., Wegener, G., Ramette, A., and Boetius, A.: Microbial Communities of Deep-Sea Methane Seeps at Hikurangi Continental Margin (New Zealand), PLoS ONE, 8(9), 1-16, 2013.

Sagan (Margulis), L.: On the origin of mitosing cells, J. Theoret. Biol., 14, 225-274, 1967.

Scheller, S., Yu, H., Chadwick, G. L., McGlynn, S. E., and Orphan, V. J.: Artifical electron decouple archaeal methane oxidation from sulfate reduction, Science, 351(6274), 703-707, 2016.

Schink, B.: Energetics of syntrophic cooperation in methanogenic degradation, Microbiol. Mol. Biol. Rev., 61(2), 262-280, 1997.

Sechbach, J., Chela-Flores, J., Owen, T., and Raulin, F. (eds.): Life in the Universe. From the Miller Experiment to the Search for Life in other Worlds, Springer, Dordrecht, 387 pp., 2004.

Sellanes, J., Quiroga, E., and Gallardo, V. A.: First direct evidence of methane seepage and associated chemoynthetic communities in the bathyal zone off Chile, J. Mar. Biol. Assoc. UK, 84 (5), 1065-1066, 2004.

Semrau, J. D., DiSpirito, A. A., Yoon, S.: Methanotrophs and copper, FEMS Microbiol. Rev., 34(4), 496-531, 2010.

Sievert, S. M., Hügler, M., Taylow, C. D., and Wirsen, C. O.: Sulfur oxidation at deepsea hydrothermal vents, in: Microbial sulfur metabolism, Dahl, C., and Friedrich, C. G. (Eds.), Springer, Germany, 238-258, 2008. 
Smith C. R., and Baco A.: Ecology of whale falls at the deep-sea floor, Oceanogr. Mar. Biol., 41, 311-354, 2003.

Smith, C. R., Kukert, H., Wheatcroft, R. A., Jumars, P. A. and Deming, J. W.: Vent fauna on whale remains, Nature, 34, 27-128, 1989.

Sojo, V., Herschy, B., Whicher, A., Camprubí, E., and Lane, N.: The origin of life in alkaline hydrothermal vents, Astrobiology, 16(2), 181-197, 2016.

Somoza, L., Medialdea, T., Terrinha, O., Pinheiro, L., Magalhes, V., González, F. J., León, R., Batista, L., and Lobato, A.: Catalogue of gas seeps around the Iberian continental margin: Atlantic vs. Mediterranean, GIMS 14 Conference, 2018.

Sousa, F. L., Thiergart, T., Landan, G., Nelson-Sathi, S., Pereira, I. A. C., Allen, J. F., Lane, N., and Martin, W. F.: Early bioenergetic evolution, Phil. Trans. R. Soc. B., 368, 1-30, 2013.

Southward, A. J.: Animal communities fueled by chemosynthesis: Life at hydrothermal vents, cold seeps and in reducing sediments, J. Zool., Lond., 217, 705-709, 1989.

Stoecker, K., Bendinger, B., Schöning, B., Nielsen, P. H., Nielsen, J. L., Baranyi, C., Toenshoff, E. R., Daims, H., and Wagner, M.: Cohn's Crenothrix is a filamentous methane oxidizer with an unusual methane monooxygenase, PNAS, 103, 2363-2367, 2006.

Thiel, V., Peckmann, J., Seifert, R., Wehrung, P., Reitner, J., and Michaells, W.: Highly isotopically depleted isoprenoids: molecular markers for ancient methane venting, Geochim. Cosmochim. Ac., 63, 3959-3966, 1999.

Timmers, P. H. A., Suarez-Zuluaga, D. A., Van Rossem, M., Diender, M., Stams, A. J. M., and Plugge, C. M.: Anaerobic oxidation of methane associated with sulfate reduction in a natural freshwater gas source, ISME J., 10, 1400-1412, 2016.

Timmers, P. H., Welte, C. U., Koehorst, J. J., Plugge, C. M., Jetten, M. S., and Stams, A. J.: Reverse methanogenesis and respiration in methanotrophic archaea. Archaea, 22 pp., 2017. 
Tunnicliffe, V., Juniper, S. K., and Sibuet, M.: Reducing environments of the deepsea floor, in: Ecosystems of the deep-sea oceans. Ecosystems of the world, Tyler, P. A. (Ed.), Elsevier, Amsterdam, 81-110, 2003.

Ueno, Y., Yamada, K., Yoshida, N., Maruyama, S., and Isozaki, Y.: Evidence from fluid inclusions for microbial methanogenesis in the early Archaean era, Nature, 440, 516-519, 2006.

Van Dover, C. (Ed.): The ecology of deep-sea hydrothermal vents, Princeton University Press, United Kingdom, 2000.

Valentine, D. L., and Reeburgh, W. S.: New perspectives on anaerobic methane oxidation, Environ. Microbiol., 2(5), 477-484, 2000.

Vanwonterghem, I., Evans, P. N., Parks, D. H., Jensen, P. D., Woodcroft, B. J., Hugenholtz, P., and Tyson, G. W.: Methylotrophic methanogenesis discovered in the archaeal phylum Verstraetearchaeota, Nat. Microbiol., 1(16170), 1-19, 2016.

Venn, A. A., Loram. J. E., and Douglas, A. E.: Photosynthetic symbioses in animals, J. Exp. Bot., 59(5), 1069-1080, 2008.

Ver Eecke, H. C., Butterfield, D. A., Huber, J. A., Lillye, M. D., Olson, E. J., Roe, K. K., Evans, L. J., Merkel, A. Y., Cantin, H. V., and Holden, J. F.: Hydrogenlimited growth of hyperthermophilic methanogens at deep-sea hydrothermal vents, PNAS, 109(34), 13674-13679, 2012.

Vigliotta, G., Nutricati, E., Carata, E., Tredici, S. M., De Stefano, M., Pontieri, P., Massardo, D. R., Prati, M. V., De Bellis, L., and Alifano, P.: Clonothrix fusca Roze 1896, a filamentous, sheathed, methanotrophic g-Proteobacterium, Appl. Environ. Microbiol., 73, 3556-3565, 2007.

Von Damm, K. L.: Controls on the chemistry and temporal variability of seafloor hydrothermal fluids, in: Seafloor Hydrothermal Systems: Physical, Chemical, Biological and Geological Interactions, Humphris, S. E., Zierenberg, R. A., Mullineaux, L. S, and Thomson, R. E. (Eds.), American Geophysical Union, Washington D. C, 222-247, 1995. 
Wasmund, K., Mußmann, M., and Loy, A.: They life sulfuric: microbial ecology of sulfur cycling in marine sediments, Env. Microbiol. Rep., 9(4), 323-344, 2017.

Weiss, M. C., Sousa, F. L., Mrnjavac, N., Neukirchen, S., Roettger, M., Nelson-Sathi, S., and Martin, W. F.: The physiology and habitat of the last universal common ancestor, Nature Microbiology, 1(9), 2016.

Whitman, W. B., Bowen, T. L., and Boone, D. R.: The methanotrophic bacteria, in: Prokaryotes, Dworkin, M., Falkow, S., Rosenberg, E., Schleifer, K., and Stackebrandt, E. (Eds.), Springer, New York, 165-207, 2006.

Whittenbury, R., and Dalton, H.: The methylotrophic bacteria, in: Prokaryotes, Starr, M. P., Stolp, H., Trüper, H. G., Balows, A., and Schlegel, H. G. (Eds.), Springer, Germany, 894-902, 1981.

Wrede, C., Krukenberg, V., Dreier, A., Reitner, J., Heller, C., and Hoppert, M.: Detection of Metabolic Key Enzymes of Methane Turnover Processes in Cold Seep Microbial Biofilms, Geomicrobiol. J., 30(3), 214-227, 2013.

Xing, R. Y., and Whitman, W. B.: Sulfometuron methyl -sensitive and -resistant acetolactate synthases of the archaebacteria Methanococcus spp., J. Bacteriol., 169, 4486-4492, 1987.

Zeikus, J. G.: The biology of methanogenic bacteria, Bacteriol. Rev., 41(2), 514-541, 1977. 


\title{
2 Cold-water corals affected by hydrocarbon-rich seepage - living on the edge
}

Blanca Rincón-Tomás ${ }^{1}$, Jan-Peter Duda ${ }^{2,3}$, Luis Somoza ${ }^{4}$, Javier González ${ }^{4}$, Dominik Schneider $^{1}$, Teresa Medialdea ${ }^{4}$, Pedro Madureira ${ }^{5}$, Michael Hoppert ${ }^{1}$, and Joachim Reitner $^{2,3}$

${ }^{1}$ Georg-August-University Göttingen, Institute of Microbiology and Genetics, Grisebachstraße 8, 37077 Göttingen, Germany

${ }^{2}$ Georg-August-University Göttingen, Göttingen Centre of Geosciences, Goldschmidtstraße 3, 37077 Göttingen, Germany

${ }^{3}$ Göttingen Academy of Sciences and Humanities, Theaterstraße 7, 37073 Göttingen, Germany

${ }^{4}$ Marine Geology Dept., Geological Survey of Spain, IGME, Ríos Rosas 23, 28003 Madrid, Spain

${ }^{5}$ Estrutura de Missão para a Extensão da Plataforma Continental. Rua Costa Pinto 165, 2770-047 Paço de Arcos, Portugal

Correspondence to: Blanca Rincón-Tomás (‥rincontomas@gmail.com)

\begin{abstract}
Azooxanthellate cold-water corals (CWCs) are globally widespread and have commonly been found in areas of active fluid seepage. The relationship between the CWCs and these fluids, however, is not well understood. This study aims at unravelling the relationship between $\mathrm{CWC}$ development and hydrocarbon-rich seepage in the Pompeia Province (Gulf of Cádiz, Atlantic Ocean). This region comprises mud volcanoes, coral ridges and fields of coral mounds, which are all affected by the tectonically driven seepage of hydrocarbon-rich fluids. Rate and type of seepage (i.e. focused, scattered, diffused, eruptive), however, is tightly controlled by a complex system of faults and diapirs. Early diagenetic carbonates from the currently active $\mathrm{Al}$ Gacel MV exhibit $\delta^{13} \mathrm{C}$-signatures down to $-28.77 \%$ VPDB, indicating biologically derived methane as the main carbon source. The same samples
\end{abstract}


contained ${ }^{13} \mathrm{C}$-depleted lipid biomarkers diagnostic for archaea such as crocetane $\left(\delta^{13} \mathrm{C}\right.$ down to $-101.2 \%$ VPDB) and PMI ( $\delta^{13} \mathrm{C}$ down to $-102.9 \%$ VPDB), evidencing microbially mediated anaerobic oxidation of methane (AOM). This is further supported by next generation DNA sequencing data, demonstrating the presence of AOM related microorganisms (ANME archaea, sulfate-reducing bacteria) in the carbonate. Embedded corals in some of the carbonates and CWC fragments exhibit less negative $\delta^{13} \mathrm{C}$ values ( -8.08 to $-1.39 \%$ VPDB), pointing against the use of methane as carbon source. Likewise, the absence of DNA from methane- and sulfideoxidizing microbes in a sampled coral does not support a chemosynthetic lifestyle of these organisms. In the light of these findings, it appears that the CWCs benefit rather indirectly from hydrocarbon-rich seepage by using methane-derived authigenic carbonates as substratum for colonization. At the same time, chemosynthetic organisms at active sites prevent coral dissolution and necrosis by feeding on the seeped fluids (i. e. methane, sulfate, hydrogen sulfide), allowing cold-water corals to colonize carbonates currently affected by hydrocarbon-rich seepage.

\subsection{Introduction}

Cold-water corals (CWCs) are a widespread, non-phylogenetic group of cnidarians which include hard skeleton scleractinian corals, soft-tissue octocorals, gold corals, black corals and hydrocorals (Roberts et al., 2006, 2009; Cordes et al., 2016). They typically thrive at low temperatures $\left(4-12^{\circ} \mathrm{C}\right)$ and occur in water depths of ca. $50-$ $4000 \mathrm{~m}$. CWCs are azooxanthellate and solely rely on their nutrition as energy and carbon sources (Roberts et al., 2009). Some scleractinian corals (e.g. Lophelia pertusa, Madrepora oculata, Dendrophyllia cornigera, Dendrophyllia alternata, Eguchipsammia cornucopia) are able to form colonies or even large carbonate mounds (Rogers et al., 1999; Wienberg et al., 2009; Watling et al., 2011; Somoza et al., 2014). Large vertical mounds and elongated ridges formed by episodic growth of scleractinian corals (mainly Lophelia pertusa) are for instance widely distributed along the continental margins of the Atlantic Ocean (Roberts et al., 2009). These systems 
are of great ecological value since they offer sites for resting-, breeding-, and feeding for various invertebrates and fishes (Cordes et al., 2016 and references therein).

Several ecological forces are discussed to control the initial settling, growth, and decline of CWCs. These include, among others, an availability of suitable substrates for coral larvae settlement, low sedimentation rates, oceanographic boundary conditions (e.g. salinity, temperature and density of the ocean water) and a sufficient supply of nutrients through topographically controlled currents systems (e.g. Freiwald et al., 1999, 2002; Mortensen et al., 2001; Roberts et al., 2003; Thiem et al., 2006; Dorschel et al., 2007; Dullo et al., 2008; Frank et al., 2011; Van Rooij et al., 2011; Hebbeln et al., 2016). Alternatively, CWC ecosystems may be directly fueled by fluid seepage, providing a source of e.g. sulfur compounds, nitrogen compounds, $\mathrm{P}, \mathrm{CO}_{2}$ and/or hydrocarbons (Hovland, 1990; Hovland and Thomsen, 1997; Hovland et al., 1998). This relationship is supported by the common co-occurrence of CWC-mounds and hydrocarbon-rich seeps around the world as e.g. at the Hikurangi Margin in New Zealand (Liebetrau et al., 2010), the Brazil margin (e.g. Gomes-Sumida et al., 2004), the Darwin Mounds in the northern Rockall Trough (Huvenne et al., 2009), the Kristin field on the Norwegian shelf (Hovland et al., 2012), the western Alborán Sea (Margreth et al., 2011), and the Gulf of Cádiz (e.g. Díaz-del-Río et al., 2003; Foubert et al., 2008). However, CWCs may also benefit rather indirectly from seepage. For instance, methane-derived authigenic carbonates (MDACs) formed through the microbially mediated anaerobic oxidation of methane (AOM; Suess \& Whiticar, 1989; Hinrichs et al., 1999; Thiel et al., 1999; Boetius et al., 2000; Hinrichs \& Boetius, 2002; Valentine, 2002; Boetius \& Suess, 2004) potentially provide hard substrata for larval settlement (e.g. Díaz-del-Rio et al., 2003; Van Rooij et al., 2011; Magalhães et al. 2012; Le Bris et al., 2016; Rueda et al., 2016). On the other hand, larger hydrocarbonrich seepage related structures such as mud volcanoes and carbonate mud mounds act as morphological barriers favoring turbulent water currents that deliver nutrients to the corals (Roberts et al., 2009; Wienberg et al., 2009; Margreth et al., 2011; Vandorpe et al., 2016).

In the Gulf of Cádiz, most CWC occurrences are "coral graveyards" (i.e., with only 
few living corals) that are situated along the Iberian and Moroccan margins. These CWC systems are typically associated with diapiric ridges, steep fault-controlled escarpments, and mud volcanoes (MVs) such as the Faro MV, Hesperides MV, Mekness MV, and MVs in the Pen Duick Mud Volcano Province (Foubert et al., 2008; Wienberg et al., 2009). MVs (and other conspicuous morphological structures in this region such as pockmarks) are formed through tectonically induced fluid flow (Pinheiro et al., 2003; Somoza et al., 2003; Medialdea et al., 2009; León et al., 2012). This is because of the high regional tectonic activity and high fluid contents of sediments in this area (mainly $\mathrm{CH}_{4}$ and, to a lesser extent, $\mathrm{H}_{2} \mathrm{~S}, \mathrm{CO}_{2}$, and $\mathrm{N}_{2}$ : Pinheiro et al., 2003; Hensen et al., 2007; Scholz et al., 2009; Smith et al., 2010; González et al., 2012). However, the exact influence of fluid flow on CWC growth in this region remains elusive.

This study aims at elucidating the linkage between the present-day formation of MDACs and CWCs development along the Pompeia Province (Fig. 1), which englobes mud volcanoes as the Al Gacel MV (León et al., 2012), diapiric coral ridges and mounds. We address this question by the combined analysis of high-resolution ROV underwater images, geophysical data (e.g. seabed topography, deep highresolution multichannel seismic reflection data), and sample materials (petrographic features, $\delta^{13} \mathrm{C}$ - and $\delta^{18} \mathrm{O}$-signatures of carbonates, lipid biomarkers and environmental 16s rDNA sequences of the prokaryotic microbial community). Based on our findings, we propose an integrated model to explain the tempo-spatial and genetic relations between CWCs, chemosynthetic fauna and hydrocarbon-rich seepage in the study area.

\subsection{Materials and Methods}

This study is based on collected data from the Pompeia Province, during the Subvent2 cruise in 2014 aboard the R/V Sarmiento de Gamboa. The analyzed samples were recovered from the Al Gacel MV (D10-R3, D10-R7, D11-R8) and the Northern Pompeia Coral Ridge (D03-B1) (Fig. 1). 


\subsubsection{Geophysical survey}

Seabed topography of the studied sites was mapped by using an Atlas Hydrosweep DS (15 kHz and 320 beams) multibeam echosounder (MBES). Simultaneously, ultra-high resolution sub-bottom profiles were acquired with an Atlas Parasound P-35 parametric chirp profiler $(0.5-6 \mathrm{kHz})$. Deep high-resolution multichannel seismic reflection data was obtained using an array of 7 SERCEL gi-guns (system composed of $250+150+$ $110+45$ cubic inches) with a total of 860 cubic inches. The obtained data were recorded with an active streamer (SIG®16.3x40.175; $150 \mathrm{~m}$ length with 3 sections of 40 hydrophones each). The shot interval was 6 seconds and the recording length 5 seconds two-way travel time (TWT). Data processing (filtering and stacking) was performed on board with Hot Shots software.

\subsubsection{Video survey and analysis}

A remotely operated vehicle (ROV-6000 Luso) was used for photographic documentation (high definition digital camera, 1024x1024 pixel) and sampling. The ROV was further equipped with a STD/CTD-SD204 sensor (in-situ measurements of salinity, temperature, oxygen, conductivity, sound velocity and depth), HydroC ${ }^{\mathrm{TM}}$ sensors (in-situ measurements of $\mathrm{CO}_{2}$ and $\left.\mathrm{CH}_{4}\right)$ and Niskin bottles $\left(\mathrm{CH}_{4}\right.$ concentrations).

\subsubsection{Petrographic analysis}

General petrographic analysis was performed on thin sections (ca. $60 \mu \mathrm{m}$ thickness) with a Zeiss SteREO Discovery.V8 stereomicroscope (transmitted- and reflected light) linked to an AxioCam MRc 5-megapixel camera. Additional detailed petrographic analysis of textural and mineralogical features was conducted on polished thin sections (ca. $30 \mu \mathrm{m}$ thickness) using a DM2700P Leica Microscope coupled to a DFC550 digital camera. Carbonate textures have been classified following Dunham (1962) and Embry III \& Klovan (1971). 


\subsubsection{Stable isotopes $\left(\delta^{13} \mathrm{C}, \delta^{18} \mathrm{O}\right)$ of carbonate}

Stable carbon and oxygen isotope measurements were conducted on ca. $0.7 \mathrm{mg}$ carbonate powder obtained with a high precision drill $(\varnothing 0.8 \mathrm{~mm})$. The analyses were performed with a Thermo Scientific Kiel IV carbonate device coupled to a Finnigan Delta Plus gas isotope mass spectrometer. Reproducibility was checked through the replicate analysis of a standard (NBS19) and was generally better than $0.1 \%$. Stable carbon and oxygen isotope values are expressed in the standard $\delta$ notation as per mill (\%) deviations relative to Vienna Pee Dee Belemnite (VPDB).

\subsubsection{Lipid biomarker analysis}

\section{Sample preparation}

All materials used were pre-combusted $\left(500{ }^{\circ} \mathrm{C}\right.$ for $\left.>3 \mathrm{~h}\right)$ and/or extensively rinsed with acetone prior to sample contact. A laboratory blank (pre-combusted sea sand) was prepared and analyzed in parallel to monitor laboratory contaminations.

The preparation and extraction of lipid biomarkers was conducted in orientation to descriptions in Birgel et al. (2006). Briefly, the samples were first carefully crushed with a hammer and internal parts were powdered with a pebble mill (Retsch MM 301, Haan, Germany). Hydrochloric acid $(\mathrm{HCl} ; 10 \%)$ was slowly poured on the powdered samples which were covered with dichloromethane (DCM)-cleaned water. After $24 \mathrm{~h}$ of reaction, the residues $(\mathrm{pH} 3-5)$ were repeatedly washed with water and then lyophilized.

$3 \mathrm{~g}$ of each residue was saponified with potassium hydroxide $(\mathrm{KOH} ; 6 \%)$ in methanol $(\mathrm{MeOH})$. The residues were then extracted with methanol $(40 \mathrm{~mL}, 2 \mathrm{x})$ and, upon treatment with $\mathrm{HCl}(10 \%)$ to $\mathrm{pH}$ 1, in $\mathrm{DCM}(40 \mathrm{~mL}, 2 \mathrm{x})$ by using ultra-sonification. The combined supernatants were partitioned in DCM vs. water (3x). The total organic extracts (TOEs) were dried with sodium sulfate $\left(\mathrm{NaSO}_{4}\right)$ and evaporated with a gentle stream of $\mathrm{N}_{2}$ to reduce loss of low-boiling compounds (cf. Ahmed and George, 2004). $50 \%$ of each TOE was separated over a silica gel column ( $0.7 \mathrm{~g}$ Merck silica gel 60 conditioned with $n$-hexane; $1.5 \mathrm{~cm}$ i.d., $8 \mathrm{~cm}$ length) into (a) hydrocarbon $(6 \mathrm{~mL} n$ hexane), (b) alcohol (7 mL DCM/acetone, 9:1, v:v) and (c) carboxylic acid fractions 
(DCM/MeOH, 3:1, v:v). Only the hydrocarbons were subjected to gas chromatography-mass spectrometry (GC-MS).

Gas chromatography-mass spectrometry (GC-MS)

Lipid biomarker analyses of the hydrocarbon fraction were performed with a Thermo Scientific Trace 1310 GC coupled to a Thermo Scientific Quantum XLS Ultra MS. The GC was equipped with a capillary column (Phenomenex Zebron ZB-5MS, $30 \mathrm{~m}$ length, $250 \mu \mathrm{m}$ inner diameter, $0.25 \mu \mathrm{m}$ film thickness). Fractions were injected into a splitless injector and transferred to the column at $300{ }^{\circ} \mathrm{C}$. The carrier gas was $\mathrm{He}$ at a flow rate of $1.5 \mathrm{~mL} \mathrm{~min}^{-1}$. The $\mathrm{GC}$ oven temperature was ramped from $80^{\circ} \mathrm{C}(1 \mathrm{~min})$ to $310{ }^{\circ} \mathrm{C}$ at $5{ }^{\circ} \mathrm{C} \min ^{-1}$ (held for $20 \mathrm{~min}$ ). Electron ionization mass spectra were recorded in full scan mode at an electron energy of $70 \mathrm{eV}$ with a mass range of $\mathrm{m} / \mathrm{z} 50$ -600 and scan time of $0.42 \mathrm{~s}$. Identification of individual compounds was based on comparison of mass spectra and GC retention times with published data and reference compounds.

Gas chromatography-combustion-isotope ratio mass spectrometer (GC-C-IRMS)

Compound specific $\delta^{13} \mathrm{C}$ analyses were conducted with a Trace GC coupled to a Delta Plus IRMS via a combustion-interface (all Thermo Scientific). The combustion reactor contained $\mathrm{CuO}, \mathrm{Ni}$ and $\mathrm{Pt}$ and was operated at $940^{\circ} \mathrm{C}$. The $\mathrm{GC}$ was equipped with two serially linked capillary columns (Agilent DB-5 and DB-1; each $30 \mathrm{~m}$ length, $250 \mu \mathrm{m}$ inner diameter, $0.25 \mu \mathrm{m}$ film thickness). Fractions were injected into a splitless injector and transferred to the $\mathrm{GC}$ column at $290^{\circ} \mathrm{C}$. The carrier gas was $\mathrm{He}$ at a flow rate of $20 \mathrm{ml} \mathrm{min}^{-1}$. The temperature program was identical to the one used for GC-MS (see above). $\mathrm{CO}_{2}$ with known $\delta^{13} \mathrm{C}$ value was used for internal calibration. Instrument precision was checked using a mixture of $n$-alkanes with known isotopic composition. Carbon isotope ratios are expressed as $\delta^{13} \mathrm{C}(\%)$ relative to VPDB. 


\subsubsection{Amplicon sequencing of $16 \mathrm{~S}$ rRNA genes}

DNA extraction and $16 S$ rRNA gene amplification

About $1-4 \mathrm{~g}$ of solid samples were first mashed with mortar and liquid nitrogen to fine powder. Three biological replicates were used per sample. Total DNA was isolated with a Power Soil DNA Extraction Kit (MO BIO Laboratories, Carlsbad, CA). All steps were performed according to the manufacturer's instructions.

Bacterial amplicons of the V3 - V4 region were generated with the primer set MiSeq_Bacteria_V3_forward primer (5'TCGTCGGCAGCGTCAGATGTGTATAAGAGACAGCCTACGGGNGGCWGCA G-3') and MiSeq_Bacteria_V4_reverse primer (5'GTCTCGTGGGCTCGGAGATGTGTATAAGAGACAGGACTACHVGGGTATC TAATCC-3'). Likewise, archaeal amplicons of the V3 - V4 region were generated with the primer set MiSeq_Archaea_V3_forward primer (5'TCGTCGGCAGCGTCAGATGTGTATAAGAGACAG-

GGTGBCAGCCGCCGCGGTAA-3') and MiSeq_Archaea_V4_reverse primer (5'GTCTCGTGGGCTCGGAGATGTGTATAAGAGACAG-

CCCGCCAATTYCTTTAAG-3'). $50 \mu \mathrm{l}$ of the PCR reaction mixture for bacterial DNA amplification, contained $1 \mathrm{U}$ Phusion high fidelity DNA polymerase (Biozym Scientific, Oldendorf, Germany), 5\% DMSO, $0.2 \mathrm{mM}$ of each primer, $200 \mu \mathrm{M}$ dNTP, $0.15 \mu \mathrm{l}$ of $25 \mathrm{mM} \mathrm{MgCl}_{2}$, and $25 \mathrm{ng}$ of isolated DNA. The PCR protocol for bacterial DNA amplification included (i) initial denaturation for $1 \mathrm{~min}$ at $98^{\circ} \mathrm{C}$, (ii) 25 cycles of $45 \mathrm{~s}$ at $98^{\circ} \mathrm{C}, 45 \mathrm{~s}$ at $60{ }^{\circ} \mathrm{C}$, and $30 \mathrm{~s}$ at $72^{\circ} \mathrm{C}$, and (iii) a final extension at $72{ }^{\circ} \mathrm{C}$ for 5 min. The PCR reaction mixture for archaeal DNA amplification was similarly prepared but contained instead $1 \mu \mathrm{l}$ of $25 \mathrm{mM} \mathrm{MgCl}_{2}$ and $50 \mathrm{ng}$ of isolated DNA. The PCR protocol for archaeal DNA amplification included (i) initial denaturation for $1 \mathrm{~min}$ at $98^{\circ} \mathrm{C}$, (ii) 10 cycles of $45 \mathrm{~s}$ at $98^{\circ} \mathrm{C}, 45 \mathrm{~s}$ at $63^{\circ} \mathrm{C}$, and $30 \mathrm{~s}$ at $72{ }^{\circ} \mathrm{C}$, (iii) 15 cycles of $45 \mathrm{~s}$ at $98{ }^{\circ} \mathrm{C}, 45 \mathrm{~s}$ at $53{ }^{\circ} \mathrm{C}$, and $30 \mathrm{~s}$ at $72{ }^{\circ} \mathrm{C}$, and (iv) a final extension at $72{ }^{\circ} \mathrm{C}$ for $5 \mathrm{~min}$.

PCR products were checked by agarose gel electrophoresis and purified using the GeneRead Size Selection Kit (QIAGEN GmbH, Hilden, Germany). 


\section{Data analysis and pipeline}

Illumina PE sequencing of the amplicons and further process of the sequence data were performed in the Göttingen Genomics Laboratory (Göttingen, Germany). After Illumina MiSeq processing, sequences were analyzed as described in Egelkamp et al. (2017) with minor modifications. In brief, paired-end sequences were merged using PEAR v0.9.10 (Zhang et al., 2014), sequences with an average quality score below 20 and containing unresolved bases were removed with QIIME 1.9.1 (Caporaso et al., 2010). Non-clipped reverse and forward primer sequences were removed by employing cutadapt 1.15 (Martin, 2011). USEARCH version 9.2.64 was used following the UNOISE pipeline (Edgar, 2010). In detail, reads shorter than $380 \mathrm{bp}$ were removed, dereplicated, and denoised with the UNOISE2 algorithm of USEARCH resulting in amplicon sequence variants (ASVs) (Callahan et al., 2017). Additionally, chimeric sequences were removed using UCHIME2 in reference mode against the SILVA SSU database release 132 (Yilmaz et al., 2014). Merged pairedend reads were mapped to chimera-free ASVs and an abundance table was created using USEARCH. Taxonomic classification of ASVs was performed with BLAST against the SILVA database 132. Extrinsic domain ASVs, chloroplasts, and unclassified ASVs were removed from the dataset. Sample comparisons were performed at same surveying effort, utilizing the lowest number of sequences by random subsampling (20,290 reads for bacteria, 13,900 reads for archaea).

The paired-end reads of the 16S rRNA gene sequencing were deposited in the National Center for Biotechnology Information (NCBI) in the Sequence Read Archive SRP156750. 


\subsection{Results}

\subsubsection{The Pompeia Province - geological settings}

The Pompeia Province is situated in the Gulf of Cádiz offshore Morocco, within the so-called Middle Moroccan Field (Ivanov et al., 2000) at water-depths between 860 and $1000 \mathrm{~m}$ (Fig. 1). It compromises the active Al Gacel MV (Fig. 1, C), another mud volcano which is extinct (further referred as extinct MV) and two east-west elongated ridges (Northern Pompeia Coral Ridge and Southern Pompeia Coral Ridge). Scattered coral-mounds surround the ridges with a smooth relief (Fig. 1, B). CWCs were observed on seismic profiles resting on all these morphological features. Detailed geological profiles and 3D images of these features are shown in Figs. 2 and 3.

The Al Gacel MV is a cone-shape structure, $107 \mathrm{~m}$ high and $944 \mathrm{~m}$ wide, with its summit at $762 \mathrm{~m}$ depth and surrounded by a $11 \mathrm{~m}$ deep rimmed depression (León et al., 2012) (Fig. 1, C). It is directly adjacent to the Northern Pompeia Coral Ridge (Fig. 2, A-B), which extends ca. $4 \mathrm{~km}$ in westward direction (Fig. 2, A-B) and it is terminated by the Pompeia Escarpment (Fig. 1, B; Fig. 2, C). High resolution seismic profiles of the Pompeia Escarpment show CWC build-ups (R1 to R4) with steep lateral scarps of ca. $40 \mathrm{~m}$ height (Fig. 2, C). This MV is of sub-circular shape and exhibits a crater at its top (Fig. 2, A-B). 


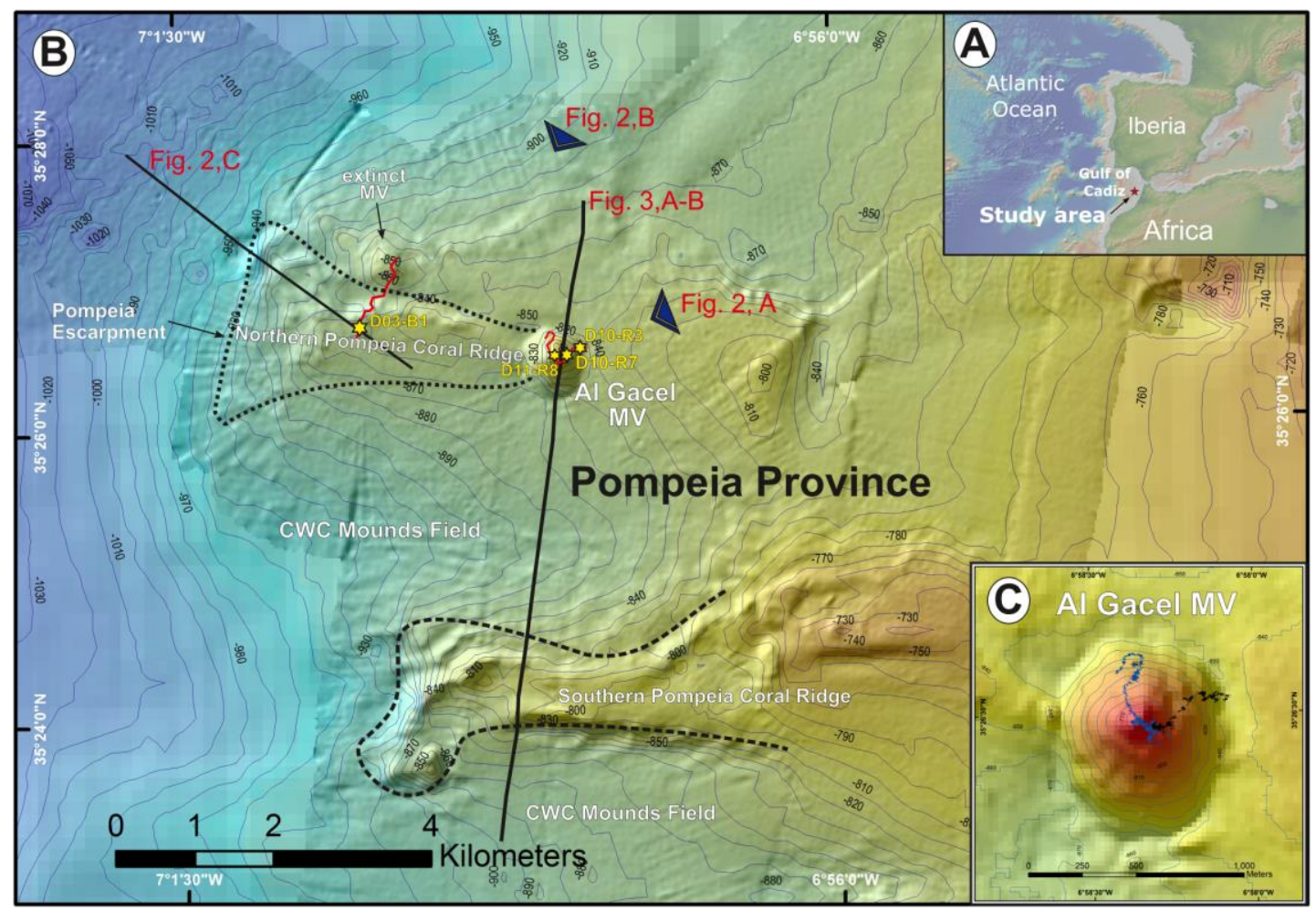

Figure 1: Bathymetric map of the study area. A: location of the Gulf of Cádiz between Spain, Portugal and Morocco. The study area is marked with a red star; B: the Pompeia Province including its different morphological features. Red lines indicate ROV-paths, yellow stars mark sampling sites; C: detailed map of the Al Gacel MV including pathways of Dive 10 and 11 (black and blue lines, respectively). Further details of the area are provided in Figs. 2 and 3. 

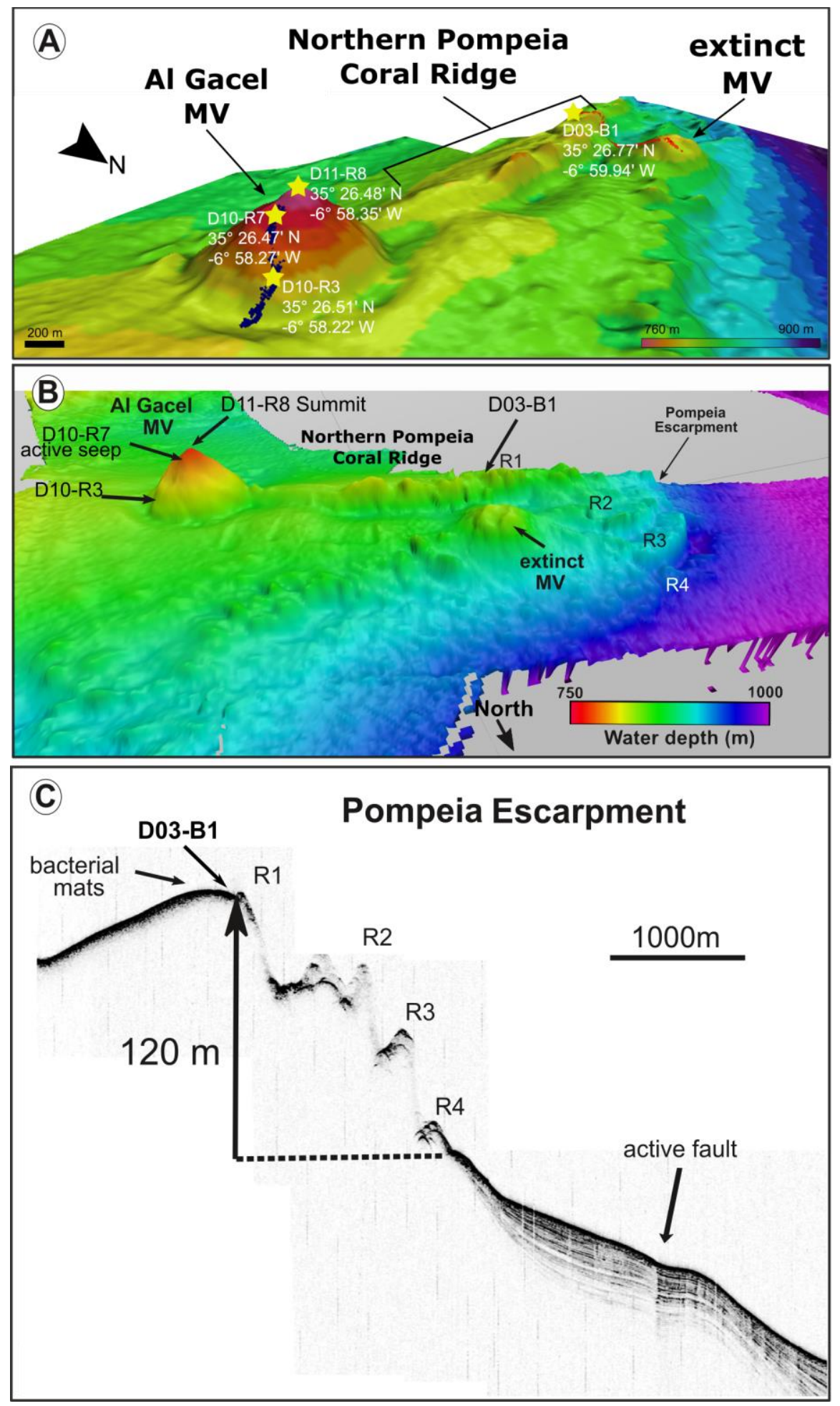

Figure 2: Bathymetric and seismic maps showing morphological features in the northern Pompeia Province. A-B: bathymetric maps showing the Al Gacel MV, the Northern Pompeia Coral Ridge and 
the extinct MV. Yellow stars mark sampling sites. C: seismic profile of the Pompeia Escarpment, westwards of the Northern Pompeia Ridge.

Ultra-high resolution sub-bottom seismic profile crossing the Pompeia Province from northwest (NW) to southeast (SE) (Fig. 3, A), shows (i) the Al Gacel MV surrounded by bottom-current deposits, (ii) an up to $130 \mathrm{~m}$ high CWC framework, growing on top the Southern Pompeia Coral Ridge, and (iii) semi-buried CWC mounds surrounding the ridge in areas of low relief. These CWC mounds locally form smooth, up to $25-$ $30 \mathrm{~m}$ high top-rounded reliefs that are exposed, but then taper downward below the seafloor (applying sound speeds of $1750 \mathrm{~m} / \mathrm{s}$ in recent sediments). Additionally, a multichannel seismic profile following the same track but with higher penetration below the seafloor (Fig. 3, B) shows high amplitude reflections inside the Al Gacel cone and enhanced reflections at the top of the diapirs (yellow dotted-line in Fig. 3, B), pointing to the occurrence of gas (hydrocarbon)-charged sediments. It furthermore exhibits breaks in seismic continuity and diapiric structures at different depths below the Southern Pompeia Coral Ridge and the Al Gacel MV, evidencing a fault system (Fig. 3, B). These tectonic structures may promote the development of overpressure areas (OP in Fig. 3, B) and consequent upward fluid flow to the surface. 


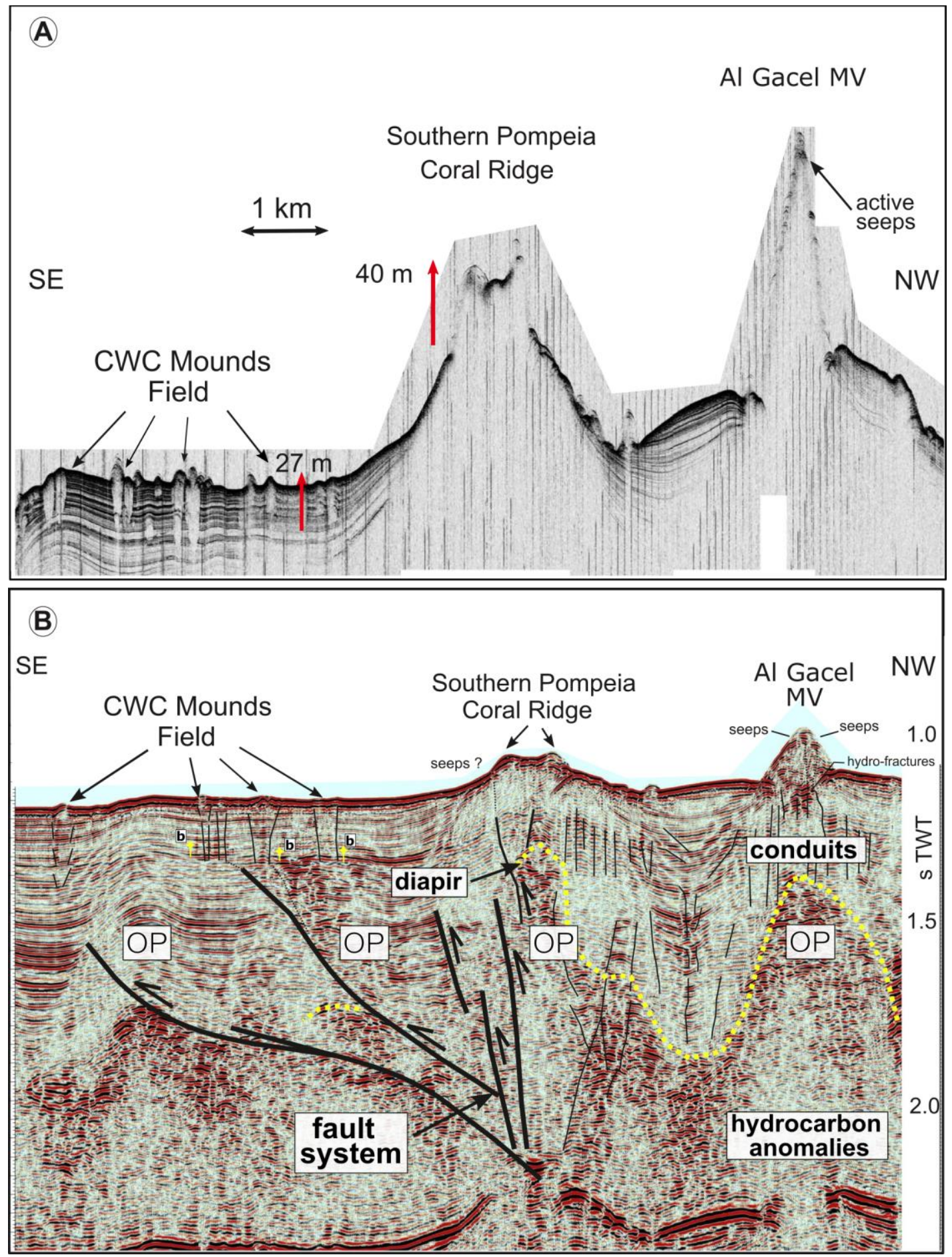

Figure 3: Seismic profiles showing geological features in the southern Pompeia Province. Note mud diapirism has been described in this area (Vandorpe et al., 2017). OP = overpressure zone. 


\subsubsection{ROV observation and measurements}

Submersible ROV surveys at the $\mathrm{Al} \mathrm{Gacel} \mathrm{MV} \mathrm{(Fig.} \mathrm{1,} \mathrm{C)} \mathrm{revealed} \mathrm{the} \mathrm{presence} \mathrm{of}$ dispersed pockmark depressions at the eastern (Dive 10,790 m) and northern flanks (Dive 11, $760-825 \mathrm{~m}$ depth). These sites are characterized by focused but low intensity seafloor bubbling (e.g. Fig. 4, B; Fig. 5, A). Analysis of water samples revealed $\mathrm{CH}_{4}$-concentration up to $171 \mathrm{nM}$ during Dive 10 and up to $192 \mathrm{nM}$ during Dive 11 (Sánchez-Guillamón et al., 2015). Pockmarks were essentially formed by grey-olive mud breccia sediments and characterized by deposits of authigenic carbonates appearing in the center and edges, together with typical methane-seep related organisms (e.g. sulfide-oxidizing bacterial mats, chemosynthetic bivalves, siboglinid tubeworms) (Fig. 4, B-C; Fig. 5). Communities of non-chemosynthetic organisms (e.g. sponges, corals) were also found at pockmarks (Fig. 4, B-C; Fig. 5, C), but were more abundant in places where no seepage was detected (Fig. 4, A). 

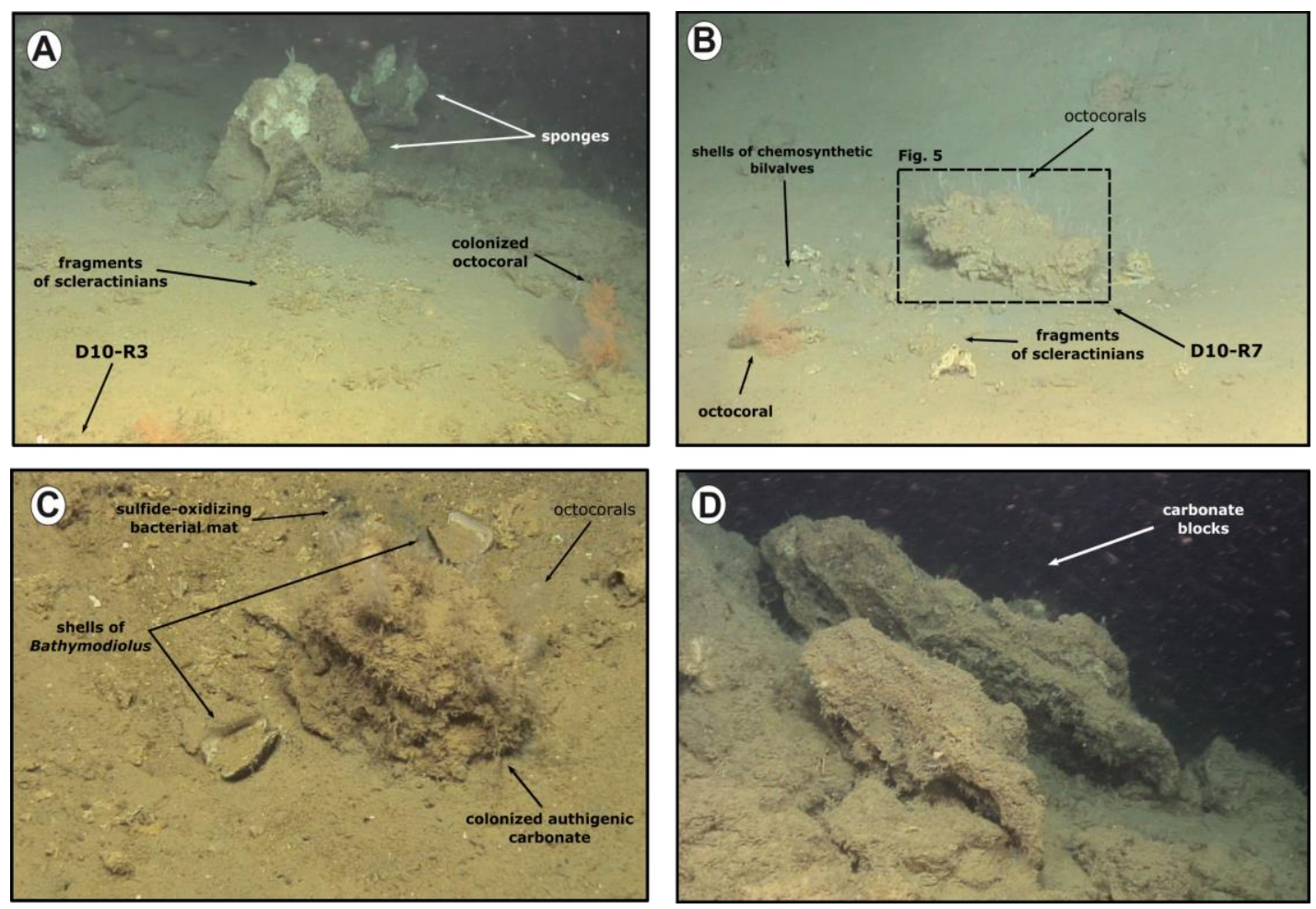

Figure 4: ROV still frames from the Al Gacel MV (Dives 10 and 11). A: eastern side of the volcano, displaying a field of sponges, corals and carbonates; B-C: pockmark sites on the east side of the volcano, displaying authigenic carbonate surrounded by shells of chemosynthetic bivalves, fragments of scleractinian and octocorals, as well as sulfide-oxidizing bacterial mats; D: metric-sized carbonate blocks located in a slope at the summit of the volcano. 

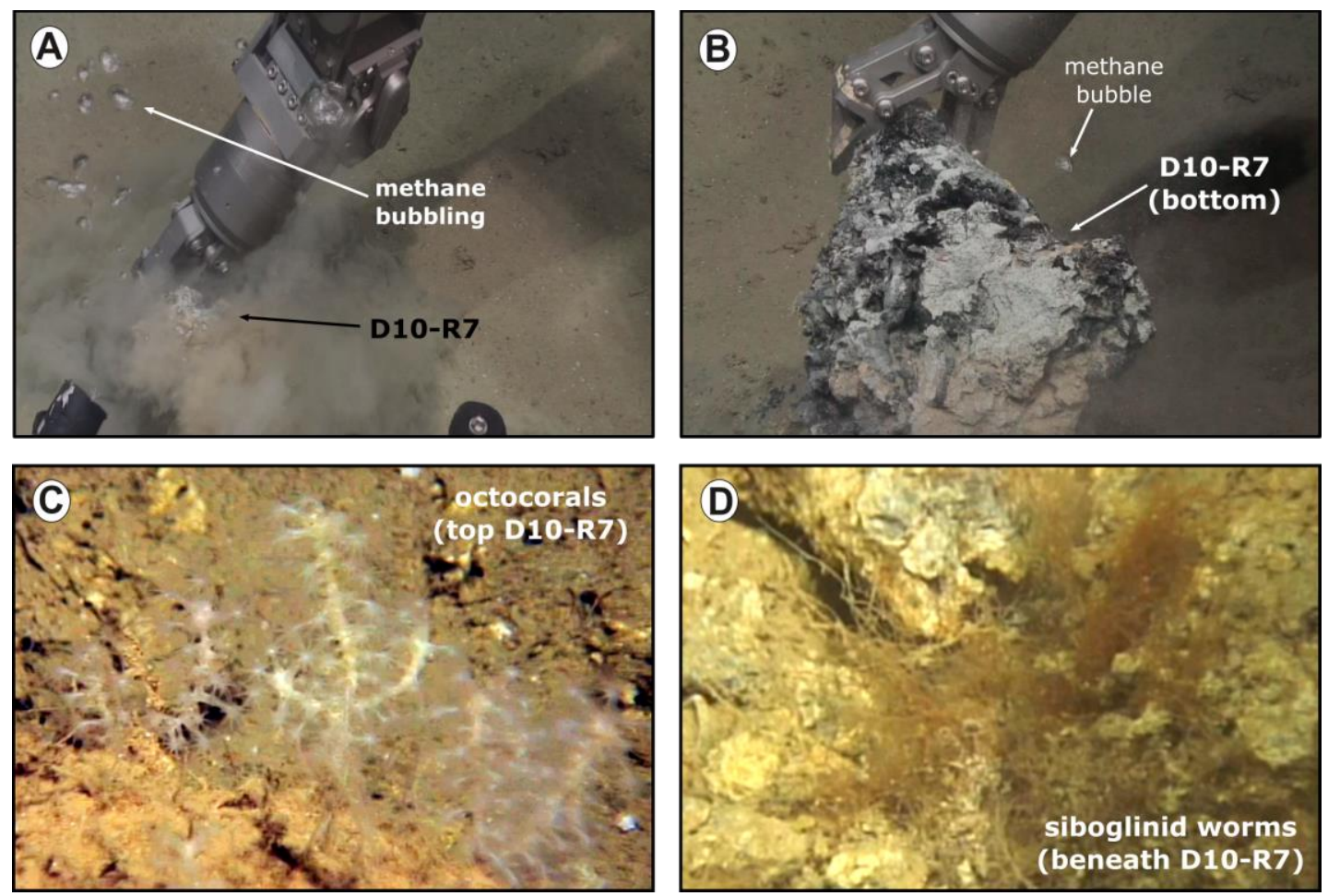

Figure 5: ROV still frames from the pockmark site shown in Fig. 4, B. A-B: release of bubbles while sampling; C: detailed photograph of the octocorals on top of the carbonate; D: detailed still frame from siboglinid worms beneath the carbonate.

Observations with the submersible ROV at the Northern Pompeia Coral Ridge and the extinct MV (Dive 03) revealed widespread and abundant occurrences of dead scleractinian-corals (mainly Madrepora oculata and Lophelia pertusa) currently colonized by few non-chemosynthetic organisms (e.g. Corallium tricolor, other octocorals, sea urchins) (Fig. 6, B-D). Locally, grey-black colored patches of sulfideoxidizing bacterial mats surrounded by dead chemosynthetic bivalves (Lucinoma asapheus and Thysira vulcolutre) were detected (Fig. 6, A). $\mathrm{CH}_{4}$-seepage appeared to be less than at the $\mathrm{Al} \mathrm{Gacel} \mathrm{MV,} \mathrm{with} \mathrm{concentrations} \mathrm{of} 80-83 \mathrm{nM}$.

Water parameters display homogenous values between the four sampling sites $\left(10^{\circ} \mathrm{C}\right.$ temperature, ca. $52-55 \%$ dissolved oxygen, ca. $31 \mathrm{Kg} / \mathrm{m}^{3}$ density) (Table 1). 
Table 1. In-situ water variables measured during sampling with ROV sensors.

\begin{tabular}{|l|l|l|l|l|}
\cline { 2 - 5 } \multicolumn{1}{l|}{} & D10-R3 & D10-R7 & D11-R8 & D03-B1 \\
\hline Temperature $\left({ }^{\circ} \mathrm{C}\right)$ & 10.07 & 10.5 & 10.02 & $10.04-10.05$ \\
Depth (m) & $850-890$ & 791 & 763 & 829 \\
Conductivity (mS/cm) & $39.13-39.62$ & $39.05-39.43$ & - & - \\
Salinity (ppt) & - & - & $35.56-35.86$ & $35.67-35.91$ \\
$\begin{array}{l}\text { Saturation of dissolved } \\
\text { oxygen }(\%)\end{array}$ & $53.64-54.69$ & $54.02-54.35$ & $51.95-53.92$ & $52.46-56.22$ \\
Dissolved oxygen (mg/l) & $4.81-4.90$ & $4.85-4.88$ & $4.66-4.84$ & $4.71-5.09$ \\
Density (kg/m $\left.{ }^{3}\right)$ & $31.03-31.42$ & $30.94-31.24$ & $30.92-31.08$ & $31.26-31.41$ \\
\hline
\end{tabular}
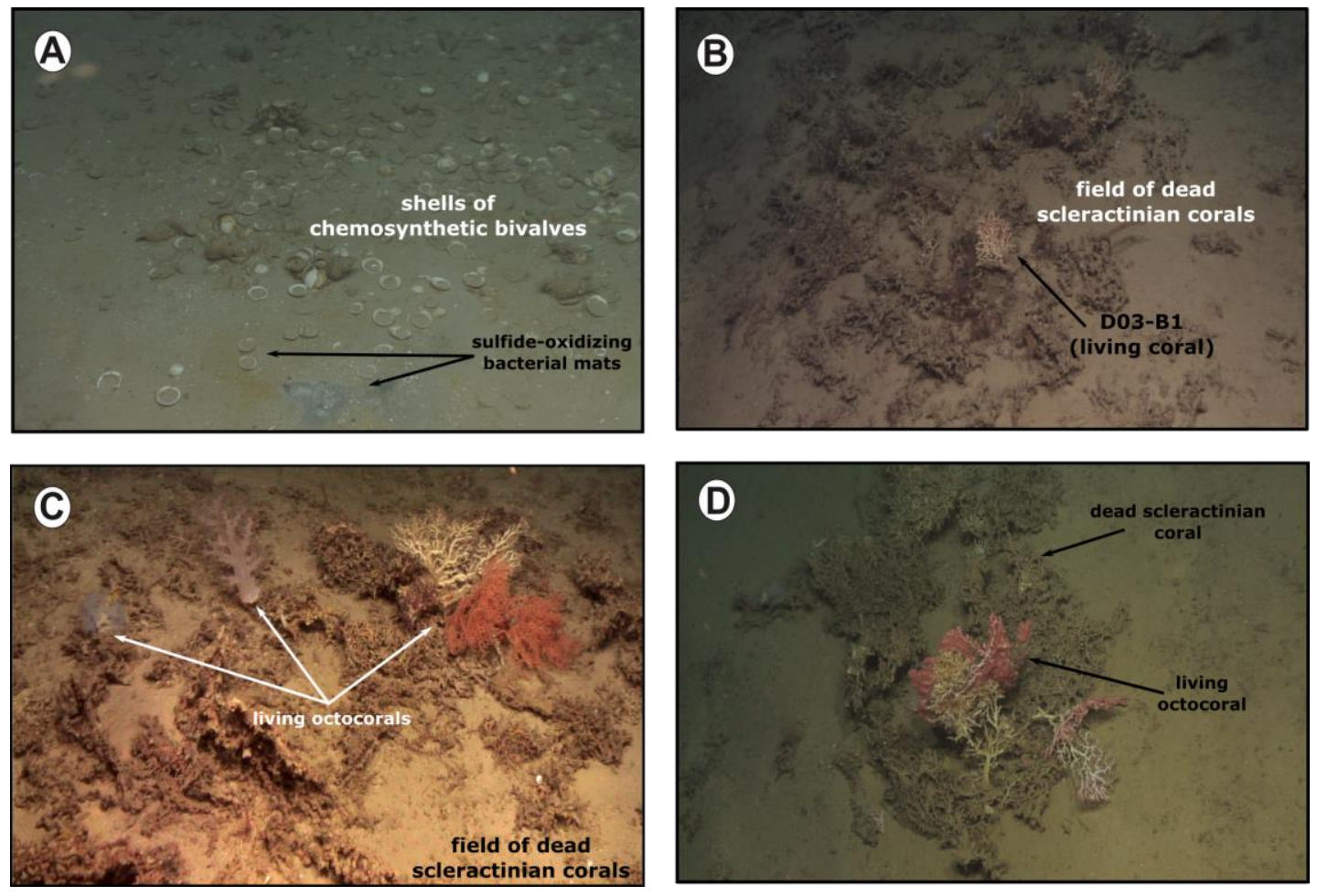

Figure 6: ROV still frames from the Northern Pompeia Coral Ridge and extinct MV (Dive 03). A: abundant shells of chemosynthetic bivalves with sulfide-oxidizing bacterial mats at the western site of the Northern Pompeia Coral Ridge; B-D: field of dead scleractinian-corals colonized by living corals; D: still frame from the extinct MV. 


\subsubsection{Petrography and stable isotopes signatures of carbonates $\left(\delta^{18} \mathrm{O}, \delta^{13} \mathrm{C}\right)$}

Sample D10-R3 derives from a field of carbonates at the base of the Al Gacel MV which is inhabited by sponges and corals (Fig. 4, A). The sample is a framestone composed of deep water scleractinian corals (Madrepora and rare Lophelia) (Fig. 7, A-B). The corals are typically cemented by microbial automicrite (sensu Reitner et al. 1995) followed by multiple generations of aragonite. A matrix of dark allomicrite (sensu Reitner et al. 1995) with oxidized framboidal pyrites and remains of planktonic foraminifera is restricted to few bioerosional cavities (ca. 5\%) in the skeletons of dead corals (Fig. 8, A-B). $\delta^{13} \mathrm{C}$ signatures of the matrix and cements range from -26.68 to $-18.38 \%$, while the embedded coral fragments exhibit $\delta^{13} \mathrm{C}$ values between -5.58 and $-2.09 \%$ (Fig. 7, B; Table 2). The $\delta^{18} \mathrm{O}$ values generally range from +2.35 to +3.92 \%o (Fig. 9; Table 2).

Sample D10-R7 was recovered from a pockmark on the eastern site of the Al Gacel MV that is virtually influenced by active seepage (Fig. 3, C). It consists of black carbonate and exhibits a strong hydrogen sulfide $\left(\mathrm{H}_{2} \mathrm{~S}\right)$ odor (Fig. 5, B; Fig. 7, C-D). The top of this sample was inhabited by living octocorals (Fig. 5, C), while chemosymbiotic siboglinid worms were present on the lower surface (Fig. 5, D). The sample is characterized by a grey peloidal wackestone texture consisting of allomicrite with abundant planktonic foraminifers and few deep water miliolids. The sample furthermore exhibits some fractured areas which are partly filled by granular and small fibrous cement, probably consisting of $\mathrm{Mg}$-calcite. Locally, light brownish crusts of microbial automicrite similar to ones in D10-R3 are present (see above). Framboidal pyrite is abundant and often arranged in aggregates (Fig. 8, C-D). The carbonate exhibits $\delta^{13} \mathrm{C}$ values ranging from -28.77 to $-21.13 \%$ and $\delta^{18} \mathrm{O}$ values from +2.37 to $+3.15 \%$ o (Fig. 9; Table 2). 
Table 2. Stable carbon and oxygen isotopes $\left(\delta^{13} \mathrm{C}, \delta^{18} \mathrm{O}\right)$ of samples from the Al Gacel MV and the Northern Pompeia Coral Ridge.

\begin{tabular}{|c|c|c|c|c|}
\hline Location & Sample & Identifier & $\begin{array}{c}\delta^{18} \mathrm{O} \\
(\%)\end{array}$ & $\begin{array}{l}\delta^{13} \mathbf{C} \\
(\%)\end{array}$ \\
\hline \multirow{26}{*}{ 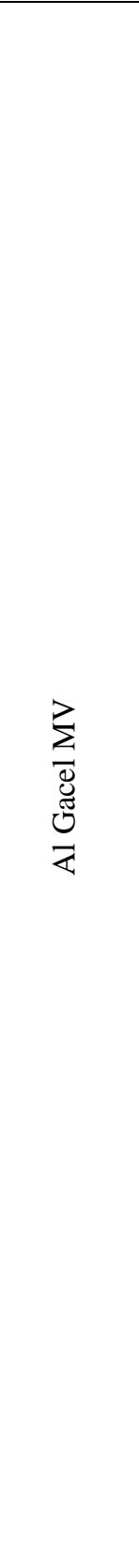 } & \multirow{15}{*}{ D10-R3 } & 1 & 2.35 & -5.58 \\
\hline & & 2 & 3.37 & -20.07 \\
\hline & & 3 & 3.60 & -26.68 \\
\hline & & 4 & 3.70 & -20.79 \\
\hline & & 5 & 3.45 & -22.43 \\
\hline & & 6 & 3.80 & -20.70 \\
\hline & & 7 & 3.28 & -2.23 \\
\hline & & 8 & 3.83 & -25.16 \\
\hline & & 9 & 3.63 & -25.29 \\
\hline & & 10 & 3.91 & -18.38 \\
\hline & & 11 & 3.60 & -24.18 \\
\hline & & 12 & 3.55 & -25.34 \\
\hline & & 13 & 3.56 & -25.15 \\
\hline & & 14 & 3.50 & -2.09 \\
\hline & & 15 & 3.92 & -21.89 \\
\hline & \multirow{6}{*}{ D10-R7 } & 21 & 2.90 & -26.36 \\
\hline & & 22 & 3.15 & -28.77 \\
\hline & & 23 & 2.94 & -22.91 \\
\hline & & 24 & 2.67 & -21.13 \\
\hline & & 25 & 2.37 & -24.70 \\
\hline & & 26 & 2.56 & -23.60 \\
\hline & \multirow{5}{*}{ D11-R8 } & 16 & 1.49 & -4.91 \\
\hline & & 17 & 2.13 & -2.99 \\
\hline & & 18 & 1.74 & -4.22 \\
\hline & & 19 & 5.60 & -14.82 \\
\hline & & 20 & 5.55 & -14.74 \\
\hline \multirow{4}{*}{ 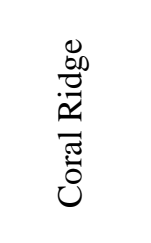 } & \multirow{4}{*}{ D03-B1 } & 1.1 & -0.38 & -7.93 \\
\hline & & 1.2 & -0.86 & -7.77 \\
\hline & & 1.3 & -0.51 & -7.35 \\
\hline & & 1.5 & 1.15 & -5.26 \\
\hline
\end{tabular}


Table 2: Continued

\begin{tabular}{|c|c|c|c|c|}
\hline Location & Sample & Identifier & $\begin{array}{c}\delta^{18} \mathrm{O} \\
(\%)\end{array}$ & $\begin{array}{l}\delta^{13} \mathbf{C} \\
(\%)\end{array}$ \\
\hline $\begin{array}{l}\frac{\Delta}{0} \\
\frac{0}{2} \\
\overrightarrow{0} \\
0 \\
0\end{array}$ & D03-B1 & $\begin{array}{l}1.4 \\
1.6 \\
1.7 \\
3.1 \\
3.2 \\
3.3 \\
3.4 \\
3.5 \\
3.6 \\
3.7\end{array}$ & $\begin{array}{l}-1.03 \\
0.69 \\
0.54 \\
1.59 \\
-0.31 \\
-0.89 \\
-0.94 \\
1.84 \\
2.26 \\
1.74\end{array}$ & $\begin{array}{l}-8.08 \\
-5.96 \\
-6.42 \\
-2.08 \\
-6.27 \\
-6.78 \\
-6.73 \\
-2.21 \\
-1.39 \\
-2.87\end{array}$ \\
\hline
\end{tabular}



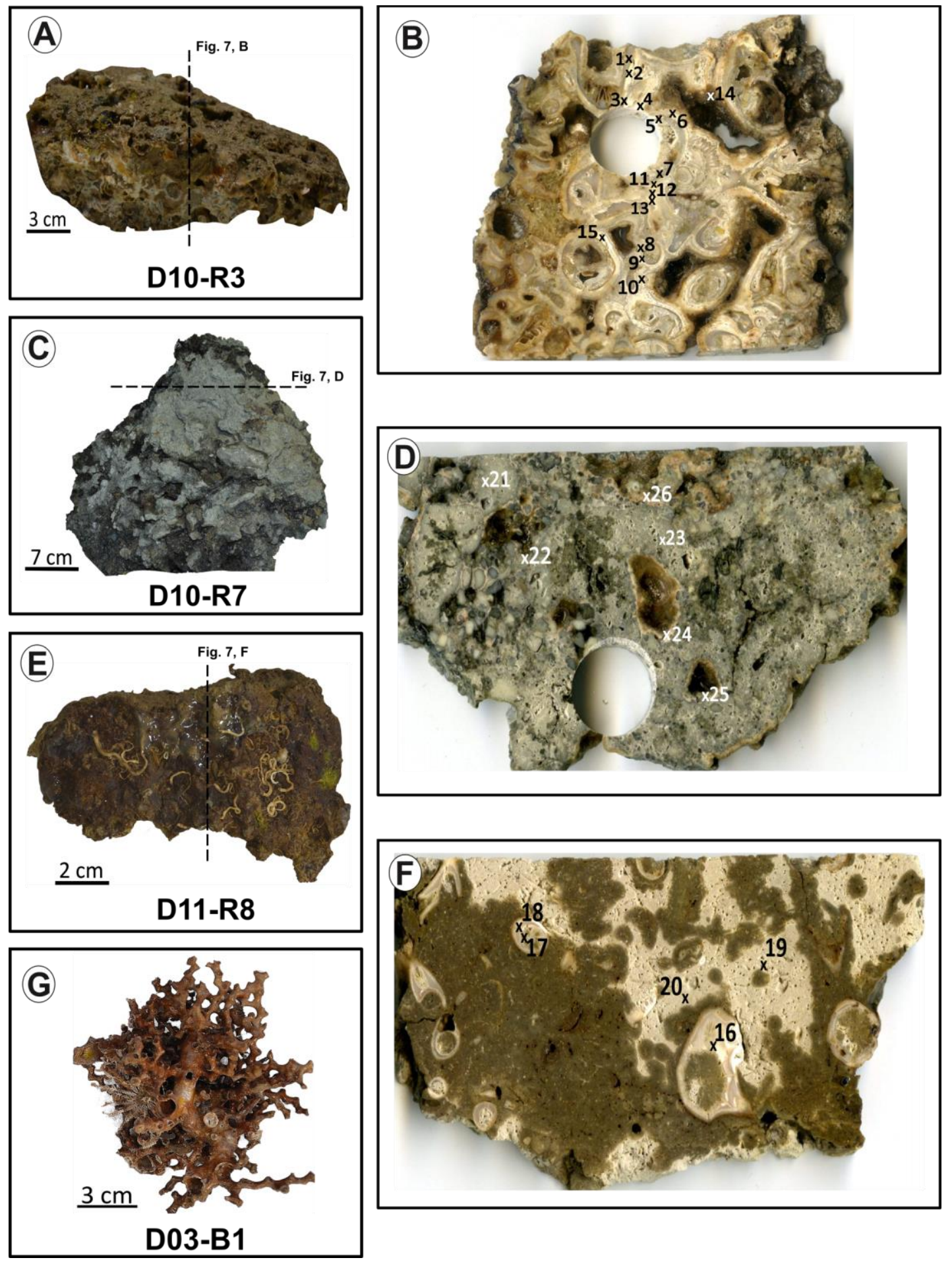

Figure 7: Photographs of analyzed samples including sampling sites for stable carbon and oxygen isotope $\left({ }^{13} \mathrm{C}, \delta^{18} \mathrm{O}\right)$ analysis (crosses). A-B: D10-R3 carbonate with embedded corals; C-D: D10-R7 carbonate with strong $\mathrm{H}_{2} \mathrm{~S}$ odor; $\mathbf{E}-\mathbf{F}$ : D11-R8 carbonate with embedded corals; G: D03-B1 scleractinian-coral fragment, Madrepora oculata. 

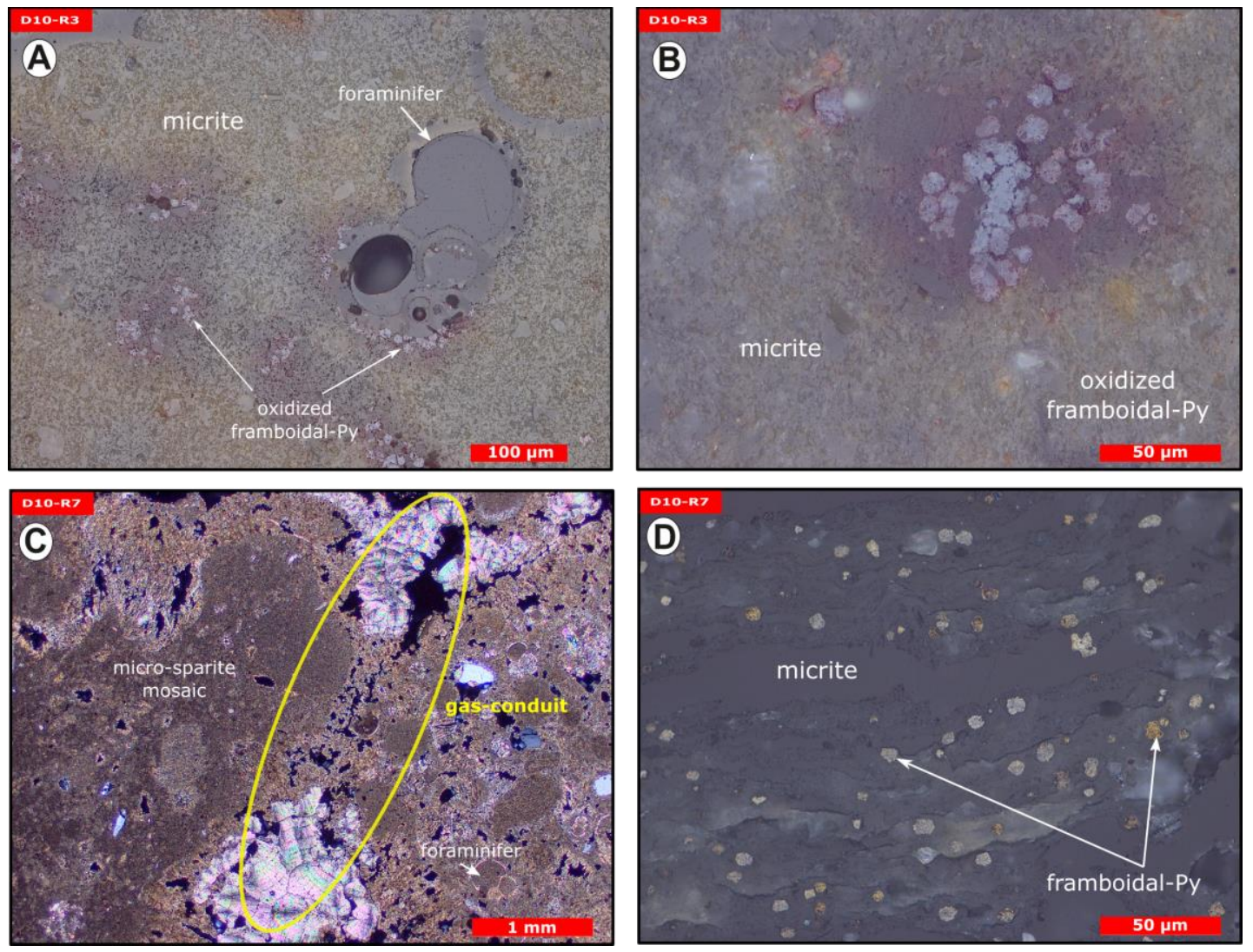

Figure 8: Thin section photographs of MDACs. A-B: D10-R3 consisting of a micritic matrix with scattered foraminifers and oxidized framboidal pyrites (reflected light); C-D: D10-R7 consisting of micritic and micro-sparitic carbonate with abundant unaltered framboidal pyrites $(\mathrm{C}$, transmitted light; $\mathrm{D}$, reflected light). Please note open voids which represent potential pathways for fluid seepage (yellow circle in $\mathrm{C}$ ).

Sample D11-R8 stems from an area with meter-sized carbonate blocks at the summit of the $\mathrm{Al} \mathrm{Gacel} \mathrm{MV} \mathrm{and} \mathrm{is} \mathrm{mainly} \mathrm{colonized} \mathrm{by} \mathrm{sponges} \mathrm{and} \mathrm{worms} \mathrm{(Fig.} \mathrm{4,} \mathrm{D).} \mathrm{The}$ sample generally exhibits a light grey mud- to wackestone texture consisting of allomicrite with few scleractinian-coral fragments and planktonic foraminifers (Fig. 7, E-F). The carbonate furthermore contains abundant quartz silt and, locally, pyrite enrichments. A further prominent feature are voids that are encircled by dark grey halos and exhibit brownish margins (due to enrichments of very small pyrite crystals and organic matter, respectively). $\delta^{13} \mathrm{C}$ signatures of the matrix and cements range from -14.82 to $-14.74 \%$, while embedded coral fragments exhibit $\delta^{13} \mathrm{C}$ values of 
-4.91 to $-2.99 \%$ (Fig. 7, F; Table 2 ). $\delta^{18} \mathrm{O}$ values generally range from +1.49 to +5.60 \% (Fig. 9; Table 2).

Sample D03-B1 is a necrotic fragment of a living scleractinian coral (Madrepora oculata) recovered from the Northern Pompeia Coral Ridge (Fig. 6, D; Fig. 7, G). The coral-carbonate exhibits $\delta^{13} \mathrm{C}$ values ranging from -8.08 to $-1.39 \%$ and $\delta^{18} \mathrm{O}$ values from -0.31 to $+2.26 \%$ (Fig. 9; Table 2).

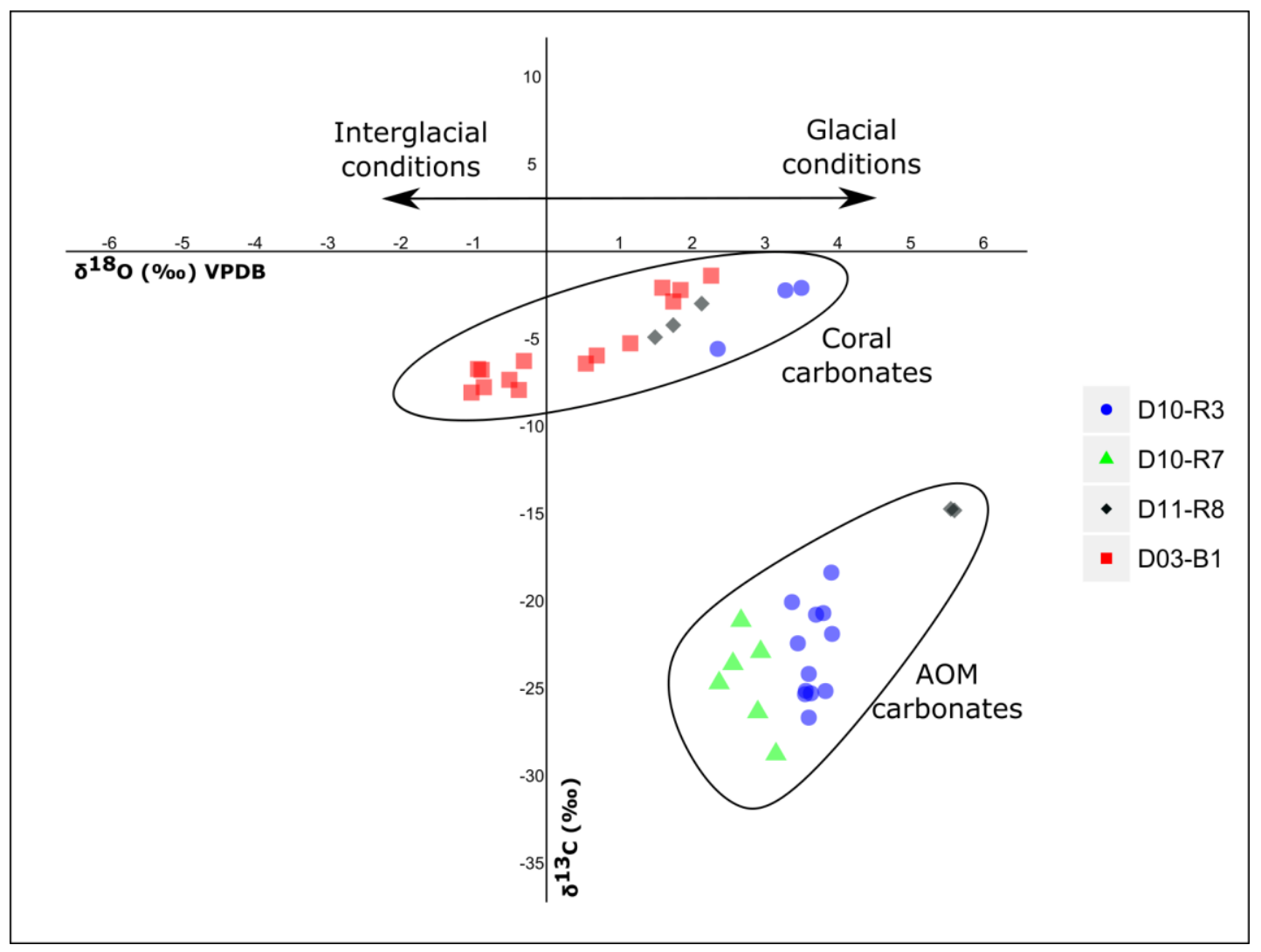

Figure 9: Stable carbon and oxygen isotopes $\left(\delta^{13} \mathrm{C}, \delta^{18} \mathrm{O}\right)$ of samples from the $\mathrm{Al} \mathrm{Gacel} \mathrm{MV}$ and the Northern Pompeia Coral Ridge (see Figure 3 for precise sampling points).

\subsubsection{Lipid biomarkers and compound specific isotope signatures}

The hydrocarbon fractions of the sample D10-R7 mainly consist of the irregular, tailto-tail linked acyclic isoprenoids 2,6,11,15-tetramethylhexadecane $\left(\mathrm{C}_{20}\right.$; crocetane), 2,6,10,15,19-pentamethylicosane $\left(\mathrm{C}_{25} ; \mathrm{PMI}\right)$, as well as of several unsaturated homologues of these compounds (Fig. 10). Additionally, it contains the regular, head- 
to-tail linked acyclic isoprenoid pristane $\left(\mathrm{C}_{19}\right)$ and the cyclic isoprenoid hop-17(21)ene.

The hydrocarbon fraction of sample D11-R8 is dominated by $n$-alkanes with chainlengths ranging from $\mathrm{C}_{14}$ to $\mathrm{C}_{28}$ (maxima at $n$ - $\mathrm{C}_{16}$ and, subordinated, at $n$ - $\mathrm{C}_{20}$ and $n$ $\mathrm{C}_{28}$ ) (Fig. 10). The sample further contains pristane, crocetane, the head-to-tail linked acyclic isoprenoid phytane $\left(\mathrm{C}_{20}\right)$ and traces of PMI.

Crocetane and PMI exhibited strongly depleted $\delta^{13} \mathrm{C}$ values in sample D10-R7 $(-101.2$ $\%$ and $-102.9 \%$, respectively), while they showed less depleted $\delta^{13} \mathrm{C}$ values in sample D11-R8 (-57.2 \%o and $-74.3 \%$, respectively). $\Delta{ }^{13} \mathrm{C}$ values of $n$-alkanes in sample D11-R8 ( $\left.n-\mathrm{C}_{17-22}\right)$ ranged between $-30.8 \%$ and $-33.0 \%$ (Table 3).

Table 3. Stable carbon isotopic composition $\left(\delta^{13} \mathrm{C}\right)$ of selected lipid biomarkers (in Figure 10). $(*)$ Please note that crocetane in D11-R8 coelutes with phytane. n.d. = not detected.

\begin{tabular}{|c|c|c|}
\hline Compound & $\begin{array}{c}\text { D10-R7 } \\
\text { (\%o) }\end{array}$ & $\begin{array}{c}\text { D11-R8 } \\
\text { (\%o) }\end{array}$ \\
\hline$n-\mathrm{C}_{17}$ & n.d. & -33.0 \\
$n-\mathrm{C}_{18}$ & n.d. & -31.8 \\
$n-\mathrm{C}_{19}$ & n.d. & -31.1 \\
$n-\mathrm{C}_{20}$ & n.d. & -30.8 \\
$n-\mathrm{C}_{21}$ & n.d. & -31.5 \\
$n-\mathrm{C}_{22}$ & n.d. & -31.7 \\
Crocetane* & -101.2 & -57.2 \\
PMI & -102.9 & -74.3 \\
\hline
\end{tabular}




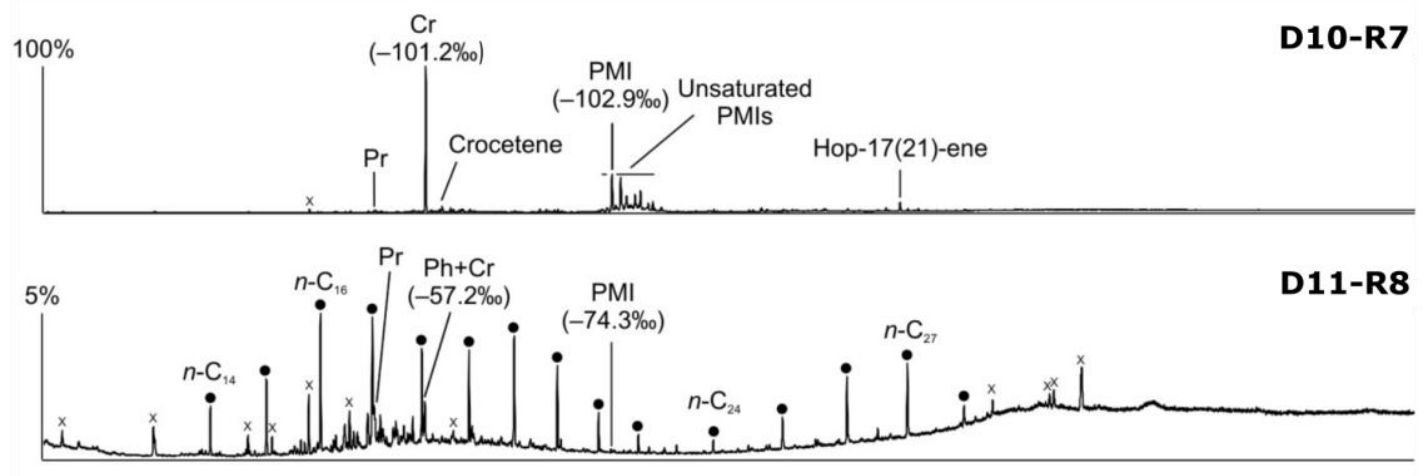

Figure 10: Total ion current (TIC) chromatograms of the analyzed samples. Isotopically depleted acyclic irregular isoprenoids such as $\mathrm{Cr}$ and PMI are typically found in settings influenced by the anaerobic oxidation of methane $(\mathrm{AOM}) . \mathrm{Pr}=$ pristane; $\mathrm{Ph}=$ phytane; $\mathrm{Cr}=$ crocetane; $\mathrm{PMI}=$ 2,6,10,15,19-pentamethylicosane; dots = n-alkanes; crosses = siloxanes (septum or column bleeding). Percentage values given on the vertical axes of chromatograms relate peak intensities to highest peak (Cr in D10-R7).

\subsubsection{DNA inventories (MiSeq Illumina sequences)}

Bacterial DNA (Fig. 11, A) from samples D10-R3 (authigenic carbonate, base of the Al Gacel MV) and D03-B1 (Madrepora oculata fragment, Northern Pompeia Coral Ridge) mainly derives from taxa that typically thrive in the water-column (e. g. Actinobacteria, Acidobacteria, Chloroflexi, Bacteroidetes, Woeseiaceae, Dadabacteria, Kaiserbacteria, Poribacteria, Planctomycetes, Gemmatimonadetes). The sample D10R3 furthermore contains bacterial DNA of the nitrite-oxidizing bacteria Nitrospira sp., while the sample D03-B1 contains DNA of the bacterial taxa Verrucomicrobia, Enterobacteria, Nitrosococcus. Noteworthy, one amplicon sequence variant (ASV_189) with low number of clustered sequences has been found in D03-B1, identified as a methanotrophic symbiont of Bathymodiolus mauritanicus (see Rodrigues et al., 2013).

Up to $50 \%$ of bacterial DNA in sample D10-R7 (authigenic carbonate, top of the Al Gacel MV) derives from taxa that are commonly associated with fluid seepage and $\mathrm{AOM}$, i.e. sulfide-oxidizing bacteria, sulfate-reducing bacteria (SRB) and methaneoxidizing bacteria. The most abundant are SRB taxa like SEEP-SRB1, SEEP-SRB2, 
Desulfatiglans, Desulfobulbus and Desulfococcus, which typically form consortia with ANME archaea.

Archaeal DNA (Fig. 11, B) from samples D10-R3 and D03-B1 mainly consist of Cenarchaeum sp., which represents $70-90 \%$. Candidatus Nitrosopumilus is the second most abundant in both samples, representing 5-20\%. On the contrary, around $90 \%$ of archaeal DNA in D10-R7 is related to ANME-1 and ANME-2 groups, in good concordance with the relative abundances of SRB DNA.

Details of the number of reads per taxa are shown in the supplementary data, Tables 1 and 2. 

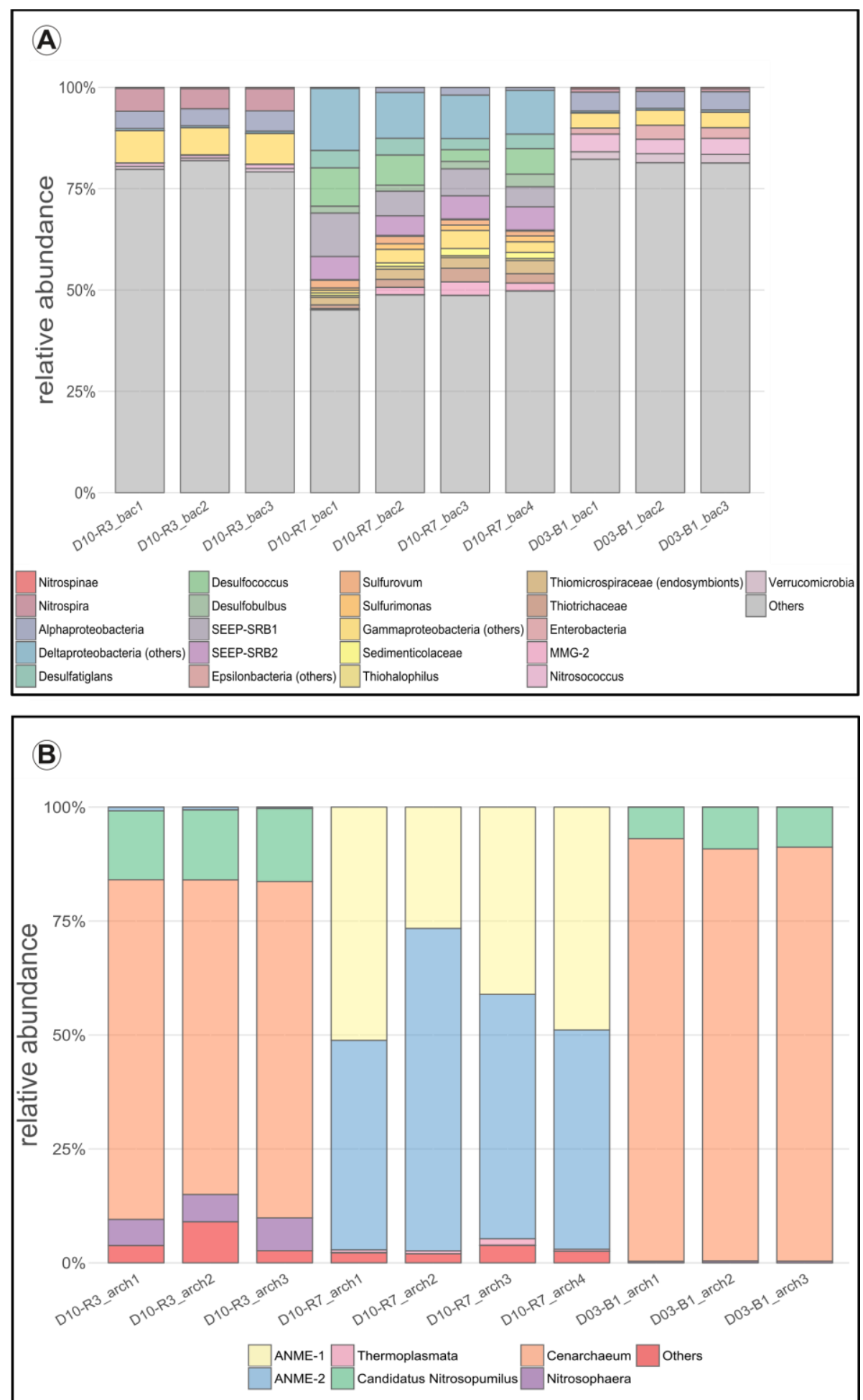

Figure 11: Bar chart representing the different taxa found in each sample according to relative abundances. A: bacterial taxa; B: archaeal taxa. In "others" aggrupation is included taxa related to ubiquitous organism normally found in sea- and seepage-related environments, and unclassified organisms. Number of reads per taxa detailed in Table S1 (bacteria) and Table S2 (archaea). 


\subsection{Discussion}

\subsubsection{Evidence of hydrocarbon-rich seepage affecting the Pompeia Province}

2D multichannel-seismic images show that the Pompeia Province is affected by fluid expulsion related to compressional diapiric ridges and thrust faults (Fig. 3, B), as it has been reported from other areas of the Gulf of Cádiz (Somoza et al., 2003; Van Rensbergen et al., 2005; Medialdea et al., 2009). There seem to be different types of fault-conduit systems that link the overpressure zones (OP) with the seafloor (Fig. 3, B), controlling both type and rate of seepage (e.g. eruptive, focused, diffused or dripping-like). At the $\mathrm{Al}$ Gacel MV, conduits are for instance mainly linked to faults and a dense hydro-fracture network, allowing the migration of hydrocarbon-rich muds from the overpressure zone to the surface. During active episodes, eruptions lead to the formation of mud-breccia flows as observed in gravity cores (e.g. León et al., 2012). During rather dormant episodes, focused and dripping-like seepage predominates, forming pockmark features (Fig. 4, B).

Currently, the Al Gacel MV is affected by continuous and focused dripping-like seepages. These sites of active seepage are characterized by carbonates that are suspected to be methane-derived (e.g. sample D10-R7, Fig. 4, B-C). In-situ ROVmeasurements and subsequent water sample analysis demonstrated high proportions of $\mathrm{CH}_{4}$ in fluids that were escaping upon removal of the D10-R7 carbonate $(171 \mathrm{nM}$; Fig. 5, A) (Sánchez-Guillamón et al., 2015). This association suggests a genetic relationship between hydrocarbon-rich seepage and the carbonate, as also evidenced by the low $\delta^{13} \mathrm{C}$-values of the carbonates analyzed herein (down to ca. $-30 \%$, Fig. 9; Table 2). Indeed, the grey peloidal texture of this sample resembles that of AOMderived automicrites from the Black Sea that are related to micro-seepage of methane (cf. Reitner et al., 2005). The here observed isotopically depleted acyclic isoprenoids such as crocetane and PMI $\left(\delta^{13} \mathrm{C}\right.$ values between ca. -103 and $-57 \%$; Fig. 10; Table 3) are typical fingerprints of AOM-associated Archaea (Hinrichs et al., 1999; Thiel et al., 1999, 2001; Peckmann et al., 2001; Peckmann \& Thiel, 2004), which is also in good accordance with the high abundance of DNA related to ANME. At the same time, 
abundant framboidal pyrite in the carbonate (Fig. 8, C-D) and SRB-related DNA (Fig. 11) evidences microbial sulfate reduction in the environment. All these evidences clearly demonstrate that the carbonates have been formed via AOM, fueled by fluids from the underlying mud diapir.

Other carbonate samples from the Al Gacel MV (i.e. D10-R3 and D11-R8) probably have also been formed due to AOM as they are also isotopically depleted $\left(\delta^{13} \mathrm{C}\right.$ values between ca. -25 and $-15 \%$, Fig. 9, Table 2). However, no active gas bubbling was observed during sampling, even though both samples still contain open voids which could form pathways for a continuous migration of fluids. In fact, several characteristics of these voids (e.g. dark halos formed by pyrite, brownish margins due to organic matter enrichments) are very similar to those of methane-derived carbonate conduits (cf. Reitner et al., 2005). This could imply that the intensity of hydrocarbonrich seepage and consequently AOM, may have fluctuated through time. The relatively low dominance of crocetane and PMI in sample D11-R8 (Fig. 10), as well as their moderately depleted $\delta^{13} \mathrm{C}$ values ( $-57.2 \%$ and $-74.3 \%$, respectively; Table 3 ), could be due to mixing effects and thus be in good accordance varying intensities of AOM in the environment. Also, the presence of only few AOM-related DNA sequences (Fig. 11) and partly oxidized pyrites in sample D10-R3 (Fig. 8, A-B) are well in line with this scenario. In concert it appears that the seepage intensity has indeed been fluctuating.

There is no evidence for eruptive extrusions of muddy materials at the coral ridges. In the Southern Pompeia Coral Ridge (Fig. 3), diapirs appears to rather promote an upward migration of hydrocarbon-rich fluids in a divergent way throughout a more extensive seabed area. This results in a continuous and diffused seepage, which promotes the occurrence of $\mathrm{AOM}$ and the formation of MDACs at the base of the ridges, related to the sulphate-methane transition zone (SMTZ) (Boetius et al., 2000; Hinrichs and Boetius, 2002; González et al., 2012a). This is in good accordance with the detection of methane $(80-83 \mathrm{nM})$ at the Northern Pompeia Coral Ridge and the presence of sulfide-oxidizing bacterial mats and shells of dead chemosynthetic bivalves at the western part of the ridge (Fig. 6, A). Likewise, the CWC Mounds Field 
surrounding the Southern Pompeia Coral Ridge (Fig. 3) is thoroughly characterized by micro-seeps, due to ascending fluids from OPs through low-angel faults. This type of focused seepage may promote formation of MDAC pavements in deeper layers of the sediments (Fig. 3), similar to coral ridges along the Pen Duick Escarpment (Wehrmann et al., 2011). The generation of MDAC-hotspots at sites of such seepage also explain the geometry of the downward tapering cones (Fig. 3).

\subsubsection{Ecological meaning of hydrocarbon-rich seepage for CWCs}

Our data suggests contemporaneous micro-seepage and CWC growth in the Pompeia Province (e.g. Fig. 4, B). This relationship has also been observed elsewhere, e.g. in North Sea and off Mid Norway (Hovland, 1990; Hovland \& Thomsen, 1997), and the Angola margin (Le Guilloux et al., 2009). However, scleractinian fragments recovered from the Al Gacel MV (embedded in carbonates D10-R3 and D11-R8) and the Northern Pompeia Coral Ridge (D03-B1, necrotic part of a living Madrepora oculata) displayed barely depleted $\delta^{13} \mathrm{C}$ values (ca. -8 to $-1 \%$; Fig. 9; Table 2), close to the $\delta^{13} \mathrm{C}$ of marine seawater $(0 \pm 3 \%$, e.g. Hoefs, 2015). This does not support a significant uptake of methane-derived carbon by the CWCs and thus a direct trophic dependency as previously proposed (Hovland, 1990). Furthermore, the only DNA in sample D03-B1 that could be attributed to a potential methanotrophic endosymbiont (ASV_189: Rodrigues et al., 2013) occurred in minor amounts and most likely represents contamination from the environment or during sampling. Taken together, there is no evidence that CWCs in the working area harbor microbial symbionts which potentially could utilize the hydrocarbon-rich fluids. More likely, the CWCs feed on a mixture of phytoplankton, zooplankton and dissolved organic matter as previously proposed for ones in other regions (Kiriakoulakis et al., 2005; Duineveld et al., 2007; Becker et al., 2009; Liebetrau et al., 2010). This is in good accordance with the presence of DNA from various common archaeal and bacterial taxa (e.g. Acidobacteria, Actinobacteria, Candidatus Nitrosopumilus, Cenarchaeum sp.) and some potential members of the corals' holobiont (e.g. Enterobacteria, 
Verrucomicrobia, Nitrosococcus sp.) (Sorokin, 1995; Rädecker et al., 2015; Webster et al., 2016) in sample D03-B1 (Fig. 11).

CWC development and hydrocarbon-rich seepage are consequently linked via the formation of MDAC deposits, which provide the hard substrata needed for CWC larval settlement (e.g. Díaz-del-Rio et al., 2003; Van Rooij et al., 2011; Magalhães et al., 2012; Le Bris et al., 2016; Rueda et al., 2016). If too severe, however, fluid flow and associated metabolic processes can result in local conditions that are lethal to CWCs (see 4.3). Moreover, AOM fueled by fluid flow can also cause an entombment of the CWCs by MDACs (Wienberg et al., 2009, Wienberg \& Titschack, 2015), as observed in D10-R3 and D11-R8 carbonates from the Al Gacel MV (Figs. 7 and 9; Tabs. 2 and

3). It is therefore not surprising that large CWC systems in the Pompeia Province are always linked to structures that are affected by rather mild, non-eruptive seepage (i.e. the extinct MV, the coral ridges and the CWC Mound Fields: Figs. 3 and 6). The observation that these systems are in large parts "coral graveyards" (Fig. 6, B-D), similar to other areas in the Gulf of Cádiz (see Foubert et al., 2008; Wienberg et al., 2009), may be explained by a post-glacial decrease in current strength (Foubert et al., 2008). In the light of our findings, however, they could also have been negatively affected by periods of intensive seepage during higher tectonic activity. Future studies are important to test this hypothesis in greater detail.

\subsubsection{Spatio-temporal co-existence of CWCs and chemosynthetic organisms - the buffer effect}

As discussed above, MDAC deposits are ecologically beneficial for CWCs, as they served as optimal substrata even when seepage is still present (e. g. Hovland, 1990; Hovland \& Thomsen, 1997; Le Guilloux et al., 2009; this study). Severe hydrocarbonrich seepage, however, is ecologically stressful for the corals. Particularly, fluid- and AOM-derived hydrogen sulfide is considered problematic because of its role in coral necrosis (Myers \& Richardson, 2009; García et al., 2016) and carbonate dissolution effects (Wehrmann et al., 2011). 
Hydrogen sulfides can efficiently be buffered through the reaction with $\mathrm{Fe}$ (oxyhydro)-oxides or $\mathrm{Fe}^{2+}$ dissolved in pore waters, ultimately forming pyrite (Wehrmann et al., 2011). Fe-(oxyhydro)-oxides nodules have previously been observed in the Iberian and Moroccan margins (González et al., 2009; 2012b), but not in the Pompeia Province. Instead, sulfide-oxidizing bacteria living in symbiosis with invertebrates (e.g. siboglinid worms: Petersen \& Dubilier, 2009) (Fig. 5, D) and thriving in mats (Fig. 4, C; Fig. 6, A) were particularly prominent along this region. Furthermore, the consumption of methane and sulfate by AOM-microorganisms at active sites also contribute to CWCs colonization of the carbonates by reducing environmental acidification.

An integrated model is proposed to represent the biological buffer effect observed in different cases along the Pompeia Province. On the one hand, pockmark sites at the $\mathrm{Al}$ Gacel MV display the co-existence of non-chemosynthetic corals (e.g. on top of D10R7 carbonate; Fig. 5) with AOM-microorganisms and chemosynthetic sulfideoxidizing organisms (Fig. 12, A). Likewise, diapiric ridges (Fig. 12, B) and coral mounds (Fig. 12, C) may similarly prevent CWCs dissolution, as observed in the Northern Pompeia Coral Ridge, where sulfide-oxidizing bacterial mats were tightly related to the scleractinian-coral carbonates colonized by other non-chemosynthetic octocorals (Fig. 6). This model represents the first approach on understanding the ecological linkage between hydrocarbon-rich seepage and cold-water corals. The impact and exact capacity of this biological buffer, however, remains elusive and must be evaluated in future studies. 


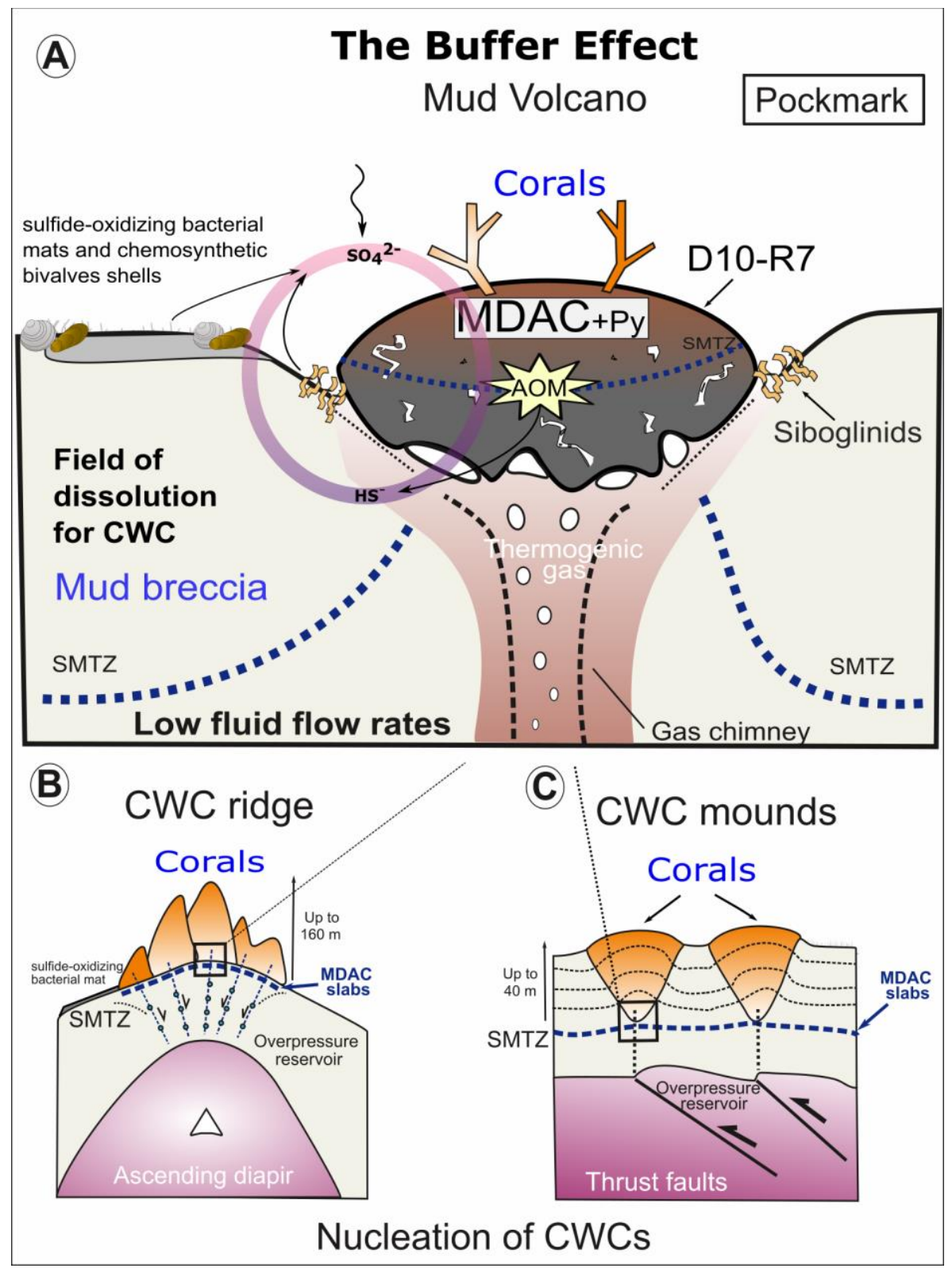

Figure 12: The buffer effect model. A: Buffer effect at pockmark sites (e.g. sampling site of D10-R7) where carbonates are formed directly on the bubbling site acting as a cap; B: Buffer effect at diapiric ridges where MDAC slabs are formed on the base of the ridge; $\mathbf{C}$ : Buffer effect at coral mounds where MDAC slabs are formed in deeper layers of the sediment. Py = pyrite, SMTZ: sulfur-methane transition zone. 


\subsection{Conclusions}

The presence of cold-water corals related to hydrocarbon-seep structures like mud volcanoes and diapirs, is partly due to the irregular topography affecting bottom watercurrents, which supply nutrients to the corals. Likewise, their tight-linkage to active hydrocarbon-rich seepage occurs by means of the production of methane-derived carbonates and how they provide the hard substrata cold-water corals need to develop. The discovery of methane-derived carbonates with embedded corals evidences the decline of coral colonization when the intensity of the fluid seepage increases or becomes more violent. Consequently, cold-water coral growth in these habitats depends directly on seepage intensity and how these fluids are drained onto the seafloor (i.e. eruptive, focused, diffused or dripping-like). Furthermore, cold-water corals rely on the microbial AOM-metabolism and sulfide oxidation to reduce seeped fluids in the environment, since they are harmful for the corals. This biological buffer is possibly crucial to keep conditions favorable for the growth of cold-water corals in the studied area, particularly in times of increased fluid seepage.

\subsection{References}

Ahmed, M. and George, S.C.: Changes in the molecular composition of crude oils during their preparation for GC and GC-MS analyses, Org. Geochem., 35, 137-155, doi:10.1016/j.orggeochem.2003.10.002, 2004.

Becker, E. L., Cordes, E. E., Macko, S. A., and Fisher, C. R.: Importance of seep primary production to Lophelia pertusa and associated fauna in the Gulf of Mexico, Deep-sea Res Pt I, 56(5), 786-800, doi:10.1016/j.dsr.2008.12.006, 2009.

Birgel, D., Thiel, V., Hinrichs, K. U., Elvert, M., Campbell, K. A., Reitner, J., Farmer, J. D., and Peckmann, J.: Lipid biomarker patterns of methane-seep microbialites from the Mesozoic convergent margin of California, Org. Geochem., 37(10), 1289-1302, doi:10.1016/j.orggeochem.2006.02.004, 2006. 
Boetius, A., Ravenschlag, K., Schubert, C. J., Rickert, D., Widdel, F., Gieseke, A., Amann, R., Jørgensen, B. B., Witte, U., and Pfannkuche, O.: A marine microbial consortium apparently mediating anaerobic oxidation of methane, Nature, 407 (6804), 623-626, doi:10.1038/35036572, 2000.

Boetius, A., and Suess, E.: Hydrate Ridge: a natural laboratory for the study of microbial life fueled by methane from near-surface gas hydrates, Chem. Geol., 205, 291-310, doi:10.1016/j.chemgeo.2003.12.034, 2004.

Callahan, B., MacMurdie, P. J., and Holmes, S. O.: Exact sequence variants should replace optional taxonomic units in marker-gene data analysis, ISME J., 11, 2639-2643, doi:10.1038/ismej.2017.119, 2017.

Caporaso, J.G., Kuczynski, J., Stombaugh, J., Bittinger, K., Bushman, F.D., Costello, E.K., Fierer, N., González-Peña, A., Goodrich, J. K., Gordon, J. I., Huttley, G. A., Knights, D., Koenig, J. E., Lozupone, C. A., McDonald, D., Muegge, B. D., Pirrung, M., Reeder, J., Sevinsky, J. R., Turnbaugh, P. J., Walters, W. A., Widmann, J., Yatsunenko, T., Zaneveld, J., and Knight, R.: QIIME allows analysis of high-throughput community sequencing data, Nat. Methods, 7, 335-336, doi:10.1038/nmeth.f.303, 2010.

Cordes, E., Arnaud-Haond, S., Bergstad, O., da Costa Falcão, A. P., Freiwald, A., Roberts, J. M., and Bernal, P.: Cold water corals, in: The First Global Integrated Marine Assessment, World Ocean Assessment I, United Nations, Cambridge University Press, Cambridge, United Kingdom, 2016.

Díaz-del-Río, V., Somoza, L., Martínez-Frías, J., Mata, M. P., Delgado, A., Hernandez-Molina, F. J., ..., Vázquez, J. T.: Vast fields of hydrocarbonderived carbonate chimneys related to the accretionary wedge/olistostrome of the Gulf of Cádiz, Mar. Geol., 195, 177-200, doi:10.1016/S00253227(02)00687-4, 2003.

Dorschel, B., Hebbeln, D., Foubert, A., White, M., and Wheeler, A. J.: Hydrodynamics and cold-water coral facies distribution related to recent sedimentary processes at Galway Mound west of Ireland, Mar. Geol., 244, 184-195, doi:10.1016/j.margeo.2007.06.010, 2007. 
Duineveld, G. C., Lavaleye, M. S., Bergman, M. J., De Stigter, H., and Mienis, F.: Trophic structure of a cold-water coral mound community (Rockall Bank, NE Atlantic) in relation to the near-bottom particle supply and current regime, B. Mar. Sci., 81 (3), 449-467, 2007.

Dullo, W. C., Flögel, S., and Rüggerberg, A.: Cold-water coral growth in relation to the hydrography of the Celtic and Nordic European continental margin, Mar. Ecol. Prog. Ser., 371, 165-176, doi:10.3354/meps07623, 2008.

Dunham, R. J., 1962, Classification of carbonate rocks according to their depositional texture, in: Classification of Carbonate Rocks, Ham, W. E. (Eds.), American Association of Petroleum Geologists Memoir 1, Tulsa, OK, 108-121, 1962.

Edgar, R. C.: USEARCH. http://www.drive5.com/usearch. 2010.

Egelkamp, R., Schneider, D., Hertel, R., and, Daniel, R.: Nitrile-Degrading Bacteria Isolated from Compost, Front. Environ. Sci., 5, doi: 10.3389/fenvs.2017.00056, 2017.

Embry III, A. F., and Klovan, J. E.: A late Devonian reef tract on northeastern Banks Island, NWT, B. Can. Petrol. Geol., 19(4), 730-781, 1971.

Foubert, A., Depreiter, D., Beck, T., Maignien, L., Pannemans, B., Frank. N., Blamart, D., and Henriet, J.: Carbonate mounds in a mud volcano province off northwest Morocco: key to processes and controls, Mar. Geol., 248, 74-96, doi: 10.1016/j.margeo.2007.10.012, 2008.

Frank, N., Freiwald, A., López-Correa, M., Wienberg, C., Eisele, M., Hebbeln, D., Van Rooj, D., Henriet, J.-P., Colin, C., van Weering, T., de Haas, H., BuhlMortensen, P., Roberts, J. M., De Mol, B., Douville, E., Blamart, D., and Hatté, C.: Northeastern Atlantic cold-water coral reefs and climate, Geology, 39 (8), 743-746, doi:10.1130/G31825.1, 2011.

Freiwald, A., Hühnerbach, V., Lindberg, B., Wilson, J., and Campbell, J.: The Sula Reef Complex, Norwegian Shelf, Facies, 47, 179-200, doi:10.1007/BF02667712, 2002. 
Freiwald, A.,Wilson, J. B., and Henrich, R.: Grounding Pleistocene icebergs shape recent deep water coral reefs, Sedimentary Geology 125, 1-8, doi:10.1016/S0037-0738(98)00142-0, 1999.

Garcia, G. D., Santos, E. D. O., Sousa, G. V., Zingali, R. B., Thompson, C. C., and Thompson, F. L.: Metaproteomics reveals metabolic transitions between healthy and diseased stony coral Mussismilia braziliensis, Mol. Ecol., 25(18), 4632-4644, doi:10.1111/mec.13775, 2016.

Gomes-Sumida, P.Y., Yoshinaga, M.Y., Saint-Pastous Madureira, L.A., and Hovland, M.: Seabed pockmarks associated with deep water corals off SE Brazilian continental slope, Santos Basin, Mar. Geol., 207, 159-167, doi:10.1016/j.margeo.2004.03.006, 2004.

González, F. J., Somoza, L., Lunar, R., Martínez-Frías, J., Martín Rubí, J. A., Torres, T., Ortiz, J. E., Díaz-del-Río, V., Pinheiro, L. M., and Magalhães, V. H.: Hydrocarbon-derived ferromanganese nodules in carbonate mud mounds from the Gulf of Cádiz: mud-breccia sediments and clasts as nucleation sites, Mar. Geol., 261, 64-81, doi:10.1016/j.margeo.2008.11.005, 2009.

González, F. J., Somoza, L., León, R., Medialdea, T., de Torres, T., Ortiz, J. E., Martínez-Frías, J., and Merinero, R.: Ferromanganese nodules and microhardgrounds associated with the Cádiz Contourite Channel (NE Atlantic): Palaeoenvironmental records of fluid venting and bottom currents, Chem. Geol., 310-311, 56-78, doi: 10.1016/j.chemgeo.2012.03.030, 2012a.

González, F. J., Somoza, L., Medialdea, T., León, R., Torres, T., Ortiz, J. E., and Martín-Rubí, J. A.: Discovery of ferromanganese hydrocarbon-related nodules associated with the Meknes mud volcano (Western Moroccan margin). European Geoscience Union 2012 (EGU2012). Viena (Austria). Geophys. Res. Abs. vol. 14, EGU2012-12306, 2012 b.

Hebbeln, D., Van Rooij, D., and Wienberg, C.: Good neighbours shaped by vigorous currents: cold-water coral mounds and contourites in the North Atlantic, Mar. Geol, 378, 171-185, doi:10.1016/j.margeo.2016.01.014, 2016. 
Hensen, C., Nuzzo, M., Hornibrook, E., Pinheiro, L.M., Bock, B., Magalhães, V.H., and Brückmann, W.: Sources of mud volcano fluids in the Gulf of Cádiz indications for hydrothermal imprint, Geochim. Cosmochim. Ac., 71 (5), 1232-1248, doi:10.1016/j.gca.2006.11.022, 2007.

Hinrichs, K. -U., and Boetius, A.: The anaerobic oxidation of methane: new insights in microbial ecology and biogeochemistry, in: Ocean Margin Systems, Wefer, G., Billett, D., Hebbeln, D., Jørgensen, B.B., Schlueter, M., Van Weering, T. (Eds.), Springer-Verlag, Berlin, 457-477, 2002.

Hinrichs, K. -U., Hayes, J. M., Sylva, S. P., Brewer, P. G., and De Long, E. F.: Methane-consuming archaebacteria in marine sediments, Nature, 398, 802805, doi:10.1038/19751, 1999.

Hoefs, J.: Stable Isotope Geochemistry, Springer, Berlin, 2015.

Hovland, M.: Do carbonate reefs form due to fluid seepage?, Terra Nova, 2, 8-18, doi:10.1111/j.1365-3121.1990.tb00031.x, 1990.

Hovland, M., Jensen, S., and Indreien, T.: Unit pockmarks associated with Lophelia coral reefs off mid-Norway: more evidence of control by 'fertilizing' bottom currents, Geo-Mar. Lett., 32 (5-6), 545-554, doi:10.1007/s00367-012-0284-0, 2012.

Hovland, M., Mortensen, P. B., Brattegard, T., Strass, P., and Rokoengen, K.: Ahermatypic coral banks off mid-Norway: evidence for a link with seepage of light hydrocarbons, Palaios, 13, 189-200, doi:10.1043/08831351(1998)013<0189:ACBOME>2.0.CO;2, 1998.

Hovland, M., and Thomsen, E.: Cold-water corals - are they hydrocarbon seep related?, Mar. Geol., 137, 159-164, doi:10.1016/S0025-3227(96)00086-2, 1997.

Huvenne, V. A., Masson, D. G., and Wheeler, A. J.: Sediment dynamics of a sandy contourite: the sedimentary context of the Darwin cold-water coral mounds, Northern Rockall Trough, Int. J. Earth Sci., 98 (4), 865-884, doi: 10.1007/s00531-008-0312-5, 2009. 
Ivanov, M. K., Akhmetzhanov, A. M., and Akhmanov, G. G.: Multidisciplinary study of geological processes on the North East Atlantic and Western Mediterranean Margins, in: Ioc. Tech. S., 56, UNESCO, 2000.

Kiriakoulakis, K., Fisher, E., Wolff, G. A., Freiwald, A., Grehan, A., and Roberts, J. M.: Lipids and nitrogen isotopes of two deep-water corals from the North-East Atlantic: initial results and implications for their nutrition, in: Cold-Water Corals and Ecosystems, Freiwald, A., Roberts, J. M. (Eds.), Erlangen Earth Conf., Springer, Germany, 715-729, 2005.

Le Bris, N., Arnaud-Haond, S., Beaulieu, S., Cordes, E. E., Hilario, A., Rogers, A., van de Gaever, S., and Watanabe, H.: Hydrothermal Vents and Cold Seeps, in: The First Global Integrated Marine Assessment, United Nations, Cambridge University Press, Cambridge, United Kingdom, 2016.

Le Guilloux, E., Olu, K., Bourillet, J. F., Savoye, B., Iglésias, S. P., and Sibuet, M.: First observations of deep-sea coral reefs along the Angola margin, Deep-sea Res. Pt. II, 56, 2394-2403, doi:10.1016/j.dsr2.2009.04.014, 2009.

Liebetrau, V., Eisenhauer, A., and Linke, P.: Cold seep carbonates and associated coldwater corals at the Hikurangi Margin, New Zealand: new insights into fluid pathways, growth structures and geochronology, Mar. Geol., 272, 307-318, doi:10.1016/j.margeo.2010.01.003, 2010.

León, R., Somoza, L., Medialdea, T., Vázquez, J. T., González, F. J., López-González, N., Casas, D., del Pilar Mata, M., del Fernández-Puga, C., Giménez-Moreno, C. J., and Díaz-del-Río, V.: New discoveries of mud volcanoes on the Moroccan Atlantic continental margin (Gulf of Cádiz): morpho-structural characterization, Geo-Mar. Lett., 32, 473-488, doi:10.1007/s00367-012-0275$1,2012$.

Magalhães, V. H., Pinheiro, L. M., Ivanov, M. K., Kozlova, E., Blinova, V., Kolganova, J., Vasconcelos, C., McKenzie, J. A., Bernasconi, S. M., Kopf, A., Díaz-del-Río, V., González, F. J., and Somoza, L.: Formation processes of methane-derived authigenic carbonates from the Gulf of Cádiz, Sediment. Geol., 243-244, 155-168, doi:10.1016/j.sedgeo.2011.10.013, 2012. 
Margreth, S., Gennari, G., Rüggeberg, A., Comas, M. C., Pinheiro, L. M., and Spezzferri, S.: Growth and demise of cold-water coral ecosystems on mud volcanoes in the West Alboran Sea: The messages from planktonic and benthic foraminifera, Mar. Geol., 282, 26-39, doi:10.1016/j.margeo.2011.02.006, 2011.

Martin, M.: Cutadapt removes Adapter Sequences from High-Throughput Sequencing Reads, EMBnet.jounal, 10-12, doi: 10.14806/ej.17.1.200, 2011.

Medialdea, T., Somoza, L., Pinheiro, L. M., Fernández-Puga, M. C., Vázquez, J. T., León, R., Ivanov, M. K., Magalhães, V., Díaz-del-Río, V., and Vegas, R.: Tectonics and mud volcano development in the Gulf of Cádiz, Mar. Geol., 261, 48-63, doi:10.1016/j.margeo.2008.10.007, 2009.

Mortensen, P. B., Hovland, M. T., Fossa, J. H., and Furevik, D. M.: Distribution, abundance and size of Lophelia pertusa coral reefs in mid Norway in relation to seabed characteristics, J. Mar. Biol. Assoc. UK, 81, 581-597, doi:10.1017/S002531540100426X, 2001.

Myers, J.L., and Richardson, L.L.: Adaptation of cyanobacteria to the sulfide-rich microenvironment of black band disease of coral, FEMS Microbiol. Ecol., 67, 242-251, doi:10.1111/j.1574-6941.2008.00619.x, 2009.

Peckmann, J., Reimer, A., Luth, U., Luth, C., Hansen, B.T., Heinicke, C., Hoefs, J., and Reitner, J.: Methane-derived carbonates and authigenic pyrite from the northwestern Black Sea, Mar. Geol., 177, 129-150, doi:10.1016/S00253227(01)00128-1, 2001.

Peckmann, J., and Thiel, V.: Carbon cycling at ancient methane-seeps, Chem. Geol., 205 (3), 443-467, doi:10.1016/j.chemgeo.2003.12.025, 2004.

Petersen, J. M., and Dubilier, N.: Methanotrophic symbioses in marine invertebrates, Env. Microbiol. Rep., 1(5), 319-335, doi:10.1111/j.1758-2229.2009.00081.x, 2009.

Pinheiro, L. M., Ivanov, M. K., Sautkin, A., Akhmanov, G., Magalhães, V. H., Volkonskaya, A., Monteiro, J. H., Somoza, L., Gardner, J., Hamouni, N., and 
Cunha, M. R.: Mud volcanism in the Gulf of Cádiz: results from the TTR-10 cruise, Mar. Geol., 195, 131-151, doi:10.1016/S0025-3227(02)00685-0, 2003. Rädecker, N., Pogoreutz, C., Voolstra, C. R., Wiedenmann, J., and Wild, C.: Nitrogen cycling in corals: The key to understanding holobiont functioning?, Trends Microbiol., 23 (8), 490-497, doi:10.1016/j.tim.2015.03.008, 2015.

Reitner, J., Gauret, P., Marin, F., and Neuweiler, F.: Automicrites in a modern marine microbialite. Formation model via organic martices (Lizard Island, Great Barrier Reef, Australia), Bull.-Inst. Oceanogr. Monaco, 14, 237-263, 1995.

Reitner, J., Peckmann, J., Blumenberg, M., Michaelis, W., Reimer, A., and Thiel, V.: Concretionary methane-seep carbonates and associated microbial communities in Black Sea sediments, Palaeogeogr., Palaeoclimatol., Palaeocl., 227, 18-30, doi:10.1016/j.palaeo.2005.04.033, 2005.

Roberts, J. M., Long, D., Wilson, J. B., Mortensen, P. B., and Gage, J. D.: The coldwater coral Lophelia pertusa (Scleractinia) and enigmatic seabed mounds along the north-east Atlantic margin: are they related?, Mar. Pollut. Bull., 46, 7-20, doi:10.1016/S0025-326X(02)00259-X, 2003.

Roberts, J. M., Wheeler, A. J., and Freiwald, A.: Reefs of the deep: the biology and geology of cold-water coral ecosystems, Science, 312 (5773), 543-547, doi:10.1126/science.1119861, 2006.

Roberts, J. M., Wheeler, A., Freiwald, A., and Cairns, S. (Eds.): Cold-water corals: the biology and geology of deep-sea coral habitats, Cambridge University Press, Cambridge, United Kingdom, 2009.

Rodrigues, C. F., Cunha, M. R., Génio, L., and Duperron, S.: A complex picture of associations between two host mussels and symbiotic bacteria in the Northeast Atlantic, Naturwissenschaften, 100, 21-31, doi:10.1007/s00114-012-0985-2, 2013.

Rogers, A. D.: The Biology of Lophelia pertusa (Linnaeus 1758) and other DeepWater Reef-Forming Corals and Impacts from Human Activities, Int. Rev. Hydrobiol., 84 (4), 315-406, doi:10.1002/iroh.199900032, 1999. 
Rueda, J. L., González-García, E., Krutzky, C., López-Rodríguez, J., Bruque, G., López-González, N., Palomino, D., Sánchez, R. F., Vázquez, J. T., FernándezSalas, L. M., and Díaz-del-Río, V.: From chemosynthetic-based communities to cold-water corals: Vulnerable deep-sea habitats of the Gulf of Cádiz, Mar. Biodiver., 46, 473-482, doi:10.1007/s12526-015-0366-0, 2016.

Sánchez-Guillamón, O., García, M. C., Moya-Ruiz, F., Vázquez, J. T., Palomino, D., Fernández-Puga, M. C., and Sierra, A.: A preliminary characterization of greenhouse gas $\left(\mathrm{CH}_{4}\right.$ and $\left.\mathrm{CO}_{2}\right)$ emissions from Gulf of Cádiz mud volcanoes, VIII Symposium MIA15, 2015.

Scholz, F., Hensen, C., Reitz, A., Romer, R. L., Liebetrau, V., Meixner, A., Weise, S. M., and Haeckel, M.: Isotopic evidence $(87 \mathrm{Sr} / 86 \mathrm{Sr}, \delta 7 \mathrm{Li})$ for alteration of the oceanic crust at deep-rooted mud volcanoes in the Gulf of Cádiz, NE Atlantic Ocean, Geochim. Cosmochim. Ac., 73, 5444-5459, doi:10.1016/j.gca.2009.06.004, 2009.

Smith, P., Reay, D., and Van Amstel, A. (Eds.): Methane and climate change, Earthscan, London, Washington D.C., 2010.

Somoza, L., Ercilla, G., Urgorri, V., León, R., Medialdea, T., Paredes, M., González, F. J., and Nombela, M. A.: Detection and mapping of cold-water coral mounds and living Lophelia reefs in the Galicia Bank, Atlantic NW Iberia margin, Mar. Geol., 349, 73-90, doi:10.1016/j.margeo.2013.12.017, 2014.

Somoza, L., León, R., Ivanov, M. Fernández-Puga, M. C., Gardner, J. M., HernándezMolina, F. J., Pinheiro, L. M., Rodero, J., Lobato, A., Maestro, A., Vázquez, J. T., Medialdea, T., and Fernández-Salas, L. M.: Seabed morphology and hydrocarbon seepage in the Gulf of Cádiz mud volcano area: Acoustic imagery, multibeam and ultra-high resolution seismic data, Mar. Geol., 195, 153-176, doi:10.1016/S0025-3227(02)00686-2, 2003.

Sorokin, Y. I.: Coral reef ecology, Springer, Germany, 1995.

Suess, E, and Whiticar, M. J.: Methane-derived $\mathrm{CO}_{2}$ in pore fluids expelled from the Oregon subduction zone, Palaeogeogr., Palaeoclimatol., Palaeocl., 71, 119136, doi:10.1016/0031-0182(89)90033-3, 1989. 
Thiel, V., Peckmann, J., Seifert, R.,Wehrung, P., Reitner, J., and Michaelis, W.: Highly isotopically depleted isoprenoids: molecular markers for ancient methane venting, Geochim. Cosmochim. Ac., 63, 3959-3966, doi:10.1016/S00167037(99)00177-5, 1999.

Thiel, V., Peckmann, J., Richnow, H.-H., Luth, U., Reitner, J., and Michaelis, W.: Molecular signals for anaerobic methane oxidation in Black Sea seep carbonates and a microbial mat, Mar. Chem. 73, 97-112, doi:10.1016/S03044203(00)00099-2, 2001.

Thiem, Ø., Ravagnan, E., Fosså, J. H., and Berntsen, J.: Food supply mechanisms for cold- water corals along a continental shelf edge, J. Marine Syst., 26, 14811495, doi:10.1016/j.jmarsys.2005.12.004, 2006.

Valentine, D. L.: Biogeochemistry and microbial ecology of methane oxidation in anoxic environments: a review, A. Van Leeuw. J. Microb., 81, 271-282, doi:10.1023/A:1020587206351, 2002.

Vandorpe, T., Martins, I., Vitorino, J., Hebbeln, D., García-García, M., and Van Rooij, D.: Bottom currents and their influence on the sedimentation pattern in the El Arraiche mud volcano province, southern Gulf of Cádiz, Mar. Geol., 378, 114126, doi:10.1016/j.margeo.2015.11.012, 2016.

Vandorpe, T., Wienberg, C., Hebbeln, D., Van den Berghe, M., Gaide, S., Wintersteller, P., and Van Rooij, D.: Multiple generations of buried cold-water coral mounds since the Early-Middle Pleistocene Transition in the Atlantic Moroccan Coral Province, southern Gulf of Cádiz, Palaeogeogr., Palaeoclimatol., Palaeocl., 485, 293-304, doi:10.1016/j.palaeo.2017.06.021, 2017.

Van Rensbergen, P., Depreiter, D., Pannemans, B., Moerkerke, G., Van Rooij, D., Marsset, B., Akhmanov, G., Blinova, V., Ivanov, M., Rachidi, M., Magalhães, V., Pinheiro, L., Cunha, M., and Henriet, J.P.: The Arraiche mud volcano field at the Moroccan Atlantic slope, Gulf of Cádiz, Mar. Geol., 219, 1-17, doi:10.1016/j.margeo.2005.04.007, 2005. 
Van Rooij, D., Blamart, D., De Mol, L., Mienis, F., Pirlet, H., Whermann, L. M., ..., Henriet, J. -P.: Cold-water coral mounds on the Pen Duick Escarpment, Gulf of Cádiz: The MiCROSYSTEMS project approach, Mar. Geol., 282, 102-117, doi:10.1016/j.margeo.2010.08.012, 2011.

Watling, L., France, S. C., Pante, E., and Simpson, A.: Biology of Deep-Water Octocorals, in: Advances in Marine Biology Volume 60, Lesser, M. (Eds.), Academic Press, London, United Kingdom, 41-122, 2011.

Webster, N. S., Negri, A. P., Botté, E. S., Laffy, P. W., Flores, F., Noonan, S., Schmidt, C., and Uthicke, S.: Host-associated coral reef microbes respond to the cumulative pressures of ocean warming and ocean acidification Sci. Rep.-UK, 6, doi:10.1038/srep19324, 2016.

Wheeler, A. J., Beyer, A., Freiwald, A., de Haas, H., Huvenne, V. A., Kozachenko, M., Olu-Le Roy, K., and Opderbecke, J.: Morphology and environment of cold-water coral carbonate mounds on the NW European margin, Int. J. Earth Sci., 96, 37-56, doi:10.1007/s00531-006-0130-6, 2007.

Wehrmann, L. M. Templer, S. P., Brunner, B., Bernasconi, S. M., Maignien, L., and Ferdelman, T. G.: The imprint of methane seepage on the geochemical record an early diagenetic processes in cold-water coral mounds on Pen Duick Escarpment, Gulf of Cádiz, Mar. Geol., 118-137, doi:10.1016/j.margeo.2010.08.005, 2011.

Wienberg, C., Hebbeln, D., Fink, H. G., Mienis, F., Dorschel, B., Vertino, A., LópezCorrea, M., and Freiwald, A.: Scleractinian cold-water corals in the Gulf of Cádiz-first clues about their spatial and temporal distribution, Deep-sea Res. Pt. I, 56 (10), 1873-1893, doi:10.1016/j.dsr.2009.05.016, 2009.

Wienberg, C., and Titschack, J.: Framework-forming scleractinian cold-water corals through space and time: a late Quaternary North Atlantic perspective, in: Marine Animal Forests: The Ecology of Benthic Biodiversity Hotspots, Rossi, S., Bramanti, L., Gori, A., and Orejas, C. (Eds.), Springer, Cham, Switzerland, $1-34,2015$. 
Yilmaz, P., Parfrey, L.W., Yarza, P., Gerken, J., Pruese, E., Quast, C., Schweer, T., Peplies, J., Ludwig, W., and Glöckner, F. O.: The SILVA and 'All-species Living Tree Project (LTP)' taxonomic frameworks, Nucleic Acids Res., 42, D643-D648, doi:10.1093/nar/gkt1209, 2014.

Zhang, J., Kobert, K., Flouri, T., and Stamatakis, A.: PEAR: a fast and accurate Illumina Paired-End reAd merger, Bioinformatics, 30 (5), 614-620, doi:10.1093/bioinformatics/btt593, 2014. 


\subsection{Supplementary data}

Table S1: Number of reads related to different bacterial taxa found in the analyzed samples.

\begin{tabular}{|c|c|c|c|c|c|c|c|c|c|c|}
\hline Taxonomy & $\begin{array}{r}\text { D10-R3 } \\
\text { bac1 } \\
\end{array}$ & $\begin{array}{r}\text { D10-R3 } \\
\text { bac2 } \\
\end{array}$ & $\begin{array}{r}\text { D10-R3 } \\
\text { bac3 }\end{array}$ & $\begin{array}{r}\text { D10-R7 } \\
\text { bac1 } \\
\end{array}$ & $\begin{array}{r}\text { D10-R7 } \\
\text { bac2 } \\
\end{array}$ & $\begin{array}{r}\text { D10-R7 } \\
\text { bac3 } \\
\end{array}$ & $\begin{array}{r}\text { D10-R7 } \\
\text { bac4 } \\
\end{array}$ & $\begin{array}{r}\text { D03-B1 } \\
\text { bac1 } \\
\end{array}$ & $\begin{array}{r}\text { D03-B1 } \\
\text { bac2 }\end{array}$ & $\begin{array}{r}\text { D03-B1 } \\
\text { bac3 } \\
\end{array}$ \\
\hline Acidobacteria & 14336 & 11021 & 15071 & 404 & 526 & 311 & 311 & 12687 & 10869 & 11616 \\
\hline Actinobacteria & 4724 & 4340 & 5322 & 562 & 709 & 729 & 757 & 3901 & 3426 & 3410 \\
\hline Bacteroidetes & 616 & 533 & 692 & 964 & 3254 & 2213 & 1946 & 114 & 200 & 153 \\
\hline Calditrichaceae & 43 & 33 & 52 & 633 & 1679 & 1334 & 2057 & 49 & 33 & 32 \\
\hline Chloroflexi & 12335 & 9326 & 15451 & 3407 & 1459 & 1424 & 2142 & 20841 & 21217 & 19102 \\
\hline Dadabacteria & 4008 & 2468 & 4064 & 8 & 3 & 5 & 0 & 2394 & 2287 & 1782 \\
\hline Sulfurovum & 6 & 6 & 2 & 406 & 465 & 268 & 256 & 0 & 0 & 0 \\
\hline Sulfurimonas & 4 & 1 & 0 & 114 & 344 & 267 & 324 & 0 & 0 & 1 \\
\hline $\begin{array}{l}\text { Epsilonproteobacteria } \\
\text { (others) }\end{array}$ & 0 & 1 & 1 & 25 & 58 & 37 & 56 & 0 & 0 & 0 \\
\hline Gemmatimonadetes & 1549 & 1113 & 1780 & 7 & 0 & 3 & 2 & 1256 & 1039 & 1042 \\
\hline Nitrospinae & 151 & 127 & 202 & 1 & 0 & 0 & 0 & 217 & 175 & 186 \\
\hline Nitrospira & 2920 & 1912 & 3287 & 1 & 7 & 8 & 6 & 466 & 365 & 374 \\
\hline
\end{tabular}


Table S1: Continued

\begin{tabular}{|c|c|c|c|c|c|c|c|c|c|c|}
\hline Taxonomy & $\begin{array}{r}\text { D10-R3 } \\
\text { _bac1 } \\
\end{array}$ & $\begin{array}{r}\text { D10-R3 } \\
\text { bac2 } \\
\end{array}$ & $\begin{array}{r}\text { D10-R3 } \\
\text { bac3 } \\
\end{array}$ & $\begin{array}{r}\text { D10-R7 } \\
\text { bac1 } \\
\end{array}$ & $\begin{array}{r}\text { D10-R7 } \\
\text { _bac2 } \\
\end{array}$ & $\begin{array}{r}\text { D10-R7 } \\
\text { _bac3 } \\
\end{array}$ & $\begin{array}{r}\text { D10-R7 } \\
\text { _bac4 } \\
\end{array}$ & $\begin{array}{r}\text { D03-B1 } \\
\text { bac1 } \\
\end{array}$ & $\begin{array}{r}\text { D03-B1 } \\
\text { bac2 } \\
\end{array}$ & $\begin{array}{r}\text { D03-B1 } \\
\text { _bac3 } \\
\end{array}$ \\
\hline Kaiserbacteria & 847 & 465 & 1068 & 2 & 2 & 26 & 9 & 118 & 74 & 122 \\
\hline Planctomycetes & 297 & 242 & 390 & 1132 & 1585 & 1540 & 1344 & 159 & 170 & 129 \\
\hline Poribacteria & 464 & 332 & 637 & 31 & 8 & 6 & 12 & 592 & 483 & 510 \\
\hline Alphaproteobacteria & 2194 & 1609 & 2999 & 54 & 317 & 382 & 165 & 2593 & 2244 & 2315 \\
\hline Desulfatiglans & 2 & 0 & 0 & 895 & 1047 & 558 & 782 & 0 & 0 & 0 \\
\hline Desulfococcus & 0 & 0 & 0 & 1984 & 1878 & 590 & 1380 & 0 & 0 & 0 \\
\hline SEEP-SRB1 & 5 & 1 & 3 & 2238 & 1536 & 1352 & 1085 & 0 & 0 & 0 \\
\hline Desulfobulbus & 3 & 0 & 0 & 355 & 375 & 367 & 685 & 0 & 0 & 0 \\
\hline SEEP-SRB2 & 0 & 0 & 0 & 1199 & 1223 & 1162 & 1255 & 0 & 0 & 0 \\
\hline Myxococcales & 498 & 381 & 750 & 74 & 73 & 77 & 105 & 1509 & 1129 & 1428 \\
\hline $\begin{array}{l}\text { Deltaproteobacteria } \\
\text { (others) }\end{array}$ & 259 & 168 & 312 & 3204 & 2854 & 2174 & 2360 & 266 & 245 & 256 \\
\hline Sedimenticolaceae & 0 & 1 & 0 & 136 & 216 & 357 & 324 & 0 & 0 & 0 \\
\hline Thiohalophilus & 0 & 0 & 1 & 93 & 172 & 99 & 113 & 0 & 0 & 0 \\
\hline
\end{tabular}


Table S1: Continued.

\begin{tabular}{|c|c|c|c|c|c|c|c|c|c|c|}
\hline Taxonomy & $\begin{array}{r}\text { D10-R3 } \\
\text { bac1 } \\
\end{array}$ & $\begin{array}{r}\text { D10-R3 } \\
\text { bac2 }\end{array}$ & $\begin{array}{r}\text { D10-R3 } \\
\text { bac3 }\end{array}$ & $\begin{array}{r}\text { D10-R7 } \\
\text { bac1 } \\
\end{array}$ & $\begin{array}{r}\text { D10-R7 } \\
\text { bac2 } \\
\end{array}$ & $\begin{array}{r}\text { D10-R7 } \\
\text { _bac3 } \\
\end{array}$ & $\begin{array}{r}\text { D10-R7 } \\
\text { _bac4 } \\
\end{array}$ & $\begin{array}{r}\text { D03-B1 } \\
\text { bac1 } \\
\end{array}$ & $\begin{array}{r}\text { D03-B1 } \\
\text { bac2 } \\
\end{array}$ & $\begin{array}{r}\text { D03-B1 } \\
\text { bac3 } \\
\end{array}$ \\
\hline Enterobacteria & 28 & 13 & 44 & 1 & 0 & 0 & 0 & 847 & 1829 & 1357 \\
\hline MMG-2 & 1 & 4 & 4 & 66 & 462 & 679 & 422 & 0 & 0 & 0 \\
\hline Nitrosococcaceae & 397 & 271 & 597 & 0 & 0 & 1 & 1 & 2442 & 1907 & 2043 \\
\hline Woeseiaceae & 395 & 307 & 556 & 14 & 52 & 118 & 50 & 2025 & 2086 & 1856 \\
\hline $\begin{array}{l}\text { Thiomicrospiraceae } \\
\text { (endosymbionts) }\end{array}$ & 0 & 1 & 0 & 392 & 639 & 534 & 712 & 0 & 0 & 0 \\
\hline Thiotrichaceae & 0 & 0 & 2 & 185 & 498 & 671 & 506 & 0 & 0 & 0 \\
\hline $\begin{array}{l}\text { Gammaproteobacteria } \\
\text { (others) }\end{array}$ & 4127 & 2572 & 4572 & 138 & 850 & 908 & 571 & 2103 & 1992 & 1980 \\
\hline Spirochaeta & 853 & 541 & 1021 & 344 & 442 & 410 & 256 & 293 & 254 & 301 \\
\hline Verrucomicrobia & 392 & 254 & 505 & 0 & 1 & 0 & 0 & 1037 & 1207 & 1080 \\
\hline Unclassified & 392 & 304 & 612 & 1857 & 2548 & 1680 & 1911 & 253 & 267 & 295 \\
\hline
\end{tabular}


Table S2: Number of reads related to different archaeal taxa found in the analyzed samples.

\begin{tabular}{|c|c|c|c|c|c|c|c|c|c|c|}
\hline Taxonomy & $\begin{array}{r}\text { D10-R3 } \\
\text { arch1 } \\
\end{array}$ & $\begin{array}{r}\text { D10-R3 } \\
\operatorname{arch} 2 \\
\end{array}$ & $\begin{array}{r}\text { D10-R3 } \\
\text { arch3 } \\
\end{array}$ & $\begin{array}{r}\text { D10-R7 } \\
\text { arch1 } \\
\end{array}$ & $\begin{array}{r}\text { D10-R7 } \\
\text { arch2 } \\
\end{array}$ & $\begin{array}{r}\text { D10-R7 } \\
\text { _arch3 } \\
\end{array}$ & $\begin{array}{r}\text { D10-R7 } \\
\text { arch4 } \\
\end{array}$ & $\begin{array}{r}\text { D03-B1 } \\
\text { arch1 } \\
\end{array}$ & $\begin{array}{r}\text { D03-B1 } \\
\operatorname{arch} 2 \\
\end{array}$ & $\begin{array}{r}\text { D03-B1 } \\
\_\operatorname{arch} 3 \\
\end{array}$ \\
\hline ANME-1 & 2 & 8 & 1 & 18976 & 3699 & 11170 & 15108 & 0 & 0 & 0 \\
\hline ANME-2 & 304 & 254 & 119 & 17049 & 9842 & 14581 & 14865 & 1 & 1 & 0 \\
\hline Thermoplasmata & 0 & 1 & 1 & 219 & 83 & 380 & 137 & 3 & 1 & 0 \\
\hline $\begin{array}{l}\text { Candidatus } \\
\text { Nitrosopumilus }\end{array}$ & 5841 & 6724 & 6074 & 3 & 1 & 1 & 1 & 2286 & 3931 & 3726 \\
\hline Cenarchaeum & 28772 & 30241 & 28018 & 0 & 0 & 0 & 0 & 30843 & 38709 & 38587 \\
\hline Nitrosophaera (others) & 2197 & 2625 & 2728 & 7 & 0 & 2 & 0 & 106 & 165 & 149 \\
\hline Asgardaeota & 0 & 1 & 0 & 475 & 156 & 493 & 450 & 2 & 0 & 0 \\
\hline Bathyarchaeia & 0 & 0 & 0 & 25 & 24 & 104 & 52 & 0 & 1 & 0 \\
\hline Woesearchaeia & 1475 & 3941 & 1015 & 35 & 8 & 20 & 30 & 13 & 17 & 10 \\
\hline Unclassified & 1477 & 3943 & 1017 & 823 & 282 & 1050 & 788 & 15 & 18 & 10 \\
\hline
\end{tabular}




\title{
3 Small Siboglinidae worms under scrutiny - including their tube as a part of their microbiota
}

Blanca Rincón-Tomás ${ }^{1}$, Luis Somoza ${ }^{4}$, Javier González ${ }^{4}$, Teresa Medialdea ${ }^{4}$, Kathrin Sauter ${ }^{1}$, Dorothea Hause-Reitner ${ }^{2}$, Pedro Madureira ${ }^{5}$, Jens Carlsson ${ }^{6}$, Joachim Reitner $^{2,3}$, Michael Hoppert ${ }^{1}$

${ }^{1}$ Georg-August-University Göttingen, Institute of Microbiology and Genetics, Grisebachstraße 8, 37077 Göttingen, Germany

${ }^{2}$ Georg-August-University Göttingen, Göttingen Centre of Geosciences, Goldschmidtstraße 3, 37077 Göttingen, Germany

${ }^{3}$ Göttingen Academy of Sciences and Humanities, Theaterstraße 7, 37073 Göttingen, Germany

${ }^{4}$ Marine Geology Dv., Geological Survey of Spain, IGME, Ríos Rosas 23, 28003 Madrid, Spain

${ }^{5}$ Estrutura de Missão para a Extensão da Plataforma Continental. Rua Costa Pinto 165, 2770-047 Paço de Arcos, Portugal

${ }^{6}$ Area 52 Research Group, School of Biology and Environmental Science/Earth Institute, University College Dublin, Belfield, Dublin 4, Republic of Ireland

Corresponding Author:

Blanca Rincón-Tomás ${ }^{1}$

Email address: b.rincontomas@gmail.com

\begin{abstract}
Siboglinid worms were sampled from four mud volcanoes in the Gulf of Cádiz (El Cid MV, Bonjardim MV, Al Gacel MV and Anastasya MV). These invertebrates are characteristic to cold seeps and are known to host chemosynthetic endosymbionts in a dedicated trophosome organ. However, little is known about their tube as a potential niche for other chemosynthetic and non-chemosynthetic microorganisms. Analyses by scanning and transmission electron microscopy show
\end{abstract}


dense biofilms on the tube in $\mathrm{Al}$ Gacel MV and Anastasya MV specimens by prokaryotic cells. Methanotrophic bacteria are the most abundant forming these biofilms as further confirmed with $16 \mathrm{~S}$ rDNA sequence analysis. Furthermore, elemental analyses with electron microscopy and EDX point to the progressive mineralization of the biofilm and the tube in absence of nutrients. Environmental bacterial and archaeal $16 \mathrm{~S}$ rDNA sequence libraries revealed abundant microorganisms related to these worms and variation in microbial communities among samples. We argue that these differences must be related to variance in seepage activity, as it is the source of nutrients. Thus, the tube needs to be incorporated as an important part of the worm's microbiota, and empty tubes may still influence the composition of the active microbial community of the sediment surface.

\subsection{Introduction}

Chemosynthetic fauna is widely distributed and often found in deep-sea areas of active fluid seepage where oxygen levels are normally low, such as hydrothermal vents and cold seeps. However, they can also be found in other reduced environments, such as whale and wood falls (Stewart et al., 2005; Dubilier et al., 2008; Lösekann et al., 2008; Roeselers \& Newton. 2012; Levin et al., 2016). While the composition of the seepage fluids is variable, some bacteria and archaea have adapted to use some of the most abundant constituents as their energy and/or carbon source, i.e. methane and sulfur compounds. These chemosynthetic microorganisms produce organic compounds and act as primary producers supporting higher trophic levels at these habitats (Jannasch \& Mottl, 1985; Jannasch, 1989).

Characteristic fauna found in these ecosystems include bivalves (within the Mytilidae, Vesicomyidae, Solemyidae, Thyasiridae and Lucinidae families; Duperron et al., 2007; 2013; Roeselers \& Newton, 2012; Raggi et al., 2013), tubeworms (within the Alvinellidae and Siboglinidae families; Lösekann et al., 2008; Raggi et al., 2013; Georgieva et al., 2015), and protozoan like ciliates (Ott et al., 2004; Edgcomb et al., 2011), that are symbiotic with these chemolitoautotrophic bacteria. These bacteria 
provide their hosts with rich source of nutrients in a high methane and sulfur environment where they are protected inside the hosts.

Tube fossils of siboglinid worms from vent sites are dated from the Silurian period, ca. 430 Ma ago (Little et al., 1998; Hilário et al., 2011; Georgieva et al., 2015). Taxonomic groups of the Siboglinidae family are described as a fundamental part of the core chemosynthetic community in reduced environments (Hilário et al., 2011). Siboglinids are normally found in the oxic/anoxic interface, as the symbiotic microorganisms requires oxygen as the electron acceptor to oxidize methane or sulfide. For instance, seep siboglinids are normally found with the anterior part of their chitin tube (Blackwell et al., 1965) in contact with the water column, from where they acquire the oxygen, while the posterior part is inside the reduced sediment, from where they collect the nutrients for their endosymbionts (Dubilier et al., 2008).

Adult siboglinids lack gut and rely on their endosymbiotic bacteria for nutrition, which are located in bacteriocytes inside the highly vascularized trophosome organ (Bright \& Giere, 2005; Southward et al., 2005). Thiotrophic Gammaproteobacteria are the most common microorganisms found in siboglinid trophosomes (Petersen \& Dubilier, 2009). However, methanotrophic symbionts in siboglinid species from methane vents have also been reported, i.e. Siboglinum poseidoni (Schmaljohann \& Flügel, 1987; Rodrigues et al., 2013) and Sclerolinum contortum (Pimenov et al., 2000). To date, all methanotrophic symbionts identified are related to type I methanotrophs from the Gammaproteobacteria, while type II methanotrophs from the Alphaproteobacteria have not been found as symbionts in any marine invertebrate (Petersen \& Dubilier, 2009).

While most studies are focused on the interaction between siboglinids and their endosymbionts, few studies have reported the presence of microorganisms colonizing the tube or considered the tube as potential niches for other chemosynthetic and nonchemosynthetic microorganisms. Not only microbial communities have been described on the outside of the tubes of Riftia pachyptila (López-García et al., 2002), Lamellibrachia sp. (Duperron et al., 2009), but bacteria have also been found in the internal face of the tube (Duperron et al., 2009). Furthermore, Georgieva et al. (2015) 
found bacterial biofilms inside the tube of Alvinella sp. worms (Alvinellidae family), acting as one more concentric layer of the multiple layers that constitute the tube of the worms. These extraneous microbial inner cores were proposed to be formed due to the colonization of the surface of the tube followed by its normal progressive mineralization.

In the present study, we elucidate the tube of siboglinid worms as a potential niche for microorganisms. This implies an increase in the microbiota of the worms as well as in the total microbial biomass of cold seep ecosystems. For this purpose, we examined different specimens of small siboglinids recovered from four mud volcanoes in the Gulf of Cadiz, i. e. El Cid MV, Bonjardim MV, Al Gacel MV and Anastasya MV. We used transmission electron microscopy (TEM) and scanning electron microscopy (SEM) for the characterization of the tube and tissue of these worms, as well as Illumina next generation sequencing for the amplification of environmental 16s rDNA of the prokaryotes present in the specimens. Based on our findings, we attempt to characterize the endosymbionts of the sampled specimens, as well as to characterize the diversity of microbiota of the worms. Moreover, we consider the importance of the tube as a part of the total biomass of the siboglinids microbiota, and how this microbial community may vary depending on the availability of nutrients.

\subsection{Experimental Procedures}

\subsubsection{Specimen collection}

To study the microbiota of small siboglinid worms, specimens were recovered from different mud volcanoes in the Gulf of Cadiz. El Cid MV, Bonjardim MV and Al Gacel MV were sampled during the YEAR Subvent-2 cruise (R/V Sarmiento de Gamboa), while the Anastasya MV was sampled during the 2015 Deep-Links cruise (R/V Celtic Explorer) (Fig. 1). From each mud volcano a group of worms (between 10 and 15) were fixed for transmission and scanning electron microscopy (TEM \& SEM, respectively) and some stored in ethanol or kept at $-80{ }^{\circ} \mathrm{C}$ for DNA analysis. 


\subsubsection{Transmission electron microscopy (TEM)}

Specimens from Al Galcel MV and Anastasya MV were fixed in 2.5\% (w/v) glutaraldehyde. After washing several times with phosphate-buffered saline (137 mM $\mathrm{NaCl}, 2.7 \mathrm{mM} \mathrm{KCl}, 10 \mathrm{mM} \mathrm{Na} 2 \mathrm{HPO}_{4}, 1.8 \mathrm{mM} \mathrm{KH}_{2} \mathrm{PO}_{4}, \mathrm{pH}$ 7.4), a dehydration series was performed $(15 \%, 30 \%, 50 \%, 70 \%, 95 \%$ and $100 \%$ aqueous ethanol solution), followed by embedding the samples with Medium LR white resin (Plano, Wetzlar, Germany). Polymerization of the resin was at $60{ }^{\circ} \mathrm{C}$ during $24 \mathrm{~h}$. A milling tool (TM 60, Fa. Reichert and Jung, Vienna, Austria) was used to make a truncated pyramid on the gelatin capsules. Furthermore, an ultramicrotome (Ultracut E, Reichert \& Jung, Vienna, Austria) and glass knives were used for obtaining ultrathin sections of the sample. Ultrathin sections were $80 \mathrm{~nm}$ in thickness, mounted on 300 mesh specimen Grids (Plano) and further stained with 4\% (w/v) uranyl acetate (positive stain). The sections were inspected in a Jeol EM 1011 transmission electron microscope (Jeol, Eching, Germany).

\subsubsection{Scanning electron microscopy (SEM) and energy-dispersive X-ray spectroscopy (EDX) analysis}

Specimens from El Cid MV, Al Gacel MV and Anastasya MV were fixed in $2.5 \%$ (w/v) glutaraldehyde. After washing several times with phosphate-buffered saline, a dehydration series was performed $(15 \%, 30 \%, 50 \%, 70,80 \%, 90 \%, 95 \%$ and $100 \%$ aqueous solution), followed by hexamethyldisilazane (HMDS; Sigma-Aldrich, Germany) in order to avoid drying artefacts (Brown, 1993). Samples were mounted on SEM sample holders and sputtered with $\mathrm{Au}-\mathrm{Pd}(13.9 \mathrm{~nm}$ for $120 \mathrm{~s})$. They were further visualized in a SEM LEO 1530 Gemini (Zeiss, Oberkochen, Germany) combined with an INCA X-ACT EDX.

\subsubsection{Fluorescent staining of chitin tubes}

Specimens recovered from the Al Gacel MV were stained with calcofluor white (Sigma-Aldrich, Germany) to identify the chitin tube. Previous staining of the samples, they were fixed on a slide and embedded in paraffin followed by a graded ethanol 
series $(100 \%, 90 \%, 70 \%$ and 50\%). Afterwards, one drop of staining and one drop of $\mathrm{KOH} 10 \%$ were placed onto the slide with the sample. The samples were examined under UV filters with different excitation ranges (i. e. $365 \mathrm{~nm}, 395-440 \mathrm{~nm}$ and 450 - $490 \mathrm{~nm}$ ) of a Zeiss Axioplan microscope (Oberkochen, Germany).

\subsubsection{DNA extraction and amplification of bacterial and archaeal 16S rRNA genes}

Specimens from El Cid MV, Bonjardim MV, Al Gacel MV and Anastasya MV were used for this analysis. About $1 \mathrm{~g}$ of sample was first mashed with mortar and liquid nitrogen to fine powder. Total DNA was isolated with Power Soil DNA Extraction Kit (MO BIO Laboratories, Carlsbad, CA) according to the manufacturer's instructions. Bacterial amplicons of the V3 - V4 region were generated with the primer set MiSeq_Bacteria_V3_forward primer TCGTCGGCAGCGTCAGATGTGTATAAGAGACAGCCTACGGGNGGCWGCA G-3') and MiSeq_Bacteria_V4_reverse primer (5'GTCTCGTGGGCTCGGAGATGTGTATAAGAGACAGGACTACHVGGGTATC TAATCC-3'). Likewise, archaeal amplicons of the V3 - V4 region were generated with the primer set MiSeq_Archaea_V3_forward primer (5'TCGTCGGCAGCGTCAGATGTGTATAAGAGACAG-

GGTGBCAGCCGCCGCGGTAA-3') and MiSeq_Archaea_V4_reverse primer (5'GTCTCGTGGGCTCGGAGATGTGTATAAGAGACAG-

CCCGCCAATTYCTTTAAG-3'). The PCR reaction mixture for bacterial DNA amplification, with a total volume of $50 \mu \mathrm{l}$, contained $1 \mathrm{U}$ Phusion high fidelity DNA polymerase (Biozym Scientific, Oldendorf, Germany), 5\% DMSO, $0.2 \mathrm{mM}$ of each primer, $200 \mu \mathrm{M}$ dNTP, $0.15 \mu \mathrm{l}$ of $25 \mathrm{mM} \mathrm{MgCl}_{2}$, and $25 \mathrm{ng}$ of isolated DNA. Furthermore, PCR protocol for bacterial DNA amplification was: initial denaturation for $1 \mathrm{~min}$ at $98^{\circ} \mathrm{C}, 25$ cycles of $45 \mathrm{~s}$ at $98{ }^{\circ} \mathrm{C}, 45 \mathrm{~s}$ at $60^{\circ} \mathrm{C}$, and $30 \mathrm{~s}$ at $72{ }^{\circ} \mathrm{C}$, and a final extension at $72{ }^{\circ} \mathrm{C}$ for $5 \mathrm{~min}$.

The PCR reaction mixture for archaeal DNA amplification was similarly prepared but containing $1 \mu \mathrm{l}$ of $25 \mathrm{mM} \mathrm{MgCl} 2$ and $50 \mathrm{ng}$ of isolated DNA. PCR protocol for archaeal DNA amplification was: initial denaturation for $1 \mathrm{~min}$ at $98^{\circ} \mathrm{C}, 10$ cycles of 
$45 \mathrm{~s}$ at $98{ }^{\circ} \mathrm{C}, 45 \mathrm{~s}$ at $63{ }^{\circ} \mathrm{C}$, and $30 \mathrm{~s}$ at $72{ }^{\circ} \mathrm{C}, 15$ cycles of $45 \mathrm{~s}$ at $98{ }^{\circ} \mathrm{C}, 45 \mathrm{~s}$ at $53{ }^{\circ} \mathrm{C}$, and $30 \mathrm{~s}$ at $72{ }^{\circ} \mathrm{C}$, and a final extension at $72{ }^{\circ} \mathrm{C}$ for $5 \mathrm{~min}$. PCR products were then checked by agarose gel electrophoresis (1.3\% agarose, 100 bp ladder) and purified using the GeneRead Size Selection Kit (QIAGEN GmbH, Hilden, Germany).

\subsubsection{MiSeq Illumina processing pipeline}

Illumina 300PE sequencing of the amplicons and further process of the sequence data were performed in the Göttingen Genomics Laboratory (Göttingen, Germany). After Illumina MiSeq processing, sequences were analyzed. Paired-end sequences were merged using PANDAseq (Masella et al., 2012). PANDAseq uses the algorithm PEAR (Zhang et al., 2013) for the assembly. Sequences containing unresolved bases and reads shorter than 305 bp were removed (Masella et al., 2012). Non-clipped reverse and forward primer sequences were removed by employing cutadapt 1.15 (Martin, 2011). USEARCH version 9.2.64 was used with the QIIME pipeline (Caporaso, 2010). The sequences were dereplicated, and denoised also with the QIIME using USEARCH resulting in amplicon sequence variants (ASVs). The taxonomic classification of the assigned sequences was performed with QIIME 1.9.1 against the SILVA database 132 with the assignment method mothur (Yilmaz et al., 2014). Extrinsic domain ASVs, chloroplasts, and unclassified ASVs were removed from the dataset. Sample comparisons were performed at same study, utilizing the lowest number of sequences by random subsampling (20,290 reads for bacteria, 13,900 reads for archaea).

\subsection{Results}

\subsubsection{Samples and in situ variables' measurement}

Worm samples were recovered from different mud volcanoes at sites where reduced sediment was observed. Exact location of the samples, as well as physical and chemical measured variables at those sites were collected from the remoted operated vehicle (ROV) sensors ( $\mathrm{CH}_{4}$ and $\left.\mathrm{CTD}\right)$ and are shown in Table 1. El Cid MV and Bonjardim MV specimens were sampled from grey mounds (Fig. 1, B-C). El Cid MV 
sample was taken with a push-core and worms were in the first $5 \mathrm{~cm}$ of sediment. In the case of the Bonjardim MV sample, the sediment was recovered with suction sampler and emanated a strong hydrogen sulfide smell. Siboglinids recovered from the Al Gacel MV were located in a pockmark, beneath an AOM-derived carbonate and facing an active bubbling seepage (Fig. 1, D; Rincón-Tomás et al., 2018). Furthermore, Anastasya MV worms were obtained from a field of Beggiatoa-like biofilms (Fig. 1, E). All specimens were around $100 \mu \mathrm{m}$ width and no longer than $15 \mathrm{~cm}$. They had a light-brownish color due to their tubes. No morphological identification of the worms could be made, presuming they are Siboglinum sp. or Sclerolinum sp. worms due to their size and external appearance. 
Table 1: Exact sampling sites and variables' measurement obtained from $\mathrm{CH}_{4}$ and $\mathrm{CTD}$ sensors of the ROV

\begin{tabular}{|c|c|c|c|c|c|c|c|c|}
\hline $\begin{array}{l}\text { Mud } \\
\text { Volcano }\end{array}$ & Coordinates & $\begin{array}{l}\text { Depth } \\
\text { (m) }\end{array}$ & $\begin{array}{l}\text { Temp. } \\
\left({ }^{\circ} \mathbf{C}\right)\end{array}$ & $\begin{array}{l}\mathrm{O}_{2} \\
(\%)\end{array}$ & $\mathrm{CH}_{4}$ & pH & $\begin{array}{l}\text { ORP } \\
(\mathrm{mV})\end{array}$ & Description \\
\hline El Cid & $\begin{array}{l}35^{\circ} 26.32^{\prime} \mathrm{N} \\
-7^{\circ} 29.03 \mathrm{~W}\end{array}$ & 1229 & 9.6 & 57 & Yes & 7.86 & 214 & $\begin{array}{l}\text { grey mound } \\
\text { surrounded by } \\
\text { non- } \\
\text { chemosynthetic } \\
\text { fauna }\end{array}$ \\
\hline Bonjardim & $\begin{array}{l}35^{\circ} 27.52^{\prime} \mathrm{N} \\
-8^{\circ} 59.99^{\prime} \mathrm{W}\end{array}$ & 3051 & 2.8 & 6.14 & Yes & 7.91 & 188 & $\begin{array}{l}\text { mud breccia with } \\
\text { strong sulfidic } \\
\text { smell and shells of } \\
\text { dead bivalves }\end{array}$ \\
\hline Al Gacel & $\begin{array}{l}35^{\circ} 26.47^{\prime} \mathrm{N} \\
-6^{\circ} 58.27 \mathrm{~W}\end{array}$ & 791 & 10 & 54 & Yes & 7.88 & 149 & $\begin{array}{l}\text { bottom of AOM } \\
\text { authigenic } \\
\text { carbonate from } \\
\text { pockmark with } \\
\text { active bubbling }\end{array}$ \\
\hline Anastasya & $\begin{array}{l}36^{\circ} 31.32^{\prime} \mathrm{N} \\
-7^{\circ} 9.02 \mathrm{~W}\end{array}$ & 461 & - & - & Yes & - & - & $\begin{array}{l}\text { black mud } \\
\text { underneath white } \\
\text { sulfur-oxidizing } \\
\text { bacterial mat with } \\
\text { active bubbling }\end{array}$ \\
\hline
\end{tabular}



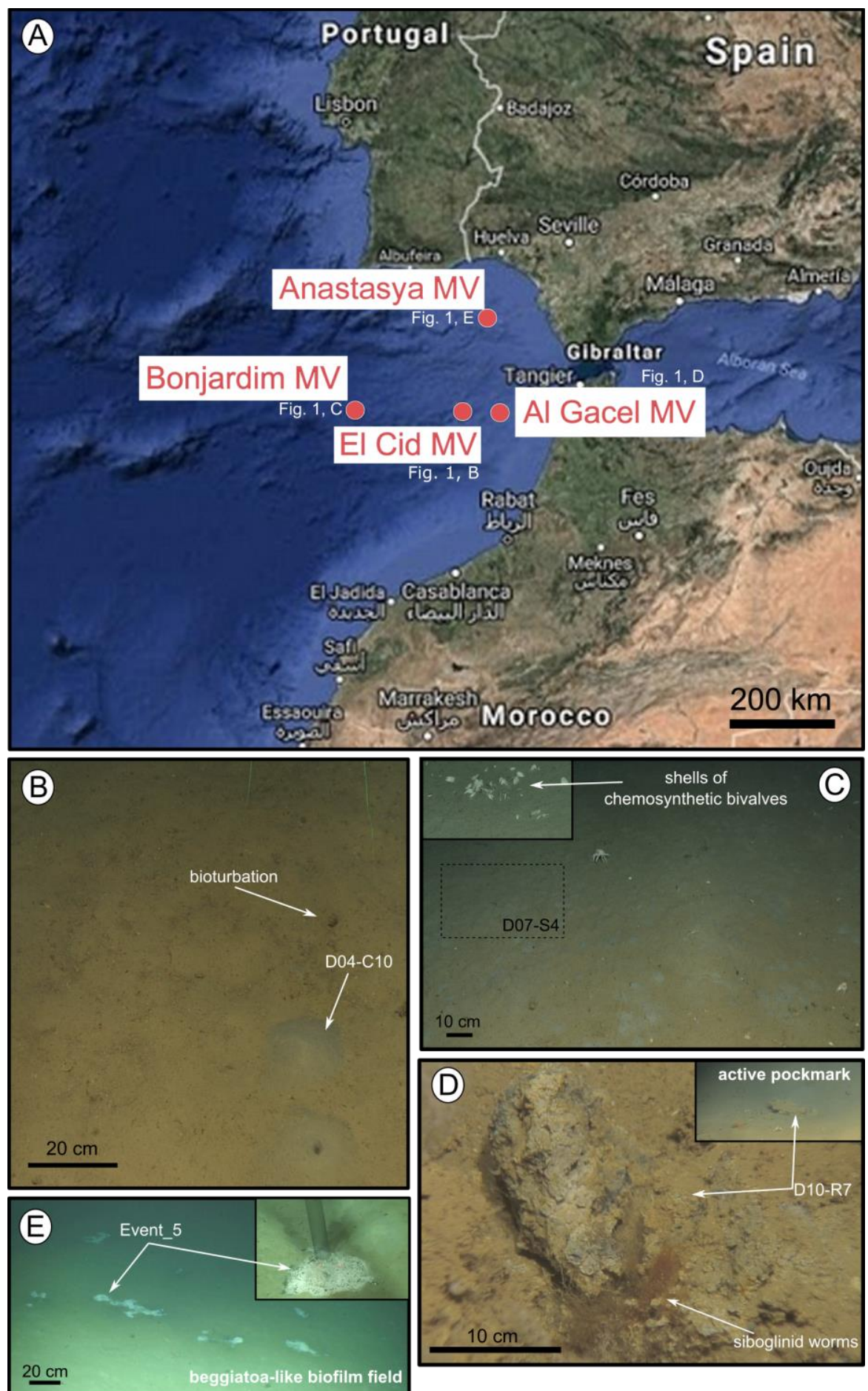

Figure 1: Location of the mud volcanoes sampled for this study in the Gulf of Cádiz and an overview of the sites where samples were recovered. A: General view of the Gulf of Cádiz. The mud volcanoes from where the samples were taken are marked with red points. B-E: ROV still frames from the different sampling sites. B: El Cid MV. C: Bonjardim MV. D: Al Gacel MV. E: Anastasya MV. Exact coordinates in Table 1. 


\subsubsection{Endosymbionts imaging}

Worm tissues were only observed in Al Gacel MV (see supplementary data Figure S1) and Anastasya MV samples (Fig. 2). The other samples were empty tubes. SEM micrographs from one specimen of Anastasya MV revealed the posterior region of the worm (Fig. 2, A) - segmented opisthosoma is observed - and the trophosome (Fig. 2, B). A hole in the trophosome exposed abundant bacteria inside (Fig. 2, C-D). These bacteria were cocci, ca. $0.5 \mu \mathrm{m}$ of diameter and had inner-membranes like the ones expressed by methanotrophic bacteria (Fig. 2, D).
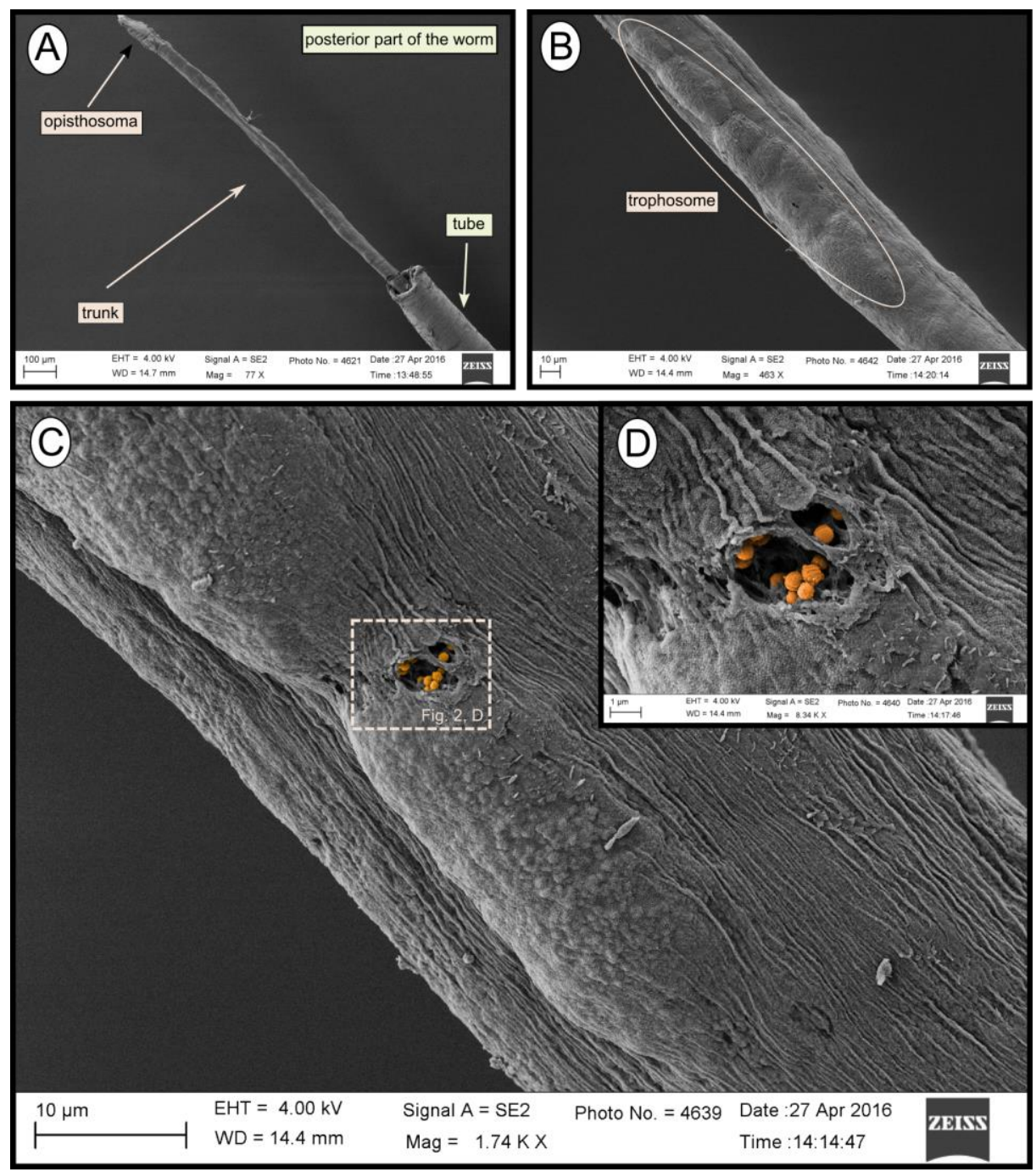

Figure 2: SEM micrographs of one specimen from Anastasya MV. A: general view of the sample. Posterior part of the worm is exposed and outside of the tube. B: trophosome. C-D: closer view to a hole in the trophosome where methanotrophic-like bacteria are observed. 


\subsubsection{Structure and composition of the tubes}

The fluorescent stain calcofluor white is an indicator for polysaccharides such as chitin that is part of the organic matrix of siboglinids' tubes. Sections of empty tubes from the Al Gacel MV expressed high fluorescence when observed under UV-light with different absorption band filters (Fig. 3). Furthermore, an external biofilm de-attached from the tube (probably due to handling of the sample) was slightly fluorescent (Fig. 3, E).
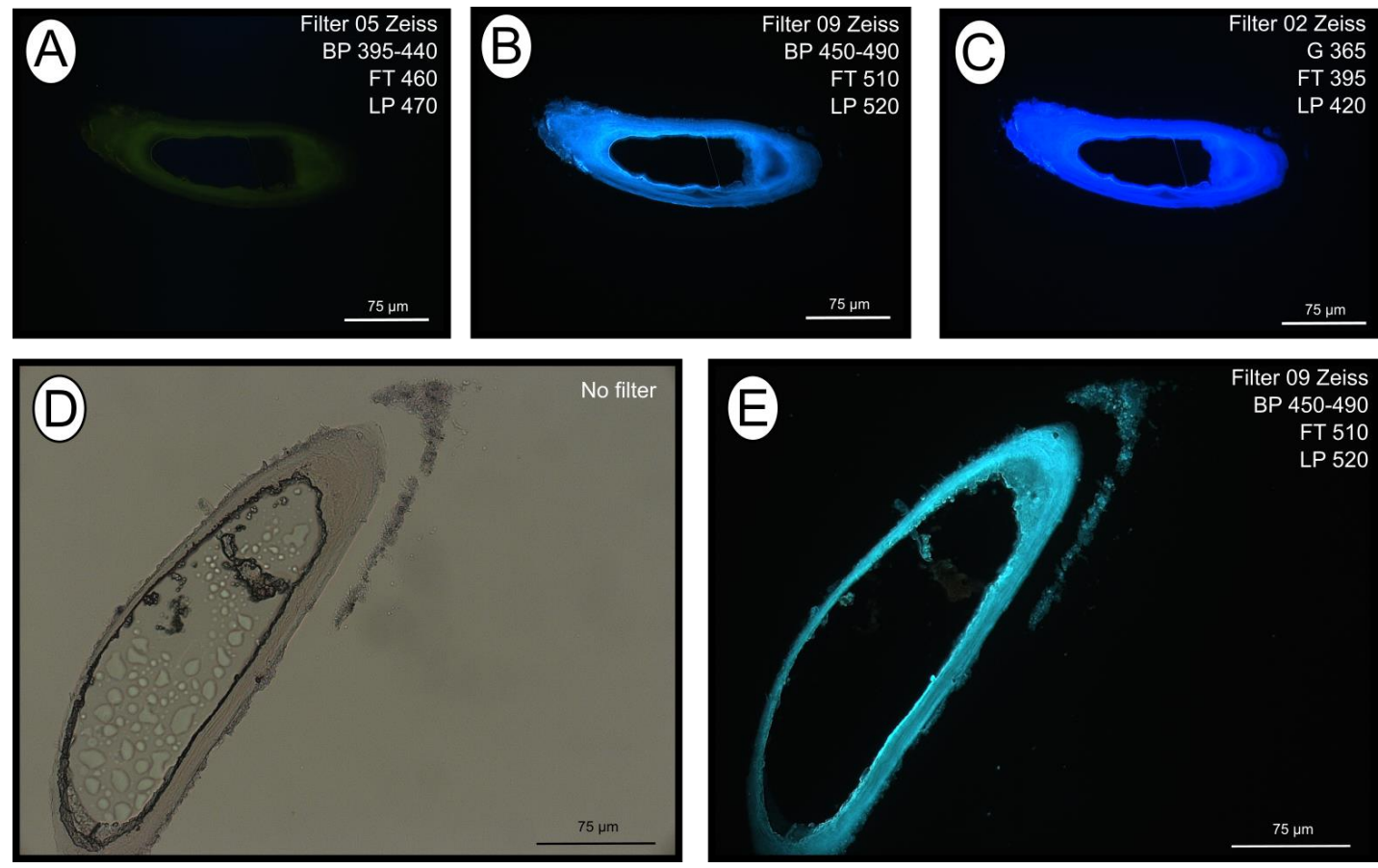

Figure 3: calcofluor white staining of empty tubes recovered from Al Gacel MV. The fluorescence of the tube indicates the presence of chitin. A-C: fluorescence of the same tube section varies between filters. D-E: same section under normal light (D) and using Filter 09 (E). Notice the fluorescence of the tube and the detached biofilm.

SEM micrographs revealed transversal-segmented tubes which were covered by minerals (El Cid MV specimen, Fig. 4, A), a thick biofilm (Al Gacel MV specimen, Fig. 4, B) or putative remains of microbial extracellular polymeric substances or EPS (Anastasya MV specimen, Fig. 4, C). Disrupted tubes revealed their composition of multiple concentric layers $6-10 \mu \mathrm{m}$ of thickness (Fig. 4, D). Some of the layers displayed a filamentous matrix, with attached globular particles of ca. $200 \mathrm{~nm}$ in 
diameter (Fig. 4, E). Layers consisting of these particles, show a silica signal in EDX analysis (see supplementary data Figure S2). Other layers contained significant amounts of iron, sulfur, and calcium, without notable differentiation between them. Detailed interpretation of EDX-analysis is discussed in supplementary data. Furthermore, bacteria were detected in the internal surface of the tube of the Al Gacel MV specimen (Fig. 4, D; Fig. 5, G-H). A model of the different layers observed in a tube in shown in Fig. 4, F. 

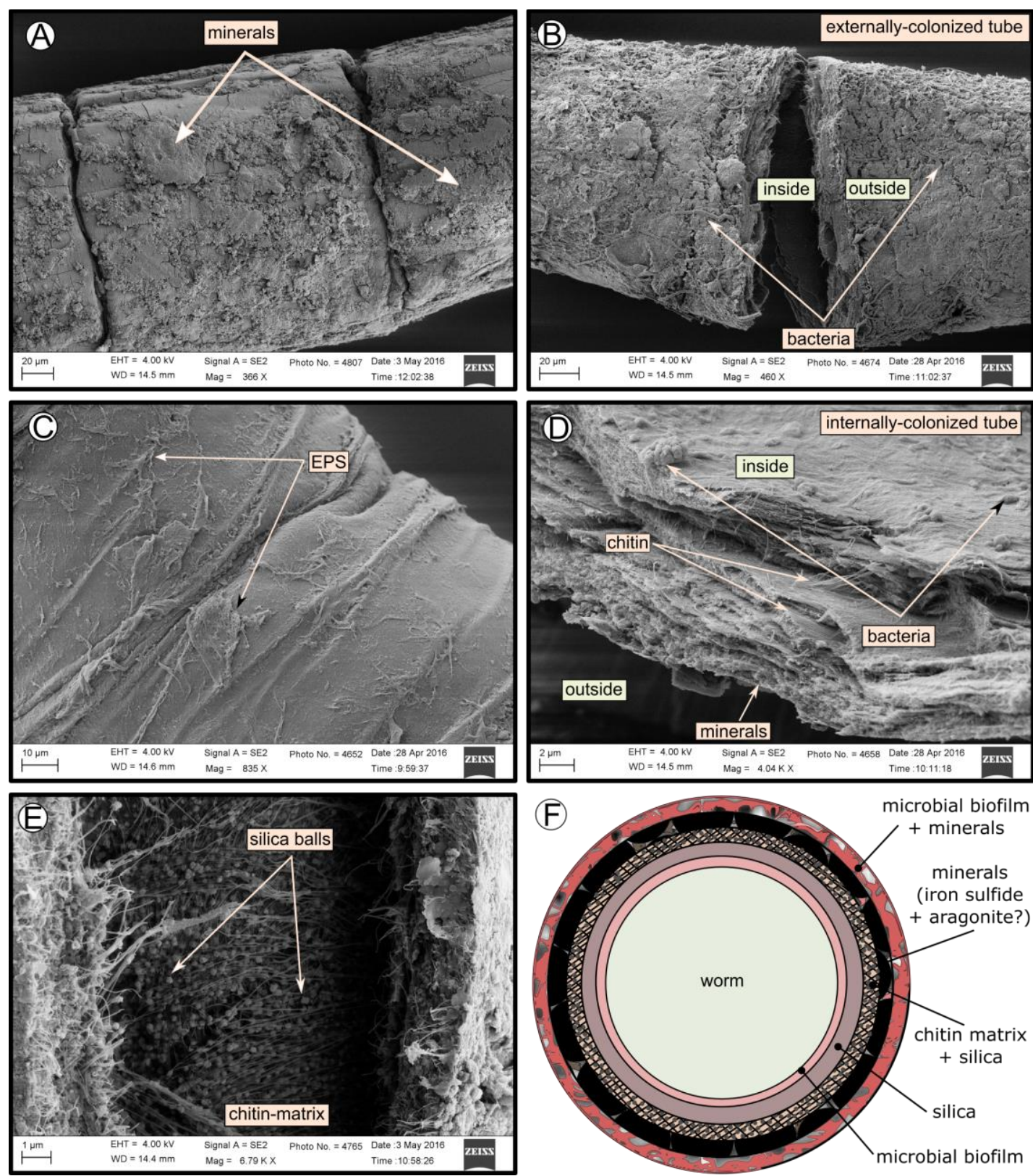

Figure 4: SEM micrographs of the tube of different specimens from different mud volcanoes and the expected display of their layers. A: El Cid MV specimen, with minerals on its external surface. B: Al Gacel MV specimen, with a thick biofilm on its external surface. Microbial colonizers detailed in Fig. 5. C: Anastasya MV specimen with remains of EPS on its external surface. D: Al Gacel MV specimen with bacteria on its internal surface. A multilayer organization of the tube can be observed, chitin layers and minerals can be differentiated. E: internal layer of chitin with rounded silica from El Cid MV specimen. F: model of what is expected to be the arranging of the tube, based on the SEM micrographs, EDX analysis, and references (Peckmann et al., 2005; Haas et al., 2009; Georgieva et al., 2015). 


\subsubsection{Microbial biofilm of the tubes}

TEM and SEM micrographs from the Al Gacel MV revealed a high microbial colonization of the outside surface of the tube (Fig. 4, B; Fig. 5). The biofilm was ca. $1-2 \mu \mathrm{m}$ thick. Bacteria with intracytoplasmic membranes arranged as known for methanotrophic proteobacteria, were the most abundant along the tube, forming densely packed bacteriocyte-like bodies (Fig. 5, A-C). Other microbial morphotypes were observed, i.e. prosthecate, rod shaped, helically shaped and filamentous bacteria (Fig. 5, D-F). Rod-shaped bacteria were also observed attached to the inside surface of the tube (Fig. 5, G-H) Furthermore, some microorganisms appeared to be actively penetrating the chitin tube (Fig. 5, I).

Likewise, siboglinids from Anastasya MV under the TEM revealed a biofilm on the outer tube face. However, the biofilm appeared to be dead and in a degradation process (Fig. 6). Remains of the microbial inner membranes indicate abundance of methanonotrophic-like bacteria, similar to the ones observed in $\mathrm{Al}$ Gacel MV specimens (Fig. 6, A). Remains of bacteria between single layers of the tube were also observed (Fig. 6, B-D). 

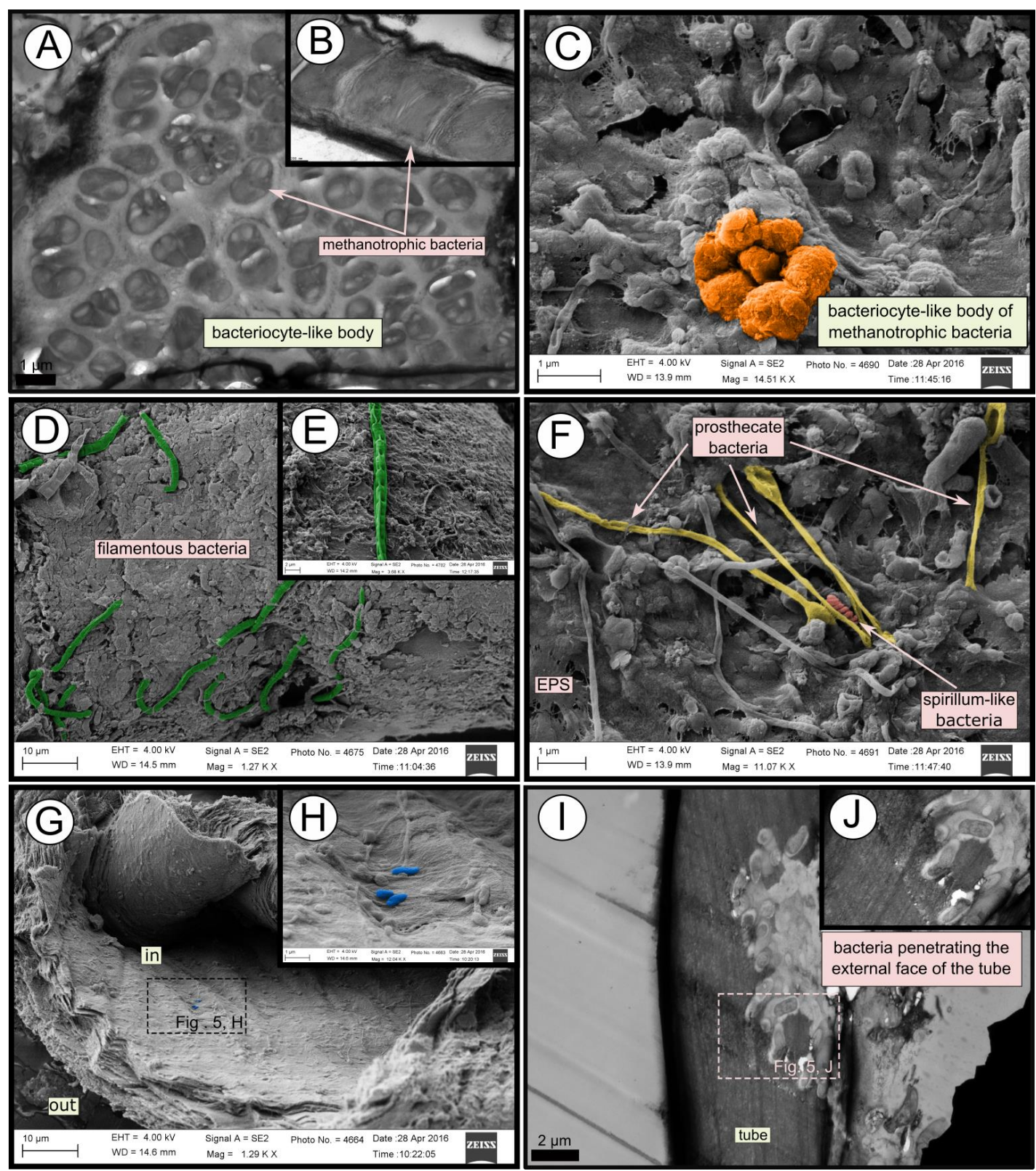

Figure 5: SEM and TEM micrographs of colonized tubes from Al Gacel M. A-C: methanotrophic-like bacteria, organized in bacteriocyte-like bodies and expressing intracytoplasmatic membranes. D-F: different microbial morphotypes observed in the biofilm. G-H: rod-shaped bacteria colonizing the internal surface of the tube. I-J: bacterial biofilm penetrating the tube. 

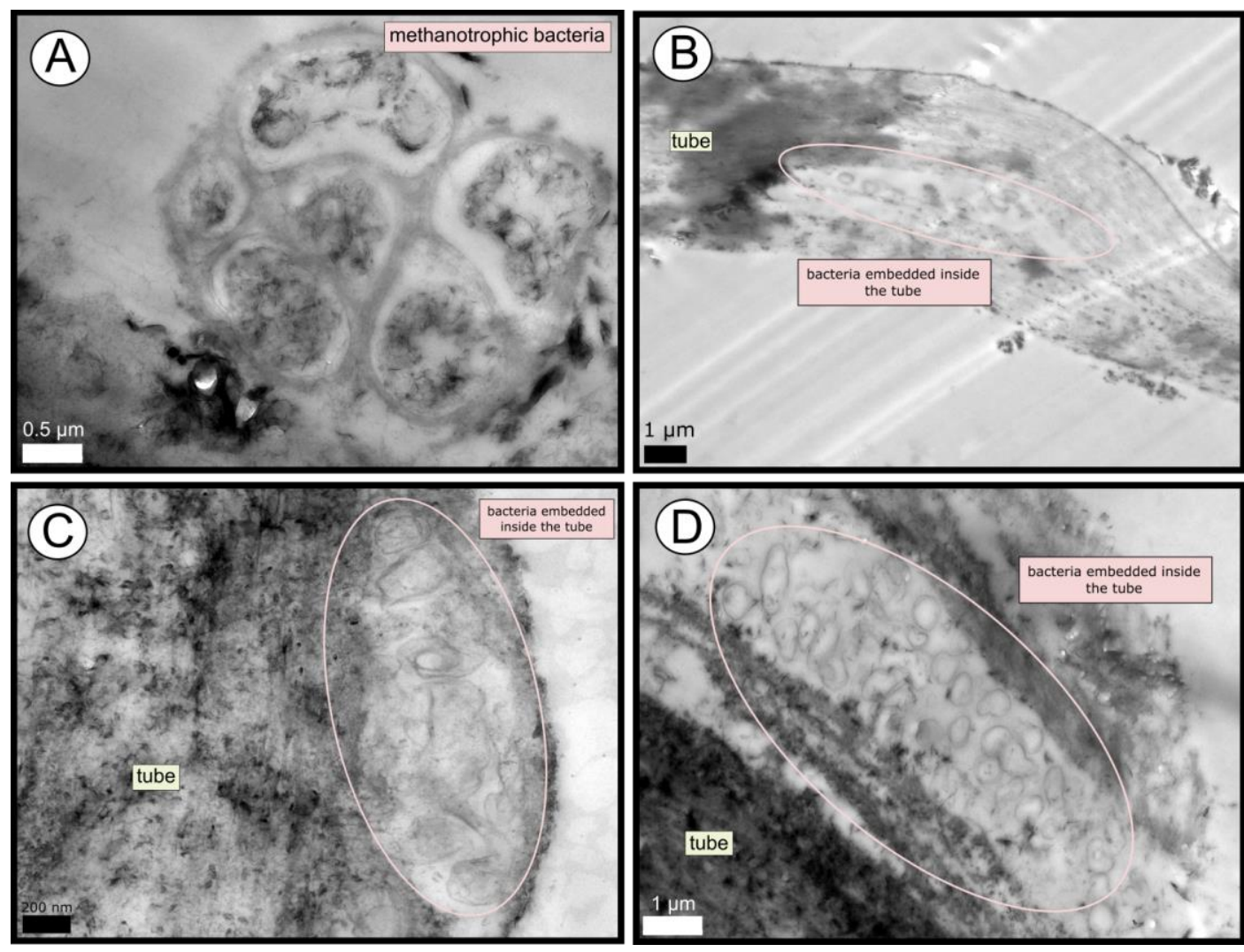

Figure 6: TEM micrographs of remains of a microbial biofilm from tubes of Anastasya MV worms.

Remains of methanotrophic-like bacteria are commonly observed (A). Many bacteria appear to be embedded by the tube (B-D).

\subsubsection{S rDNA library}

Bacterial and archaeal DNA libraries revealed abundance of taxa typically found in deep-sea water and at cold seeps in all the samples, such as Acidobacteria, Actinobacteria, Bateriodetes, Chloroflexi, Thermoplasmata, Woesearchaeota, and Candidatus Nitrosopumilus (Fig. 7, C-D; Tables 2 and 3). They represent metabolisms which role are not well known in these ecosystems. Alpha diversity of the samples is represented in Figure 7, A-B. Bonjardim MV worms present the highest diversity of prokaryotic taxa when compared to the other samples. El Cid MV and Anastasya MV samples are richer in bacterial diversity than in archaeal diversity. On the contrary, $\mathrm{Al}$ Gacel MV worms present a more diverse archaeal community when compare to their bacterial community (Fig. 7, A-B). 
Sulfide-oxidizing bacteria are detected in all samples, being highly representative in El Cid MV sample with up to $40 \%$ relative abundance of bacterial DNA (mostly Thiohalophilus and bacteria from the Thiotrichaceae family; Fig. 7, C; Table 2). Furthermore, Thiotrichaceae family is also the major representation of sulfideoxidizers in Bonjardim MV sample. Sedimenticola endosymbionts, which are sulfideoxidizing bacteria, are representatively abundant in Al Gacel MV specimens, as well as Desulfobacterales sulfate-reducers. Marine Methylotrophic group 2 (MMG-2) methanotrophic bacteria and Desulfobacter sulfate-reducing bacteria are highly abundant in Anastasya MV (Fig. 7, C; Table 2). Additionally, methylotrophic bacteria, such as Hyphomonadaceae (Poindexter, 2006; Ozaki et al., 2007), and Methylotenera (Kalyuzhnaya et al., 2006) taxa are highly abundant in Bonjardim MV and Al Gacel MV samples, respectively (Table 2). Likewise, Chitinivibrionia bacteria are found in all our samples, especially in Anastasya MV worms. These bacteria are chitindegraders. Al Gacel MV and Anastasya MV samples have almost up to $50 \%$ of sequences covered by methane-oxidizing bacteria, sulfide-oxidizing bacteria and sulfate-reducing bacteria (Fig. 7, C).

Archaeal DNA analysis revealed much lower number of sequences in El Cid MV sample when compared to the other samples. Woeserarchaeota (DHVEG-6) are the most abundant archaea in all samples, followed by methane-oxidizing archaea (ANME-1 and ANME-2) as the second most abundant taxa (Fig. 7, D; Table 3). Woesearchaeota are normally found at hydrothermal vents and cold seeps, while ANME archaea are known to participate in the anaerobic oxidations of methane (AOM) together with sulfate-reducing bacteria (Boetius, 2000). Taxa of ANME archaea are oddly distributed between samples. ANME-1a is more abundant in Al Gacel MV sample, while ANME-1b are abundant in El Cid and Bonjardim MV samples. Likewise, ANME-2a-2b are relative abundant in all samples except in Bonjardim MV, which has instead ANME-2c (Table 3). The number of sequence-reads related to methanogenic archaea were homogeneous among the samples, except in the Al Gacel MV where they were almost absent (Table 3). 
Table 2: Number of reads related to different bacterial taxa found in the analyzed samples. The group "others" consist on unclassified OTUs and OTUs which represent less than $1.5 \%$ of total relative abundance in the sample.

\begin{tabular}{|c|c|c|c|c|c|}
\hline & Taxonomy & $\begin{array}{ll}\text { El } & \text { Cid } \\
\text { MV } & \end{array}$ & $\begin{array}{l}\text { Bonjardim } \\
\text { MV }\end{array}$ & $\begin{array}{l}\text { Al Gacel } \\
\text { MV }\end{array}$ & $\begin{array}{l}\text { Anastasya } \\
\text { MV }\end{array}$ \\
\hline \multirow{29}{*}{ 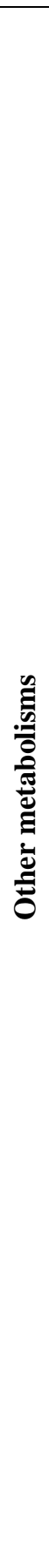 } & Acidobacteria & 2313 & 1974 & 236 & 586 \\
\hline & Actinobacteria & 930 & 1960 & 350 & 246 \\
\hline & Bacteroidetes & 1979 & 6102 & 2528 & 3399 \\
\hline & Deferribacteres & 93 & 154 & 391 & 116 \\
\hline & Chitinivibrionia & 47 & 317 & 11 & 3988 \\
\hline & Parcubacteria & 958 & 713 & 303 & 1039 \\
\hline & Planctomycetes (others) & 5476 & 7700 & 2004 & 238 \\
\hline & Blastopirellula & 199 & 3562 & 65 & 24 \\
\hline & Alphaproteobacteria (others) & 666 & 1330 & 324 & 316 \\
\hline & Hyphomonadaceae & 1 & 1268 & 201 & 28 \\
\hline & Parvularculaceae & 156 & 576 & 54 & 21 \\
\hline & Rhizobiales (others) & 1219 & 422 & 599 & 89 \\
\hline & Pseudahrensia & 204 & 791 & 222 & 86 \\
\hline & Rhodobacteraceae & 1157 & 321 & 327 & 218 \\
\hline & Rhodospirillaceae & 653 & 336 & 52 & 45 \\
\hline & Betaproteobacteria (others) & 29 & 363 & 5 & 10 \\
\hline & Methylotenera & 0 & 1 & 2130 & 36 \\
\hline & Myxococcales & 329 & 2404 & 564 & 922 \\
\hline & Gammaproteobacteria (others) & 2246 & 2749 & 1147 & 526 \\
\hline & Acidiferrobacteraceae & 346 & 9 & 1 & 3 \\
\hline & Alteromonadales & 15 & 530 & 14 & 901 \\
\hline & BD7-8 marine group & 259 & 444 & 500 & 937 \\
\hline & Chromatiales (others) & 62 & 272 & 374 & 11 \\
\hline & CS-B046 group & 3714 & 5 & 101 & 117 \\
\hline & Thiotrichales (others) & 21 & 0 & 0 & 4 \\
\hline & Piscirickettsiaceae (others) & 22 & 0 & 13 & 35 \\
\hline & Piscirickettsiaceae (endosymbionts) & 83 & 27 & 924 & 157 \\
\hline & Kangiella & 19 & 473 & 80 & 6 \\
\hline & Xantomonadales & 1444 & 2522 & 359 & 374 \\
\hline
\end{tabular}


Table 2: continued.

\begin{tabular}{|c|c|c|c|c|c|}
\hline & Taxonomy & $\begin{array}{ll}\text { El } & \text { Cid } \\
\text { MV } & \end{array}$ & $\begin{array}{l}\text { Bonjardim } \\
\text { MV }\end{array}$ & $\begin{array}{l}\text { Al Gacel } \\
\text { MV }\end{array}$ & $\begin{array}{l}\text { Anastasya } \\
\text { MV }\end{array}$ \\
\hline 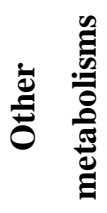 & $\begin{array}{l}\text { Spirochaeta } 2 \\
\text { Verrucomicrobia } \\
\text { Others }\end{array}$ & $\begin{array}{l}858 \\
310 \\
2244\end{array}$ & $\begin{array}{l}39 \\
2135 \\
2452\end{array}$ & $\begin{array}{l}53 \\
306 \\
1669\end{array}$ & $\begin{array}{l}1910 \\
3993 \\
2033\end{array}$ \\
\hline 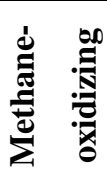 & $\begin{array}{l}\text { Methylococcales (others) } \\
\text { MMG-2 } \\
\text { MMG-3 }\end{array}$ & $\begin{array}{l}17 \\
19 \\
132\end{array}$ & $\begin{array}{l}75 \\
311 \\
105\end{array}$ & $\begin{array}{l}1186 \\
2157 \\
23\end{array}$ & $\begin{array}{l}322 \\
8550 \\
508\end{array}$ \\
\hline 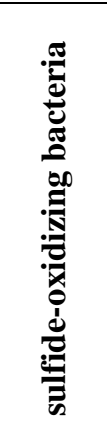 & $\begin{array}{l}\text { Epsilonproteobacteria } \\
\text { Thioalkalispira } \\
\text { Thiogranum } \\
\text { Sedimenticola } \\
\text { Thiohalophilus } \\
\text { Thiotrichaceae (others) } \\
\text { Cocleimonas }\end{array}$ & $\begin{array}{l}46 \\
22 \\
755 \\
13 \\
2034 \\
12100 \\
4\end{array}$ & $\begin{array}{l}73 \\
50 \\
41 \\
1 \\
42 \\
1436 \\
1\end{array}$ & $\begin{array}{l}184 \\
2 \\
7 \\
5080 \\
0 \\
436 \\
850\end{array}$ & $\begin{array}{l}355 \\
857 \\
15 \\
39 \\
47 \\
349 \\
19\end{array}$ \\
\hline 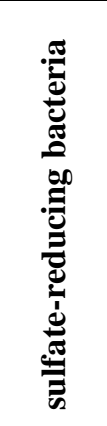 & $\begin{array}{l}\text { Fusibacter } \\
\text { Deltaproteobacteria (others) } \\
\text { Desulfobacterales (others) } \\
\text { Desulfatitalea } \\
\text { Desulfobacter } \\
\text { Desulfosarcina } \\
\text { Desulfopila }\end{array}$ & $\begin{array}{l}136 \\
659 \\
223 \\
0 \\
2 \\
2 \\
0\end{array}$ & $\begin{array}{l}10 \\
594 \\
524 \\
0 \\
4 \\
1 \\
60\end{array}$ & $\begin{array}{l}6 \\
480 \\
2356 \\
900 \\
229 \\
492 \\
268\end{array}$ & $\begin{array}{l}972 \\
343 \\
1853 \\
0 \\
4294 \\
9 \\
739\end{array}$ \\
\hline
\end{tabular}


Table 3: Number of reads related to different archaeal taxa found in the analyzed samples. The group "others" consist on unclassified OTUs and OTUs which represent less than $1.5 \%$ of total relative abundance in the sample. Please notice total number of reads from El Cid MV are much lower than the other samples due to sampling and processing problems.

\begin{tabular}{|c|c|c|c|c|c|}
\hline & Taxonomy & $\begin{array}{ll}\text { El } & \text { Cid } \\
\text { MV } & \end{array}$ & $\begin{array}{l}\text { Bonjardim } \\
\text { MV }\end{array}$ & $\begin{array}{l}\text { Al Gacel } \\
\text { MV }\end{array}$ & $\begin{array}{l}\text { Anastasya } \\
\text { MV }\end{array}$ \\
\hline \multirow{4}{*}{ 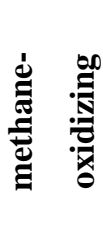 } & ANME-1a & 31 & 0 & 107 & 23 \\
\hline & ANME-1b & 145 & 229 & 87 & 38 \\
\hline & ANME-2a-2b & 117 & 31 & 217 & 103 \\
\hline & ANME-2c & 32 & 389 & 40 & 17 \\
\hline \multirow{2}{*}{ 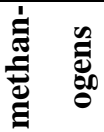 } & Methanosarcinales (others) & 7 & 245 & 4 & 76 \\
\hline & Methanococcoides & 105 & 66 & 26 & 160 \\
\hline \multirow{8}{*}{ 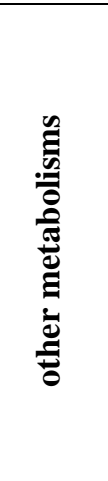 } & Odinarchaeia & 19 & 45 & 24 & 552 \\
\hline & Bathyarchaeia & 74 & 40 & 76 & 39 \\
\hline & Diapherotrites & 9 & 61 & 425 & 4 \\
\hline & Thermoplasmata & 197 & 278 & 1113 & 248 \\
\hline & Woesearchaeota (DHVEG-6) & 1206 & 13055 & 15249 & 11329 \\
\hline & Nitrosopumilaceae (others) & 805 & 1315 & 153 & 11 \\
\hline & Candidatus Nitrosopumilus & 1118 & 5000 & 4678 & 188 \\
\hline & Others & 215 & 169 & 378 & 609 \\
\hline
\end{tabular}




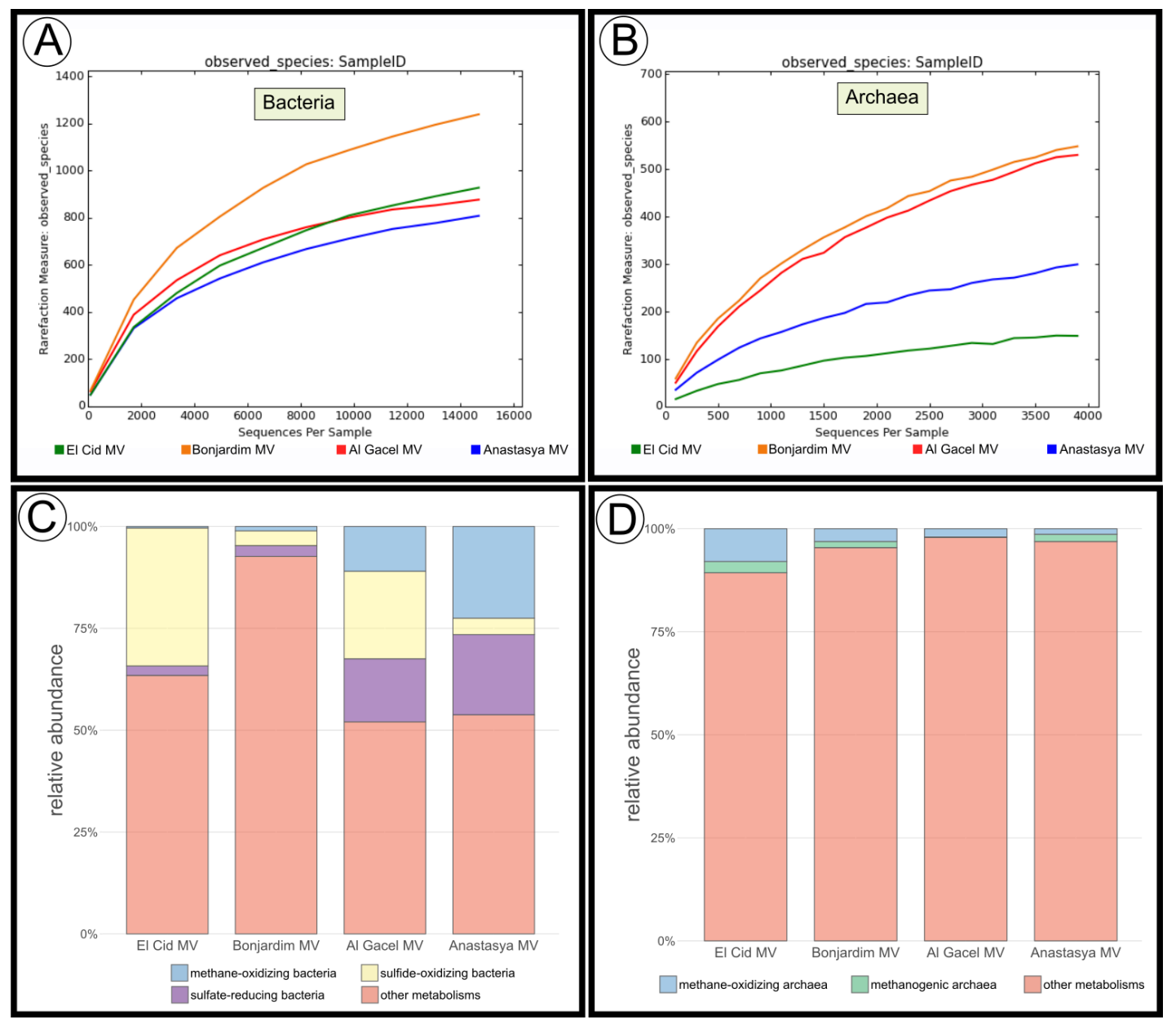

Figure 7: According to prokaryotic environmental DNA analyses of the different sampled worms: AB: representation of the alpha diversity of the samples. C-D: bar chart representation of the microbial communities grouped according to their metabolic preferences.

\subsection{Discussion}

\subsubsection{Endosymbionts in Siboglinidae worms}

Since the first time siboglinids were discovered in 1900s and described by Caullery in 1914 (Tobar-Hernández \& Salazar-Vallejo, 2009), researchers have collected data on their life history characteristics and, in particular, adaptations allowing them to survive in reduced environments at high hydrogen sulfide concentrations and low oxygen (Petersen \& Dubilier, 2009). To date, it has been established that these tube-dwelling annelids harbor chemolithoautotrophic endosymbionts in the super-vasculated 
trophosome (Bright \& Giere, 2005; Southward et al., 2005). Those endosymbionts are facultative free-living bacteria which are acquired from the environment by the worms during their juvenile stage, at the same time as their guts are reduced (Cary et al., 1993; Di Meo et al., 2000). Once they become adults, they have established a permanent mutualistic microbe-animal symbiosis, with the host lacking gut and acquiring organic carbon solely from their endosymbionts (e. g. Nussbaumer et al., 2006). This mechanism of obtaining endosymbionts horizontally from the environment has been described in other animals (Nussbaumer et al., 2006 and references therein).

Most Siboglinidae worms currently described, harbor thiotrophic bacteria in their trophosomes (Petersen \& Dubilier, 2009; Hilário et al., 2011). Though a few studies have shown that some these worms also harbor methanotrophic endosymbionts, i.e. specimens of Siboglinum poseidoni recovered from central Skagerrak (Schmaljohann \& Flügel, 1987), and Sclerolinum contortum from the Haakon Mosby MV (Pimenov et al., 2000) and the Gulf of Cádiz (Rodrigues et al., 2013). Furthermore, Hilario et al. in 2011 presented an evolutionary model representing the common symbionts related to the Siboglinidae major clades (i. e. vestimentiferans, Sclerolinum spp., frenulates and Osedax spp.). In this model, vestimentiferans and Sclerolinum spp. are known to harbor thiotrophic bacteria, while frenulates may harbor thiotrophic or methanotrophic bacteria. Osedax spp. symbionts are known to date to be heterotrophic.

In the current study, endosymbionts from specimens recovered from $\mathrm{El} \mathrm{Cid} \mathrm{MV}, \mathrm{Al}$ Gacel MV and Anastasya MV were detected. Environmental bacterial 16s rDNA from the El Cid MV sample presented an ASV with $99 \%$ similarity to a thiotrophic endosymbiont of Siboglinum worms recovered from Gemini MV in the Gulf of Cádiz (ASV_0; see Rodrigues et al., 2011). Likewise, Al Gacel MV worms revealed high abundance of an ASV with $98 \%$ similarity to Sedimenticola sp., a thiotrophic endosymbiont of Sclerolinum contortum (ASV_4; see Eichinger et al., 2014). Furthermore, we found evidence for methanotrophic bacteria inside of the trophosome (Fig. 2, C-D) of a small siboglinid from the Anastasya MV (attempted to be classified as Siboglinum sp., due to its lack of girdles between the trophosome and opisthosoma; Fig. 2, A; Southward et al., 2005). Previous studies have described the presence of 
Siboglinum sp. worms at this volcano (Rueda et al., 2012). The presence of methanotrophs inside the sampled individuals agrees with a previous report of Siboglinum sp. living in symbiosis with methanotrophic bacteria also in the Gulf of Cadiz, in this case in Captain Arutyunov MV (Rodrigues et al., 2013). Environmental analysis of the bacterial 16s rDNA revealed that the most abundant methane-oxidizing bacteria in Anastasya MV specimens were related to Marine Methylotrophic Group 2 (MMG-2, Methylococcales; Table 2). MMG-2 bacteria have not previously been described as endosymbionts, but MMG-1 and MMG-3 (Ruff et al., 2013). However, since each new generation of siboglinids acquire their endosymbionts from the environment (Nussbaumer et al., 2006), it is possible that MMG-2 bacteria have been adapted as endosymbionts in the Siboglinum sp. worms recovered from the Anastasya MV. Consequently, this study would be the first to attempt to include MMG-2 bacteria as potential endosymbionts of chemosynthetic invertebrates. This suggestion argues for the need to further study the role of MMG-2 bacteria related to siboglinids and other chemosynthetic invertebrates.

\subsubsection{The tube as a new niche}

To date, only few studies have reported microbial organisms related to siboglinid tubes (López-García et al., 2002; Duperron et al., 2009; Petersen et al., 2012). The tubes of all siboglinids have in common that they produce a chitinous matrix secreted by the worm that is incorporated in the tube (Blackwell et al., 1965). Since they are in contact with water and reduced sediments, tubes are rich in minerals and other inorganic compounds which may vary depending on the environment (Duperron et al., 2014). Haas et al. (2009), for instance, observed that the organic tubes were replaced by aragonite after the death of the worms, possibly due to the bacterial communities colonizing the tube.

External and internal colonization of siboglinid tubes has previously been described (López-García et al., 2002; Duperron et al., 2009; Petersen et al., 2012) with highly abundance of Epsilonproteobacteria (López-García et al., 2002; Georgieva et al., 2015). SEM and TEM micrographs showed highly colonized tubes in Al Gacel MV 
specimens (Fig. 4, B; Fig. 5). The biofilm was composed of mostly methanotrophic bacteria forming bacteriocyte-like bodies (Fig. 5, A-C), but also filamentous (Fig. 5, D-E), prosthecate and spirillum-shaped (Fig. 5, F) and rod-shaped bacteria were observed (Fig. 5, G-H). Yet, bacteria penetrating the chitin tube were also detected (Fig. 5, I). Environmental 16s rDNA related to this sample revealed the highly abundance of bacteria related to Methylococcales (Table 2), possibly forming the characteristic found along the microbial biofilm (Fig. 5, A-C). Rod-shaped bacteria could be related to Methylotenera sp. bacteria or sulfate-reducing Deltaproteobacteria, since they are rod-shaped and abundant in this sample (Table 2). Few reads have been related to Hypomonodaceae, prosthecate bacteria which could explain the morphotypes observed on the external biofilm of Al Gacel MV worm (Fig. 5, F). Furthermore, sequences related to Chitinivibrionia bacteria (chitin degraders) were found in the sample, although only in minor amounts. The presence of these bacteria could explain the active penetration of the biofilm inside the tube (Fig. 5, I).

Al Gacel MV specimens represent a good example of how the tubes of siboglinids provide a viable niche for microorganisms. In fact, microbial biofilms are known to be ecosystems themselves, capable of self-regulation in which all microorganisms are linked and provide each other with stable sources of nutrients and protection (e. g. Davey \& O'Toole, 2000). Furthermore, those microorganisms increment the impact of siboglinid worms in the ecosystem, considering them part of the worms' microbiota. However, the stability of these biofilms may be disrupted if the worms die or the source of nutrients decrease, i.e. seepage decreases. This would lead to the decay of the chemosynthetic-based biofilm. For instance, Anastasya MV specimens have remains of the biofilm on the surface of their tubes (Fig. 4, C; Fig. 6). The decay of the microbial biofilm implies a decrease on the consumption of certain compounds present in the environment, such as methane and sulfur compounds. Thus, the rapidly mineralization of the biofilm is expected. High amounts of iron, calcium and sulfur compounds were detected in all the tubes with EDX-analysis, indicating the precipitation of minerals such as pyrite and aragonite (Peckmann et al., 2005; Haas et al., 2009; Georgieva et al., 2015). For instance, the tubes of El Cid MV specimens 
were externally covered by those minerals (Fig. 4, A). The microbial mineralization would also be accompanied by the silicification of the chitin-tube (Fig. 4, E; Georgieva et al., 2015), which eventually mineralized due to the continuous exposure to the environment and more rapidly after the decay of a protective microbial biofilm. Furthermore, if the decay and consequent mineralization of the microbial biofilm occurs due to a decrease of nutrients - i. e. decrease of seepage activity - the tube of siboglinids would be re-colonized by new microorganisms once nutrients are available. Thus, a model has been proposed showing the composition of the different layers given in the tube of a siboglinid worm based on our results and other studies (Fig, 4, F; Peckmann et al., 2005; Haas et al., 2009; Georgieva et al., 2015). Additionally, the high presence of sequences related to chitin-degraders in Anastasya MV samples (Table 2) could explain the active participation of the biofilm on the decay of tubes once the worm die.

Consequently, it is important to consider the tube of siboglinids as an important niche, which increases the biomass of organisms considered to live in these ecosystems and provides a large source of microorganisms which are part of the microbiota of the worms. Further studies focused on the life cycle of these biofilms, as well as their interaction and impact in the environment, are warranted.

\subsubsection{The microbiota of small Siboglinidae worms}

Siboglinidae worms do not only harbor microorganisms in their trophosome, but also on their tubes. In fact, rod-shaped bacteria were observed on Anastasya MV worm, as epibionts (supplementary data Fig. S3). The microorganisms associated with Siboglinidae worms conform the microbiota (or microflora) of these invertebrates. This microbiota is part of its host, and the metabolisms driven by these microorganisms contribute to the ecological impact of the worm on the environment. Worms and microbiota constitute a unique ecological unit, sometimes referred as holobiont (Margulis \& Fester, 1991). Thus, in the same way the community of a mud volcano switches between chemosynthetic and non-chemosynthetic organisms depending on changes of the source of nutrients (i. e. seepage activity), we observed disparity in the 
microbiota of siboglinids sampled from different mud volcanoes and sites with different seepage activity (Figs. 7 \& 8).

El Cid MV and Bonjardim MV specimens were recovered from sites where non-active emission of fluids was detected, and methane concentration was relatively low (70 $90 \mathrm{nM}$ and 50 - 65 nM, respectively; Sánchez-Guillamón et al., 2015) (Fig. 8). However, the site of El Cid MV from where worms were sampled, was surrounded by non-chemosynthetic fauna (shrimps, fish; Fig. 8, A), while Bonjardim MV sampling was performed in an area where patches of reduced sediment (biofilm-like) and dead bivalves were observed (Fig. 8, B). The sampled sediment with the siboglinids emanated a strong smell of hydrogen sulfide, potentially indicating the occurrence of anaerobic oxidation of methane (AOM). Therefore, despite the higher methane values detected in El Cid MV, the sampling site at Bonjardim MV was more affected by seepage activity than the site where siboglinids were sampled in El Cid MV. Interestingly, El Cid MV specimens show relative high number of sequence-reads related to sulfide-oxidizing bacteria and ANME archaea in relation to the other sample (Tables 2 \& 3). Sulfide-oxidizing bacteria belong mainly to an ASV (ASV_0) which relates with a thiotrophic endosymbiont of Siboglinum worms (Rodrigues et al., 2011). The presence of DNA related to ANME, however, may be explained by residual anaerobic oxidation of methane or less likely DNA from inactive cells — DNA rapidly breaks down in the environment. Furthermore, sulfate-reducing bacteria are much less abundant in this sample as compared to known active sites (i. e. Al Gacel MV and Anastasya MV; Tables 2 \& 3). In the case of Bonjardim MV specimens, the smell of hydrogen sulfide may be an indicator of seepage activity, although not as intense as in Al Gacel MV and Anastasya MV sites, where bubbling was observed (Fig. 8, C-D). Sequence reads related to ANME archaea were more frequent in the sample from Bonjardim MV than in found at other locations while sequences from sulfate-reducing bacteria where less frequent at this site. Furthermore, environmental 16S rDNA sequences obtained from Bonjardim MV show the highest alpha diversity among the samples (Fig. 7, A-B). However, the sampling procedure used in this case (ROV vacuum) is imprecise and non-reduced sediment is also taken, potentially increasing 
the diversity of the sample. On the other hand, the Al Gacel MV and Anastasya MV sampling sites showed bubbling of gas methane hydrates (Fig. 8, C-D) with methane concentrations as high as $191 \mathrm{nM}$ at the time of Sclerolinum worm sampling (SánchezGuillamón et al., 2015). At both sites a thick biofilm covering the tube of mainly methanotrophic bacteria was detected - in Anastasya MV specimens only remains of the biofilm were observed - , and environmental $16 \mathrm{~S}$ rDNA revealed a higher presence of methane-oxidizing and sulfate-reducing microorganisms in these samples. Furthermore, Epsilonproteobacteria were more abundant in these samples, which indicate active sites (Sylvan et al., 2012).

This study represents a first insight into the microbiota of Siboglinidae tubeworms and demonstrates the high microbial diversity and variability among individuals located in nearby mud volcanoes. The seepage activity at these sites directly influence the composition of the microbial community (Fig. 7). Furthermore, the presence of other chemosynthetic organisms may also take part in the principal metabolism driven by the worms. For instance, Anastasya MV worms expressed predominance of methane oxidation among sulfide oxidation, which is the principal metabolism driven by the other siboglinids (Fig. 8). This may be due to the presence of Beggiatoa-like biofilms above the worms that consume hydrogen sulfide, displacing siboglinids to acquire a methanotrophic-based lifestyle. Thus, the holobiont of siboglinid worms and their microbiota comprise an ecosystem by itself and, therefore, characterization of the different niches (outside tube colonizers, inside tube colonizers, epibionts and endobionts) may be necessary to improve our knowledge of the tubeworms and their role as microbial reservoirs. 

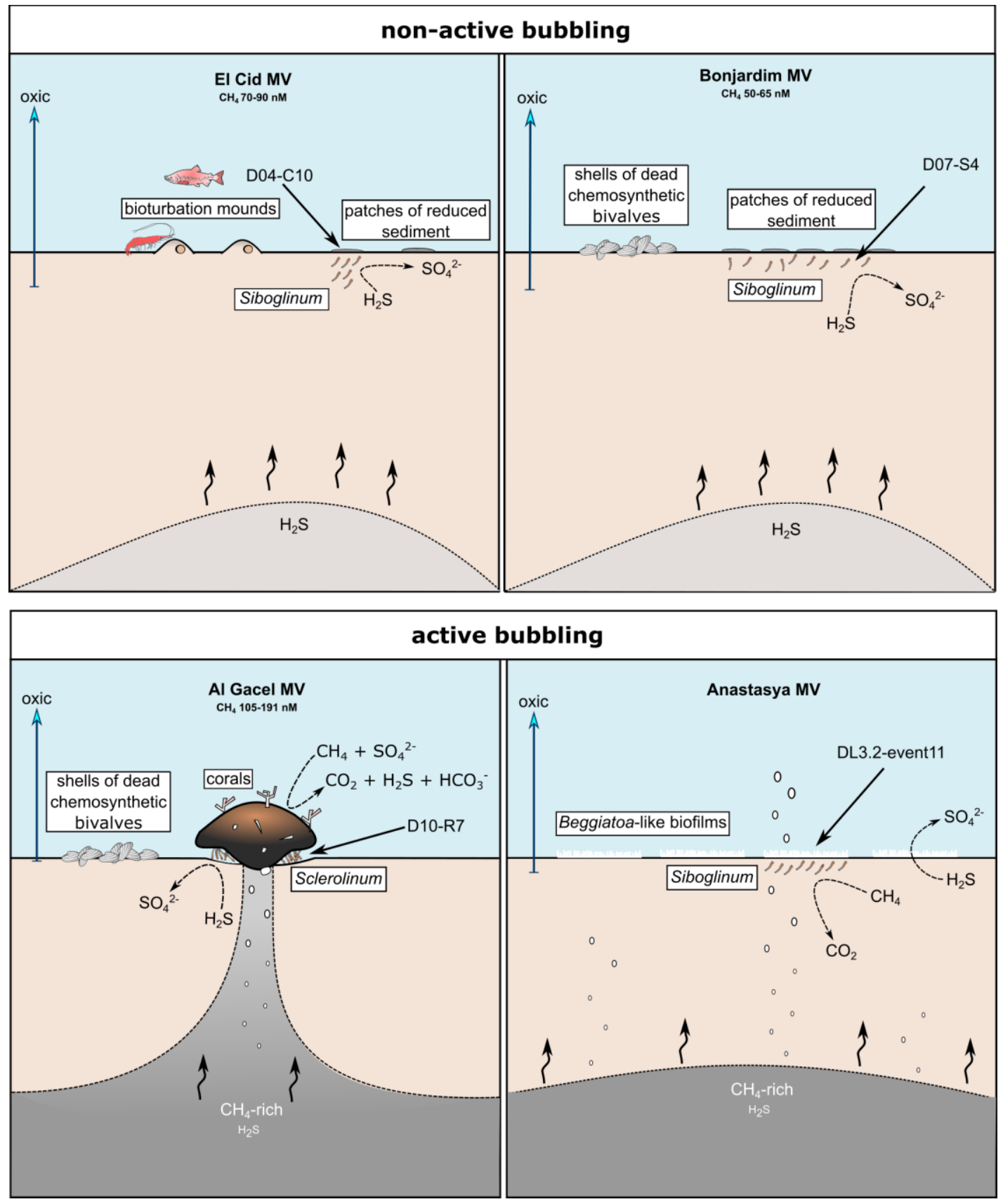

Figure 8: Scheme of the conditions given in the different sampling sites. Notice principal metabolism of siboglinids depending on seepage activity and presence or absence of other chemosynthetic organisms. Methane concentration values are given in Sánchez-Guillamón et al., 2015. 


\subsection{Conclusions}

Small Siboglinidae worms recovered from four different mud volcanoes in the Gulf of Cádiz (El Cid MV, Bonjardim MV, Al Gacel MV and Anastasya MV) appeared to have a higher microbial community related to them than previously realized. In addition to the chemosynthetic endosymbionts harbored inside their trophosome, specimens from Al Gacel MV and Anastasya MV revealed that the tube was colonized by a thick microbial biofilm. We propose Marine Methylotrophic Group 2 as potential endosymbionts of Anastasya MV worms. Furthermore, the external biofilm of the tubes was mostly composed of bacteriocyte-like bodies of methanotrophic bacteria, but other morphotypes like prosthecate, spirillum-like and rod-shaped bacteria were also observed. Comparison of environmental 16S rDNA libraries showed different microbial communities among samples. Since all sampled siboglinids had similar morphology, we assumed that these differences in the microbiota are due to changes in seepage activity at each sampling site, which ultimately influences the microbial community as seeped fluids are the main source of nutrients for microbial primary producers in these ecosystems. This study aimed at increasing our understanding of the inclusive microbiota of siboglinid worms, including the tube as a potential niche for microorganisms. Future studies need to consider the microbial niches provided by these worms and consider the role of siboglinids and their microbiota for ecosystems.

\subsection{References}

Blackwell, J., Parker, K., \& Rudall, K. (1965). Chitin in pogonophore tubes. J. Mar. Biol. Assoc. UK 45, 659-661.

Bright, M., \& Giere, O. (2005). Microbial symbiosis in Annelida. Symbiosis 38, 1-45. Brown, B.V. (1993). A further chemical alternative to critical-pointdrying for preparing small (or large) flies. Fly Times 11, 10.

Caporaso, J. G., Kuczynski, J., Stombaugh, J., Bittinger, K., Bushman, F. D., Costello, E. K., Fierer, N., González Peña, A, Goodrich, J. K., Gordon, J. I., Huttlex, G. A., Kellex, S. T., Knights, D., Koenig, J. E., Ley, R. E., Lozupone, C. A., 
McDonald, D., Muegge, B. D., Pirrung, M., Reeder, J., Sevinsky, J. R., Turnbaugh, P. J., Walters, W. A., Widmann, J., Yatsunenko, T., Zneveld, J., \& Knight, R. (2010). QIIME allows analysis of high-throughput community sequencing data. Nature methods 7(5), 335-336.

Cary, S. C., Warren, W., Anderson, E., \& Giovannoni, S. (1993). Identification and localization of bacterial endosymbionts in hydrothermal vent taxa with symbiont-specific polymerase chain reaction amplification and in situ hybridization techniques. Mol. Mar. Biol. Biotechnol. 2, 51-62.

Chevalier, N., Bouloubassi, I., Birgel, D., Taphanel, M. -H, \& López-García, P. (2013). Microbial methane turnover at Marmara Sea cold seeps: a combined 16S rRNA and lipid biomarker investigation. Geobiology 11, 55-71.

Cunha, M. R., Rodrigues, C. F., Génio, L., Hilário, A., Ravara, A., \& Pfannkuche, O. (2013). Macrofaunal assemblages from mud volcanoes in the Gulf of Cadiz: abundance, biodiversity and diversity partitioning across spatial scales. Biogeosciences 10, 2553-2568.

Davey, M. E., \& O’Tolle, G. A. (2000). Microbial biofilms: from Ecology to Molecular Genetics. Microbiol. Mol. Biol. Rev. 64 (4), 847-867.

Di Meo, C. A., Wilbur, A. E., Holben, W. E., Feldman, R. A., Vrijenhoek, R. C., \& Cary, S. C. (2000). Genetic variation among endosymbionts of widely distributed vestimentiferan tubeworms. Appl. Environ. Microbiol. 66, 651658.

Dubilier, N., Bergin, C., \& Lott, C. (2008). Symbiotic diversity in marine animals: the art of harnessing chemosynthesis. Nat. Rev. Microbiol. 6(10), 725-740.

Duperron, S., Sibuet, M., MacGregor, B. J., Kuypers, M. M., Fisher, C. R., \& Dubilier, N. (2007). Diversity, relative abundance and metabolic potential of bacterial endosymbionts in three Bathymodiolus mussel species from cold seeps in the Gulf of Mexico. Environ. Microbiol. 9(6), 1423-1438.

Duperron, S., De Beer, D., Zbinden, M., Boetius, A., Schipani, V., Kahil, N., \& Gaill, F. (2009). Molecular characterization of bacteria associated with the 
trophosome and the tube of Lamellibrachia sp., a siboglinid annelid from cold seeps in the eastern Mediterranean. FEMS Microbiol. Ecol. 69(3), 395-409.

Duperron, S., Gaudron, S. M., Rodrigues, C. F., Cunha, M. R., Decker, C., \& Olu, K. (2013). An overview of chemosynthetic symbioses in bivalves from the North Atlantic and Mediterranean Sea. Biogeosciences 10(5), 3241-3267.

Duperron, S., Gaudron, S. M., Lemaitre, N., and Bayon, G. (2014). A microbiological and biogeochemical investigation of the cold seep tubeworm Escarpia southwardae (Annelida: Siboglinidae): Symbiosis and trace element composition of the tube. Deep-Sea Res. Pt. I. 90, 105-114.

Edgcomb, V. P., Leadbetter, E. R., Bourland, W., Beaudoin, D., and Bernhard, J. M. (2011). Structured multiple endosymbiosis of bacteria and archaea in a ciliate from marine sulfidic sediments: a survival mechanism in low oxygen, sulfidic sediments? Front. Microbiol., 2 (55), 1-16.

Eichinger, I., Schmitz-Esser, S., Schmid, M., Fisher, C. R., \& Bright, M. (2014). Symbiont-driven sulfur crystal formation in a thiotrophic symbiosis from deepsea hydrocarbon seeps. Env. Microbiol. Rep. 6(4), 364-372.

Génio, L., Johnson, S. B., Vrijenhoek, R. C., Cunha, M. R., Tyler, P. A., Kiel, S., \& Little, C. T. (2008). New record of Bathymodiolus mauritanicus Cosel 2002 from the Gulf of Cadiz (NE Atlantic) mud volcanoes. J. of Shellfish Res. 27(1), 53-61.

Georgieva, M. N., Little, C. T. S., Ball, A. D., \& Glover, A. G. (2015). Mineralization of Alvinella polychaete tubes at hydrothermal vents. Geobiology 13(2), 152169.

Guezi, H., Boutet, I., Andersen, A. C., Lallier, F. H., \& Tanguy, A. (2014). Comparative analysis of symbiont ratios and gene expression in natural populations of two Bathymodiolus mussel species. Symbiosis 63(1), 19-29.

Haas, A., Little, C. T. S., Sahling, H., Bohrmann, G., Himmler, T., \& Peckmann, J. (2009). Mineralization of vestimentiferan tubes at methane seeps on the Congo deep-sea fan. Deep-Sea Res. Pt. I 56, 283-293. 
Hilário, A., Capa, M., Dahlgren, T. G., Halanych, K. M., Little, C. T., Thornhill, D. J., ... \& Glover, A. G. (2011). New perspectives on the ecology and evolution of siboglinid tubeworms. PloS one, 6(2), e16309.

Jannasch, H. W., and Mottl, M. J. (1985). Geomicrobiology of deep-sea hydrothermal vents. Science, $229,717-725$.

Jannasch, H. W. (1989). Chemosynthetically sustained ecosystems in the deep sea. In: Schlegel HG, Bowien B (eds) Autotrophic bacteria. Springer, Berlin, Heidelberg, New York, pp 147-166.

Kalyuzhnaya, M. G., Bowerman, S., Lara, J. C., Lidstrom, M. E., \& Chistoserdova, L. (2006). Methylotenera mobilis gen. nov., sp. nov., an obligately methylamineutilizing bacterium within the family Methylophilaceae. Int. J. Syst. Evol. Micr. 56(12), 2819-2823.

Kimura, H., Sato, M., Sasayama, Y., \& Naganuma, T. (2003). Molecular characterization and in situ localization of endosymbiotic 16S ribosomal RNA and RuBisCO genes in the pogonophoran tissue. Mar. Biotech. 5(3), 261-269.

Levin, L. A., Baco, A. R., Bowden, D. A., Colaco, A., Cordes, E. E., Cunha, M. R., Demopoulos, A. W. J., Gobin, J., Grupe, B. M., Le, J., Metaxas, A., Netburn, A. N., Rouse, G. W., Thurber, A. R., Tunnicliffe, V., Van Dover, C. L., Vanreusel, A., and Watling, L. (2016). Hydrothermal vents and methane seeps: rethinking the sphere of influence. Front. Mar. Sci. 3(72), 1-23.

Little, C. T. S., Herrington, R. J., Maslennikov, V., \& Zaykov, V. (1998). The fossil record of hydrothermal vent communities. Geol. Soc. Spec. Publ. 148, 259270.

López-García, P., Gaill, F., \& Moreira, D. (2002). Wide bacterial diversity associated with tubes of the vent worm Riftia pachyptila. Environ. Microbiol. 4(4), 204 215.

Lösekann, T., Robador, A., Niemann, H., Knittel, K., Boetius, A., \& Dubilier, N. (2008). Endosymbioses between bacteria and deep-sea siboglinid tubeworms from an Arctic Cold Seep (Haakon Mosby Mud Volcano, Barents Sea). Environ. Microbiol. 10(12), 3237-3254. 
Magalhães, V. H., Pinheiro, L. M., Ivanov, M. K., Kozlova, E., Blinova, V., Kolganova, J., ... \& Díaz-del-Río, V. (2012). Formation processes of methanederived authigenic carbonates from the Gulf of Cadiz. Sediment. Geol. 243, $155-168$.

Margulis, L. and Fester, R. (Eds.). (1991). Symbiosis as a source of evolutionary innovation, MIT Press, $470 \mathrm{pp}$.

Martin, M. (2011). Cutadapt removes Adapter Sequences from High-Throughput Sequencing Reads, EMBnet.jounal, 10-12.

Masella, A. P., Bartram, A. K., Truszkowski, J. M., Brown, D. G., \& Neufeld, J. D. (2012). PANDAseq: paired-end assembler for illumina sequences. BMC bioinformatics, 13(31), 1-7.

Niemann, H., Duarte, J., Hensen, C., Omoregie, E., Magalhães, V. H., Elvert, M., ... \& Boetius, A. (2006). Microbial methane turnover at mud volcanoes of the Gulf of Cadiz. Geochim. Cosmochim. Ac. 70(21), 5336-5355.

Nussbaumer, A. D., Fisher, C. R., \& Bright, M. (2006). Horizontal endosymbiont transmission in hydrothermal vent tubeworms. Nature letters 441, 345-348.

Ott, J., Bright, M., \& Bulgheresi, S. (2004). Marine microbial thiotrophic ectosymbioses. Oceangr. Mar. Biol. Annu. Rev. 42, 95-118.

Ozaki, S., Kishimoto, N., \& Fujita, T. (2007). Change in the predominant bacteria in a microbial consortium cultured on media containing aromatic and saturated hydrocarbons as the sole carbon source. Microbes Environ. 22(2), 128-135.

Peckmann, J., Little, C. T. S., Gill. F., \& Reitner, J. (2005). Worm tube fossils from the Hollard Mound hydrocarbon-seep deposit, Middle Devonian, Morocco: Palaeozoic seep-related vestimentiferans? Palaeogeogr. Palaeoecl. 227, 242257.

Petersen, J. M., \& Dubilier, N. (2009). Methanotrophic symbioses in marine invertebrates. Environ. Microbiol. Rep. 1(5), 319-335.

Petersen, J. M., Wentrup, C., Verna, C., Knittel, K., \& Dubilier, N. (2012). Origins and evolutionary flexibility of chemosynthetic symbionts from deep-sea animals. The Biological Bulletin, 223(1), 123-137. 
Pimenov, N., Savvichev, A., Rusanov, I., Lein, A., Egorov, A., Gebruk, A., ... \& Vogt, P. (1999). Microbial processes of carbon cycle as the base of food chain of Håkon Mosby Mud Volcano benthic community. Geo-Mar. Letters 19(1), 8996.

Pimenov, N. V., Savvichev, A. S., Rusanov, I. I., Lein, A. Y., \& Ivanov, M. V. (2000). Microbiological processes of the carbon and sulfur cycles at cold methane seeps of the North Atlantic. Microbiology 69(6), 709-720.

Poindexter, J. S. (2006). Dimorphic prosthecate bacteria: The genera Caulobacter, Asticcacaulis, Hyphomicrobium, Pedomicrobium, Hyphomonas, and Thiodendron, In: The Prokaryotes, 3rd ed.; Truper, H. G., Drowkin, M., Harder, W., Schleifer, K. H., (Eds.). Springer, New York, pp 72.

Raggi, L., Schubotz, F., Hinrichs, K. U., Dubilier, N., \& Petersen, J. M. (2013). Bacterial symbionts of Bathymodiolus mussels and Escarpia tubeworms from Chapopote, an asphalt seep in the southern Gulf of Mexico. Environ. Microbiol. 15(7), 1969-1987.

Rincón-Tomás, B., Duda, J.-P., Somoza, L., González, J., Schneider, D., Medialdea, T., Madureira, P., Hoppert, M., \& Reitner, J. (2018). Cold-water corals and hydrocarbon-rich seepage in the Pompeia Province (Gulf of Cádiz) — living on the edge. Biogeosciences Discussions.

Rodrigues, C. F., Webster, G., Cunha, M. R., Duperron, S., \& Weightman, A. J. (2010). Chemosynthetic bacteria found in bivalve species from mud volcanoes of the Gulf of Cadiz. FEMS Microb. Ecol. 73(3), 486-499.

Rodrigues, C. F., Hilário, A., Cunha, M. R., Weightman, A. J., \& Webster, G. (2011). Microbial diversity in Frenulata (Siboglinidae, Polychaeta) species from mud volcanoes in the Gulf of Cadiz (NE Atlantic). Antonie Van Leeuwenhoek, 100(1), 83-98.

Rodrigues, C. F., Hilário, A., \& Cunha, M. R. (2013). Chemosymbiotic species from the Gulf of Cadiz (NE Atlantic): distribution, life styles and nutritional patterns. Biogeosciences 10, 2569-2581. 
Roeselers, G., \& Newton, I. L. (2012). On the evolutionary ecology of symbioses between chemosynthetic bacteria and bivalves. Appl. Microbiol. Biot. 94(1), $1-10$.

Rueda, J. L., González-García, E., Marina, P., Oporto, T., Rittierott, C., \& LópezGonzález, N. (2012). Biodiversity and geodiversity in the mud volcano field of the Spanish margin (Gulf of Cádiz). Symposium MIA12.

Ruff, S. E., Arnds, J., Knittel, K., Amann, R., Wegener, G., Ramette, A., \& Boetius, A. (2013). Microbial Communities of Deep-Sea Methane Seeps at Hikurangi Continental Margin (New Zealand). PLoS ONE, 8(9), 1-16.

Sánchez-Guillamón, O., García, M. C., Moya-Ruiz, F., Vázquez, J. T., Palomino, D., Fernández-Puga, M. C., \& Sierra, A. (2015). A preliminary characterization of greenhouse gas $\left(\mathrm{CH}_{4}\right.$ and $\left.\mathrm{CO}_{2}\right)$ emissions from Gulf of Cádiz mud volcanoes. VIII Symposium MIA15, 2015.

Schmaljohann, R., \& Flügel, H. J. (1987). Methane-oxidizing bacteria in Pogonophora. Sarsia 72(1), 91-98.

Sylvan, J. B., Toner, B. M., \& Edwards, K. J. (2012). Life and Death of Deep-Sea Vents: Bacterial Diversity and Ecosystem: Succession on Inactive Hydrothermal Sulfides. Am. Soc. Microbiol. 3(1), e00279-11.

Southward, E. C., Schulze, A., \& Gardiner, S. L. (2005). Pogonophora (Annelida): form and function. Hydrobiologia 535, 227-251.

Stewart, F. J., Newton, I. L., \& Cavanaugh, C. M. (2005). Chemosynthetic endosymbioses: adaptations to oxic-anoxic interfaces. Trends in microbiology, 13(9), 439-448.

Thornhill, D. J., Fielman, K. T., Santos, S. R., \& Halanych, K. M. (2008). Siboglinidbacteria endosymbiosis: A model system for studying symbiotic mechanisms. Communicative \& integrative biology 1(2), 163-166.

Tobar-Hernández, M A., \& Salazar-Vallejo, S. I. (2009). Siboglinidae Caullery, 1914. In: Poliquetos (Annelida: Polychaeta). León-González, J. A., Bastida-Zavala, J. R., Carrera-Parra, L. F., García-Garza, M. E., Peña-Rivera, A., SalazarVallejo, S. I., \& Solís-Weiss, V. (Eds.). 737 pp. 
Van Dover, C.L. (2000). The Ecology of Deep-Sea Hydrothermal Vents. Princeton, NJ, USA: Princeton University Press, 424 pp.

Yilmaz, P., Parfrey, L.W., Yarza, P., Gerken, J., Pruese, E., Quast, C., Schweer, T., Peplies, J., Ludwig, W., and Glöckner, F. O. (2014). The SILVA and 'Allspecies Living Tree Project (LTP)' taxonomic frameworks, Nucleic Acids Res., 42.

Zhang, J., Kobert, K., Flouri, T., \& Stamatakis, A. (2013). PEAR: a fast and accurate Illumina Paired-End reAd mergeR. Bioinformatics, 30(5), 614-620.

\subsection{Supplementary data}

\subsubsection{Worm observed inside its tube in Al Gacel MV sample}
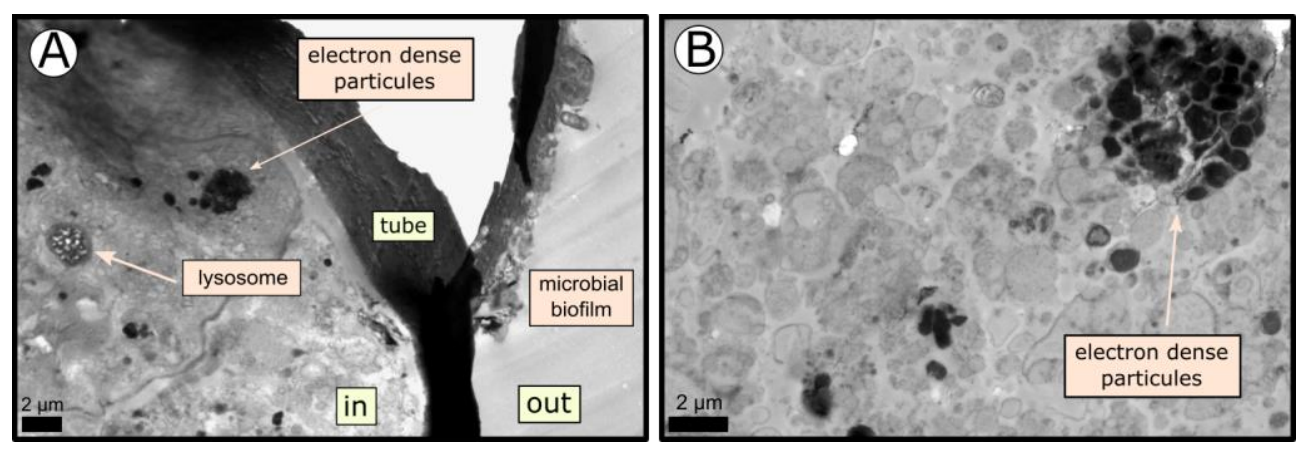

Figure S1: TEM micrographs of siboglinids from Al Gacel MV.

\subsubsection{EDX analysis}

El Cid MV specimens expressed high values of iron and calcium along the tube, except on the inside layer (Fig. S2). Outside layer presented phosphorous and silica (spektrum 4). There were differences in the different internal layer, with variations in phosphorous, aluminum and silica. Magnesium was detected in one of the layers. Filamentous matrix (spektrum 6) was richer in phosphorous and presented lower silica. Layer with silica-balls had pick-signals in silica and aluminum (spektrum 2). The inside layer had no calcium, but maybe it was just not detected. Furthermore, Anastasya MV tubes presented iron and sulfur values homogenous along the tube. The outsider layer revealed also notable presence of silica and alluminium, and picks of 
calcium locally. Likewise, in Al Gacel MV tube sulfur and silica were homogenous. Outside layers presented locally high picks of sulfur and iron, while internal layer had some aluminum. One internal layer also presented a pick-signal of sulfur. The most inside layer (facing worm), keeps the homogeneity.
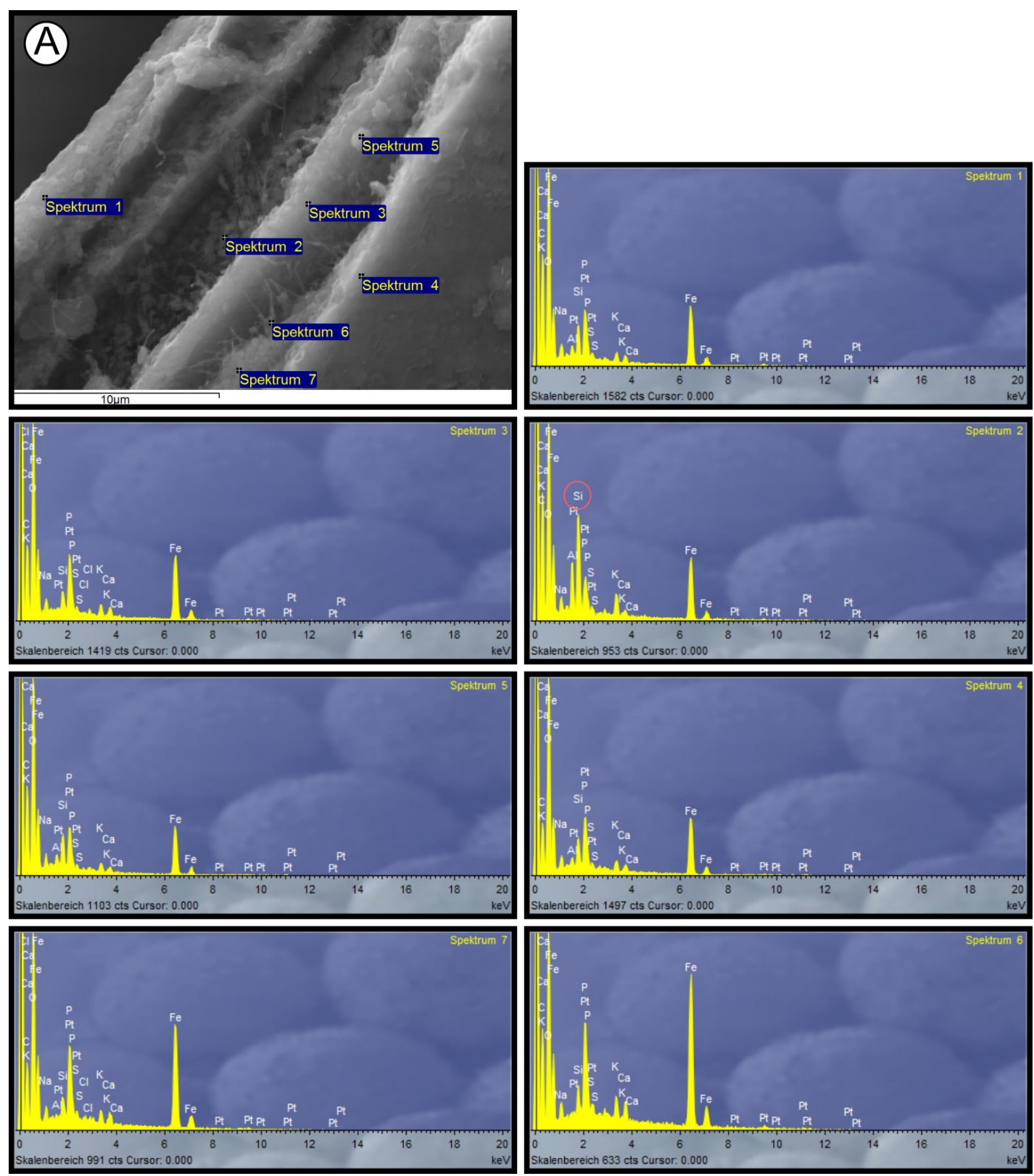

Figure S2: EDX analysis performed on the disrupted tube from a specimen from El Cid MV. Notice the pick-signal of silica in spektrum 2. 
3.6.3 Epibionts of Anastasya MV worm

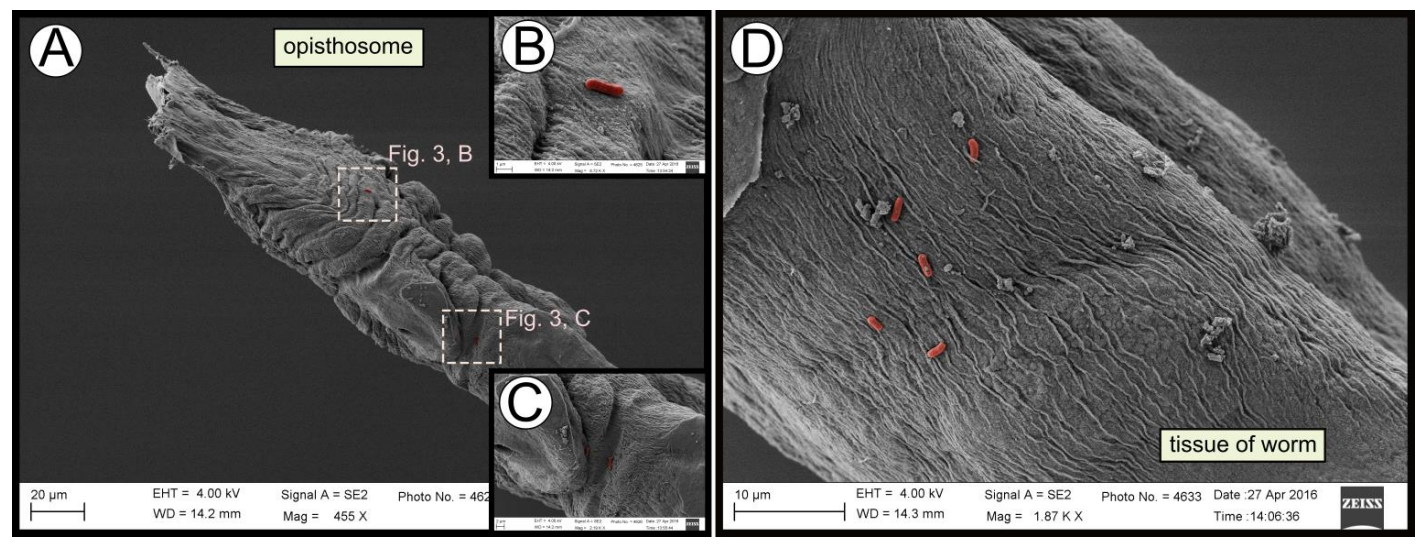

Figure S3: SEM micrographs revealed the presence of epibionts on the surface of the worms' tissue. 


\section{General discussion}

The study of symbiotic adaptation of prokaryotes in extreme deep-sea environments is focused on understanding why these organisms adapt to reduced deep-sea ecosystems via symbiosis and the benefits it may cause for them and the community. As prokaryotes, they occupy any ecological niches that evolved during the Precambrian. Most eukaryotes, in particular multicellular organisms, are metabolically less diverse and stick to a narrower range of physical conditions and nutrients. Thus, prokaryotes are found everywhere and yet no natural place is known to be free of microbes - not even the Antarctica. In fact, some hyperthermophiles happen to grow at up to $110^{\circ} \mathrm{C}$ (Pagé et al., 2008). Furthermore, the reminiscence of hydrothermal vents and cold seeps to habitats given in early biosphere indicates that metabolisms occurring in those habitats may be primordial and similar to the metabolisms driven by the first living organisms. For instance, methanogenesis and anaerobic oxidation of methane are widely distributed in these ecosystems and are known to be part of the early biosphere, with evidences dating from 3.5 Ga (Ueno et al., 2006; Wolfe \& Fournier, 2018) and 2.7 Ga ago (Hinrichs, 2002), respectively. The anaerobic oxidation of methane (AOM) is considered to be the major reaction in cold seeps and in most of the cases cannot be driven only by archaea and it needs the cooperative participation of bacterial sulfate reducers (Boetius et al., 2000; Valentine \& Reeburg, 2000; Blumenberg et al., 2004; Reitner et al., 2005b). Thus, the still prevalence of symbiosis to perform this reaction $(\mathrm{AOM})$ in modern ecosystems demonstrate that symbiosis is successful and more important in evolution as thought until now.

Nowadays, theoretical and evolutionary biology are based on the believe that random genetical mutations and epigenetics are the major motor of evolution, understanding natural selection as a competition between organisms, in which the best adapted will survive. The predominance of symbiosis in extreme deep-sea environments is of great importance for theoretical and evolutionary biology, since it reflects the benefits and abundance of it in punctual and specialized ecosystems. We discuss why symbiosis is 
important and contemplate the need of changing the way of understanding evolutionary biology, whose reflection is the phylogenetic tree of life.

\subsection{Symbiosis in the Gulf of Cádiz}

The Gulf of Cádiz (Fig. 2 from chapter 1) is a region with sediments rich in hydrocarbons, mostly methane. Due to the high tectonic activity of the region, reservoirs of hydrocarbon-rich fluids are subjected to high pressures, leading to the upward migration of these fluids (Medialdea et al., 2009). They are ultimately ejected onto the seafloor, forming seepage-related structures such as pockmarks and mud volcanoes. These sites are considered cold seeps, characterized by diffused and dripping-like seepage of fluids, normally at water temperatures of the deep-sea environment. However, eruptions in mud volcanoes may occur and lead to the extrusion of reduced sediment, called mud breccia (León et al., 2012).

The Gulf of Cádiz harbors up to 50 mud volcanoes, in which many of them extensive chemosynthesis-based communities have been described (e. g. Rueda et al., 2012; Cunha et al., 2013; Rodrigues et al., 2013b). These communities are characterized by invertebrates, i. e. bivalves and tubeworms, which harbor chemosynthetic symbionts in their organs. These endosymbionts may be methanotrophs or thiotrophs, although other endosymbionts have also been described (Rodrigues et al., 2013a). Furthermore, extensive bacterial mats and authigenic carbonates derived from the anaerobic oxidation of methane (AOM) are also commonly found in the region. The Gulf of Cádiz is one of the most important regions rich in hydrocarbons and cold seep community, together with the Haakon Mosby Mud Volcano and the Gulf of Mexico. Its location and accessibility give us the opportunity to deeply study the area and understand the relationship between chemosynthetic-based communities and cold seeps.

Due to the current activity of the region, many of the mud volcanoes studied until now are known to be active (see Van Rooij et al. 2005 for a review). New technologies make possible to reach easily the mud volcanoes, which some of them are found at $3000 \mathrm{~m}$ depth, like the Bonjardim MV (Fig. 2 from chapter 1). Furthermore, the 
potential release of high amounts of methane and other compounds into the atmosphere attracts the attention not only of the marine biologists and geologists, but of the scientific and political communities due to its potential impact on global warming.

\subsubsection{Anaerobic oxidation of methane driven in symbiosis}

The anaerobic oxidation of methane (AOM) is the mechanism by which methane is consumed in the absence of oxygen. It is considered one of the most prevalent metabolisms in cold seeps and the major sink of methane in the deep-sea ocean, consuming up to $5-10 \%$ the net atmospheric methane flux (Valentine \& Reeburgh, 2000). Electron acceptors for this reaction are normally oxidized nitrogen compounds (i. e. $\mathrm{NO}_{3}{ }^{-}$and $\mathrm{NO}_{2}$ ), metals such as iron and manganese, and sulfate (Cui et al., 2015). The latter is the most used in deep-sea environments, where AOM is driven via symbiosis by ANaeobic Methanotrophic (ANME) archaea coupled to sulfate-reducing bacteria (SRB). As a by-product calcium carbonates are formed, and their presence can be used as an indicator of current or past methane-rich seepage (e. g. Peckmann et al., 1999, 2001; Reitner et al., 2005a, 2005b).

As mentioned above, hydrocarbon-rich seepage in the Gulf of Cádiz currently occurs and the presence of AOM has been reported from many sites in the region (e. g. Niemann et al., 2006; Sommer et al., 2009; Wehrmann et al., 2011; Rodrigues et al., 2013; this study). Our collected data show that AOM occurs widespread in pockmarks (chapters 2 and 3), diapir ridges (chapter 2), under Beggiatoa-like biofilms (chapter 3 and Fig. S1) and in reduced sediments, such as mud breccia (chapter 3). This symbiotic metabolism was always observed associated to siboglinid worms, except in the diapiric ridges, maybe due to the lack of proper sampling for the search of siboglinids.

In cold seeps, the impact of symbiotic AOM coupled to sulfate is such that its occurrence sustains all other major living forms in these ecosystems. This metabolism increases the production of hydrogen sulfide $\left(\mathrm{H}_{2} \mathrm{~S}\right)$ (e. g. Boetius et al., 2000), needed for thiotrophic organisms (like Beggiatoa-like biofilms, siboglinid worms and other invertebrates) to fix inorganic carbon. Likewise, the consumption of many of the 
reduced compounds before they reach the water column, maintains the anoxic-oxic interface lower and allows aerobic organisms to colonize those active sites. Furthermore, the formation of carbonates provides hard substrata needed by coldwater corals to settle and develop, as well as they reduce acidification and toxics in the environment which may be harmful also for those corals (see the buffer effect in chapter 2). Small AOM carbonate-clasts (Fig. S2), normally found in the reduced sediment, may also be beneficial for small siboglinids and other invertebrates by increasing the porosity of the sediment and providing better filtration of oxygen into the sediment.

Although AOM-related microorganisms are highly abundant in cold seeps, they need anaerobic conditions to survive and therefore are not good candidates to live in symbiosis with aerobic organisms such as animals. However, they all are always related to seepage and make it possible to coexist and share out the habitat and resources by colonizing different ecological niches.

\subsubsection{Characteristic chemosynthetic invertebrates}

The Gulf of Cádiz, as well as other extreme deep-sea environments, is characterized by the presence of certain families of invertebrate animals, which are adapted to the conditions given in these ecosystems and feed directly from the seeped fluids by virtue of chemosynthetic symbionts (see Cavanaugh et al. 2006 and Dubilier et al. 2008 for a review). They are more sensitive to changes in seepage activity, and commonly empty shells of dead bivalves or empty siboglinid tubes are found even when bacterial mats and AOM-related microorganisms are still feeding from the seeped fluids (e. g. Fig. 4, B from chapter 2; Fig. 1 from chapter 3).

Common chemosynthetic invertebrates in the Gulf of Cádiz are solemyid (Solemya and Acharax), vesicomyid (Calyptogena and Vesicomya) and Lucinoma clams (Rueda et al., 2012; 2016; Cunha et al., 2013; Rodrigues et al., 2013), Bathymodiolus mussels (Rodrigues et al., 2013), frenulate tubeworms from the genus Siboglinum, Oligobrachia and Polybrachia (Pinheiro et al., 2003; Sommer et al., 2009; Rueda et al., 2012; Rodrigues et al., 2013; this study) and Sclerolinum tubeworms (Rodrigues 
et al., 2013; this study). Thiotrophic Gammaproteobacteria are the most common endosymbionts (Duperron et al., 2013) and are normally acquired horizontally from the environment (Hilário et al., 2011; Roeselers \& Newton, 2012). Since AOM is the major sink of methane and produces $\mathrm{H}_{2} \mathrm{~S}$ as a by-product, it is reasonable that chemosynthetic invertebrates feed on $\mathrm{H}_{2} \mathrm{~S}$ instead of $\mathrm{CH}_{4}$. Both metabolisms provide the same amount of free energy (Petersen, 2009) and $\mathrm{H}_{2} \mathrm{~S}$ reaches easily the water column, as $\mathrm{CH}_{4}$ is mostly consumed before. Furthermore, the acquisition of methanotrophic bacteria as endosymbionts (Fig. 2 from chapter 3) may be due to higher emission of $\mathrm{CH}_{4}$ in those regions. Some animals harbor methanotrophic Gammaproteobacteria, such as Siboglinum and Bathymodiolus (Rodrigues et al., 2013; this study). Yet, some mytilid mussels, i. e. Idas sp. and Bathymodiolus spp., have been reported to harbor two types of thiotrophic bacteria, both thiotrophic and methanotrophic bacteria, or even methylotrophs and Bacteriodetes (see Duperron et al., 2013 for a review). Additionally, symbionts are also described to live extracellularly in some hosts (i. e. yeti crab, some mussels; see Dubilier et al., 2008 for a review).

Sulfide-oxidizing organisms in reduced environments are mainly Gammaproteobacteria and Epsilonproteobacteria. Interestingly, invertebrates seem to prefer Gammaproteobacteria as endosymbionts (and vice versa) and each new generation is capable of acquiring specifically Gammaproteobacteria from the pool of microorganisms given in the environment. In fact, previous studies have identified different clades of endosymbionts, but all belonging to Gammaproteobacteria (Dubilier et al., 2008). Thus, it must exist sort of a co-evolution (Cavanaugh et al., 2006; Roeselers \& Newton, 2012). 


\subsubsection{Symbionts as part of the holobiont}

Besides their symbionts, animals (and multicellular organisms in general) live in a cohesive relationship with a high diversity of microbes (including unicellular eukaryotes). These microorganisms constitute the so-called microbiota of a multicellular organism and includes epibionts and endobionts, symbionts and commensalistic microorganisms. Nowadays, it is highly debated whether or not the combination of host plus its microbiota, known as holobiont, constitute a symbiotic relationship, in which they act as a one unit of selection, having properties similar to an individual organism, i. e. a superorganism (Margulis \& Fester, 1991). Although there is an appreciation of co-evolution between a host and its microbiota (Rosenberg et al., 2009), this adaptation is not necessary due to an organismalistic* relationship, and many microorganisms may persist or stay for a short-term without causing great changes in their host physiology (Bordenstein \& Theis, 2015; O’ Malley, 2017). For instance, studies focused on cold-water corals have reported the existence of a core microbiome, which does not vary between organisms of the same species, but varies from other cold-water corals and from the microorganisms present in the environment (Hansson et al., 2009; Kellogg et al., 2017). However, the majority of the microbiome does not belong to this microbial core and differs between locations and even specimens of the same species.

\section{*Organismalism vs. Individualism}

In terms of theoretical biology, organismalism refers to biological entities as the result of the interaction between the hosts and their microbiota, all as a one living unit. On the contrary, individualism refers to single organisms as singles biological entities, without including interactions with tighly related microorganisms.

Conclusively, a holobiont should be considered as an ecological unit, more than a superorganism (Douglas \& Werren, 2016 and references therein). This means that a 
diversity of interactions may occur inside of these ecosystems, in the same way occurs in ecosystems like hydrothermal vents and cold seeps. Symbiosis, commensalism, nutritional dependency and even parasitism, they are all part of a holobionts ecosystem. Furthermore, some organisms belonging to a particular ecosystem (e. g. hydrothermal vents, Lophelia corals), may be not exclusive of that ecosystem and may live also in other ecosystems (e. g. cold seeps, Madrepora corals). Likewise, some organisms may not be able to live in other ecosystems, due to symbiotic dependency or nutritional requirements (e. g. Osedax worm in whale falls, the microbial core of Madrepora corals). The existence of a permanent microbial core, however, does indicate a dependency between the microorganisms and the host, suggesting a symbiotic relationship. Further studies need to be performed on the ecology of holobionts, for a better understanding of the host-microbiome interaction.

\subsection{Adaptation of prokaryotes in extreme deep-sea environments}

Piezophilic microorganisms living in the deep-sea at high hydrostatic pressure have developed a variability of physiological strategies to thrive in these conditions. In fact, they need to be adapted also to cold temperatures (psychrophiles) or extremely high temperatures (thermophiles and hyperthermophiles) in case they live in hydrothermal vents. For instance, thermophilic organisms have less flexible cell wall and membranes, increasing the melting temperature and resistance to denaturation (Koga, 2012). Furthermore, their proteins have a high number of large hydrophobic residues and interactions between subunits (Reed et al., 2013; Wang et al., 2015), and they are normally characterized by a high content of G-C nucleotides (Battistuzzi \& Hedges, 2009). Likewise, psychrophiles produce higher content of unsaturated and short-chain fatty acids in their membranes to increase fluidity (Bartlett, 1999; D'Amico et al., 2006), as well as increase their proteins' flexibility using mechanisms similar to those from thermophiles (Reed et al., 2013; De Maayer, 2014). Interestingly, genomes of piezophiles have been found to contain elongated helices in the 16S rRNA genes, improving the ribosome function (Lauro et al., 2007). Moreover, according to Hay et 
al. 2009, adaptations in the proteins of piezophiles seem to be secondary to their adaptations to temperature.

Horizontal gene transfer (HGT; Ochman et al., 2000) between prokaryotes - besides mutations of their own genetic material - plays an important role in their evolutionary physiological modifications. They exchange DNA material through conjugation or phages, acquiring the machinery and genes they need under certain environmental pressure. This phenomenon results into a higher malleability of the microorganism's metabolism, capable of using different energy and carbon sources depending on the limiting factors of the environment. For instance, sulfide-oxidizing endosymbiotic Gammaproteobacteria have strongly similar pathways to use both sulfide and thiosulfate, even though they are phylogenetically divergent (Kleiner et al., 2012). Similarly, MxaF gene (coding for the large unit of the methanol dehydrogenase) occurs in many methanotrophic taxa (Methylococcaceae, Methylocystaceae and Beijerinckiaceae), but 16S rRNA analyses support the evolutionary divergence of these clades (Lau et al., 2013). Thermotaga spp. bacteria even share strong homologies with hyperthermophilic archaea, indicating an extensive inter-domain HGT (Nelson et al., 1999) Therefore, phylogenetic studies face a great challenge when it comes to discriminate if the origin of a share gene between clades is due to evolutionary divergence or HGT (e. g. Battistuzzi \& Hedges, 2009).

Symbiotic adaptions are also widely distributed between prokaryotes in extreme deepsea environments (e. g. Dubilier et al., 2008). It is the predominant form of chemosynthesis, major metabolism of reduced environments and nutritional basis of these ecosystems (Dubilier et al., 2008; Duperron et al., 2013). The anaerobic oxidation of methane and chemosynthetic invertebrates are the most characteristic features of reduced deep-sea environments and, interestingly, they occur due to symbiosis (see section 4.1). In fact, these mutualistic interactions must have existed for a long time, and certain dependency is observed between the implied organisms. For instance, the anaerobic oxidation of methane in hydrothermal vents and cold seeps is mostly feasible by the symbiosis of ANME archaea and SRB. Decoupling ANMESRB consortia has only been possible by the addition of soluble oxidized metals or 
anthraquinone-2,6-disulfonate (AQDS), although it caused a loss of fitness in SRB (Scheller et al., 2016). Furthermore, Gammaproteobacteria in extreme deep-sea environments have adapted to extreme deep-sea environments by becoming endosymbionts of chemosynthetic invertebrates. They have reduced their genomes and lost genes related to DNA repair (Zientz et al., 2004; Minic, 2009), as chloroplasts and mitochondria did (Odintsova \& Yurina, 2003; Embley \& Martin, 2006).

Additionally, new studies are focusing on direct interspecies electron transfer (DIET), a mechanism widely distributed between prokaryotes (e. g. Summers et al., 2010; Rotaru \& Thamdrup, 2016), which reflects the strength of symbiotic relations between organisms. However, this mechanism is not well understood and the implications of DIET for microbial ecology are still to be discovered.

\subsubsection{Symbiosis and the origin of life}

Earliest credible fossil records of anaerobic oxidation of methane date from $2.7 \mathrm{Ga}$ ago (Hinrichs, 2002), right before the Great Oxygenation Event (ca 2.4 Ga ago; Holland, 2002). Levels of methane were high in the atmosphere and the given conditions were similar to those in hydrothermal vents, i. e. optimal for the appearance of anaerobic oxidation of methane (see section 1.2). Extreme deep-sea environments, such as hydrothermal vents and cold seeps, are characterized by anaerobic oxidation of methane driven by the symbiotic relationship between ANME archaea and SRB (see sections 1.3.2 and 4.1.1). Since sulfate-rich water came to light after the Great Oxygenation Event - although fossils of sulfate-reducers date from 3.4. Ga ago (Duda et al., 2016) - AOM may have been first coupled to oxides of iron and manganese (Beal et al., 2009). These metals are indeed good oxidants due to their potential redox (Beal et al., 2009; Rincón-Tomás et al., 2016). In fact, ANME-1 and ANME-3 archaea have shown in vitro their capability to use metal oxides/hydroxides (i. e. birnessite and ferrihydrite) when cultivated also with sulfate (Beal et al., 2009). Likewise, Scheller et al. 2016 showed that ANME-2 archaea could grow adding soluble ferric iron $\left(\mathrm{Fe}^{3+}\right)$ to the medium. 
Nevertheless, iron and manganese were highly abundant in their reduced form $\left(\mathrm{Fe}^{2+}\right.$, $\mathrm{Mn}^{2+}$ ) in early Archaean (Saito et al., 2003; Zerkle et al., 2005), while their oxidized forms were rare due to lack of strong oxidants. According to Rincón-Tomás et al. 2016, different abiogenically or biogenically mechanisms may have been responsible to oxidize iron and manganese in the early Archaean: (i) the participation of organisms reducing iron and manganese, e. g. Pyrobaculum spp., Shewanella spp., Geobacter spp. (see also Bretschger et al., 2007); (ii) abiogenic chemical (Mn) oxidation due to UV light; and (iii) abiogenic oxidation due to aerobic oases. In the light of the collected findings, it seems the anaerobic oxidation of methane was not sustainable in the early Archaean unless particular conditions (UV light, oxygen oases) or other microorganisms were present. The anaerobic oxidation of methane coupled to metals may have appeared before the increase of sulfate. However, ANME archaea prefer sulfate in the presence of iron and manganese (Beal et al., 2009). This suggests a more suitable settlement of AOM once sulfate compounds increased in the Archaean biosphere. Additionally, the symbiotic interaction between ANME and SRB may be as old as 3.4 Ga (Duda et al., 2016) and its prevalence demonstrates the success of symbiosis as a mechanism of adaption.

\subsection{Reconstructing the tree of life: symbiosis as a successful evolutionary strategy}

The phylogenic tree of life is constantly updated and may never find the perfect representation of the real relationships between organisms. The first phylogenic tree (based on evolution) was illustrated by Charles Darwin in the famous book "On the Origin of Species", according to morphological and physiological observations of certain organisms. Darwin suggested that all living organisms came from a common ancestor and that the variability of environmental conditions influenced the differentiation of organisms belonging to the same clade. In other words, speciation and differentiation between organisms were due to natural selection (Darwin, 1859). Few years after, Mendel's studies demonstrated the inheritance of parental genomic material into their offspring, which have two copies of each gene (one allele from each 
parent). The random acquisition of one of those copies would determine the genotype and phenotype of the offspring (Mendel, 1866). In the early $20^{\text {th }}$ century, the branch of genetics together with mathematicians gave rise to the neo-Darwinism (or the modern synthesis), the theory of evolution which is currently the basis for modern evolutionary biology. Neo-Darwinism introduced the connection between the natural selection of Darwin and the inheritance of genes from parents to descendants of Mendel. This theory claims that evolution is based on random mutations, which are the cause of heritable variability. Natural selection acts directly on the genomic material, by selecting those mutations which are favorable for the organisms and culminates with the speciation of a community (see Fisher, 1930; Huxley, 1942; Gould, 2002 for a review).

\subsubsection{Goodbye neo-Darwinism, welcome horizontal interactions}

Nowadays, neo-Darwinism is accepted and stablished as the basis of evolutionary and phylogenetic biology, although it has suffered improvements since its origin and many of their statements are currently questioned. For instance, epigenetics is a mechanism that introduces variability in the genome due to environmental changes and thus it does not confer randomness (Jaenisch \& Bird, 2003). Furthermore, the punctual equilibrium theory claims that speciation is not a slow process that happens through gradual mutations, rather it occurs rapidly due to a sudden environmental change (i. e. isolation of a group) (Gould, 2002). In any case, current phylogenetic trees generated with new data and technologies, are based in the concept of speciation as a result of divergence, in which new species have separated from their common ancestor due to genomic mutations. However, the formation of new organisms due to symbiosis — defined as symbiogenesis (Mereschkowsky, 1910; Margulis, 2010) — is also widely accepted in the scientific community.

A major step in evolution has been the origin of the eukaryotic cell, leading to an explosion of new organisms and multicellular life (e. g. Roeselers \& Newton, 2012). Although the origin of the nuclear membrane and other organelles remains unknown, it is accepted that the origin of mitochondria and chloroplasts was due to symbiosis 
(Sagan, 1967). Furthermore, terrestrial colonization of photosynthetic organisms also an important step in the history of evolution — was due to symbiosis of alga with fungi, which gave the machinery to alga to survive in dry environments while fungi now could benefit from fixed carbon by means of photosynthesis (De Bary, 1879; Aanen \& Eggleton, 2017). In this case, this symbiosis is considered as permanent and it has created a new clade, the lichens. Likewise, the arrival of multicellular plants on land is also believed that depended on a symbiosis with fungi (Relman, 2008; Aanen \& Eggleton, 2017 and references therein). These remarkable events in evolution due to symbiosis are not represented in the classical phylogenetic trees (see Open Tree of Life, 2018). Similar to lichens and plants, other cases of speciation have occurred due to permanent symbiosis between organisms, but no reflection of this is observed in evolutionary studies. Reports from various fields in biosciences demonstrate the success of symbiosis as a mechanism of adaption in diverse ecosystems, but without considering its role as a main motor of speciation. For instance, marine chemosynthetic invertebrates, which species are only found in reduced environments, are well known to live in symbiosis with prokaryotic organisms, which allow them live in those extreme environments (see Cavanaugh et al. 2006 and Dubilier et al. 2008 for a review). This speciation is the result of symbiosis, since those invertebrates and their symbionts constitute unique species, all as a whole. Although in most of these invertebrates endosymbionts are newly uptake each generation - they have certainly co-evolved with Gammaproteobacteria (see section 4.1.2) - , the appearance of a new species on the phylogenic tree (e. g. Sclerolinum contortum), and therefore the reason why they have separated from their shallow-water relatives (Projecto-Garcia et al., 2010; Zhang et al., 2017), is because they live in symbiosis with chemosynthetic prokaryotes. Additionally, Hug et al. (2016) have constructed a tree of life with a new phylum (Candidate Phyla Radiation), based on genomic and metagenomic databases from uncultured bacteria. Interestingly, the bacteria included in this group are known to have a reduced genome and restricted metabolic capacities, which indicate that they are potential undescribed endosymbionts. 
Consequently, the tree of life is not so divergent, but convergent. Symbiosis and horizontal gene transfer (also an important source of genomic material acquisition and variability, see section 4.2) form the basis for key ecological and evolutionary innovations. Next steps in evolutionary biology should attempt to re-define the adaptative mechanisms that organisms use to ultimately becoming new species. New phylogenic trees need to be done, including horizontal interactions as the motor of speciation (Katz \& Swithers, 2003; Kiers et al., 2015; Nakazawa, 2018).

\subsubsection{Why symbiosis?}

Symbiotic relationships may be facultative or permanent, depending on the evolving time of those interactions and environmental pressure. Natural selection would lead to a permanent symbiosis or symbiogenesis if needed, i. e. the origin of eukaryotic cells, lichens or chemosynthetic mussels. However, if the conditions do not change or changes do not imply the need of a big re-adaptation, facultative symbiosis may be beneficial and stable, i. e. ANME archaea may interact with different partners, not only SRB (Beal et al., 2009; Knittel \& Boetius, 2009). Changes in environment conditions (e. g. due to colonization of new habitats) suppose for organisms the need to adapt to new circumstances to survive. To do so, they must go through genetical mutations and physiological modifications to ultimately have the optimal machinery and features required for the new habitat. These re-adjustments cost energy and time for the organisms, which may not be able to survive if the given conditions are too harsh. Luckily, acquiring an already adapted partner from the harsh environment seems to solve the time problem. Likewise, this partner provides at least one of the physiological modifications required by the environment.

Symbiotic interactions occur only in circumstances where the net costs of adapting to each other (e. g. siboglinid worms creating a special organ for their endosymbionts, the trophosome) are much lower than the net costs of modifying their metabolisms and physical characteristics by themselves. Interestingly, this must be the case. The presence of symbiosis as a mechanism of adaption in the most important events of evolution and the plenty examples given in extreme deep-sea ecosystems and other 
ecosystems denotes its success. Many important events in evolutionary biology and the history of life point out the relevance of symbiosis as an important mechanism of adaption. However, the lack of studies addressing this issue difficults its argumentation. Thus, there is a need to re-evaluate the tree of life and evolution from an ecological perspective, since studies that focus on the different given ecosystems evidence that indeed symbiosis must be the motor of evolution.

\subsection{References}

Aanen, D., and Eggleton, P.: Symbiogenesis: Beyond the endosymbiosis theory?, J. Theor., Biol., 434, 99-103, 2017.

Bartlett, D. H.: Microbial Adaptations to the Psychrosphere/Piezosphere, J. Mol. Microb. Biotech., 1(1), 93-100, 1999.

Battistuzzi, F. U., and Hedges, S. B.: A Major Clade of Prokaryotes with Ancient Adaptations to Life on Land, Mol. Biol. Evol., 26(2), 335-343, 2009.

Beal, E. J., House, C. H., and Orphan, V. J.: Manganese- and Iron-Dependent Marine Methane Oxidation, Science, 325, 184-187, 2009.

Blumenberg, M., Seifert, R., Reitner, J., Pape, T., and Michaelis, W.: Membrane lipid patterns typify distinct anaerobic methanotrophic consortia, PNAS, 101(30), 11111-11116, 2004.

Boetius, A., Ravenschlag, K., Schubert, C. J., Rickert, D., Widdel, F., Gieseke, A., Amann, R., Jørgensen, B. B., Witte, U., and Pfannkuche, O.: A marine microbial consortium apparently mediating anaerobic oxidation of methane, Nature, 407, 623-626, 2000.

Bordenstein, S. R. and Theis, K. R.: Host biology in light of the microbiome: ten principles of holobionts and hologenomes, PLOS Biol., 13(8), e1002226, 2015.

Bretschger, O., Obraztsova, A., Sturm, C. A., Chang, I. S., Gorby, Y. A., Reed, S. B., Culley, D. E., Reardon, C. L., Barua, S., Romine, M. F., Zhou, J., Beliaev, A. S., Bouhenni, R., Saffarini, D., Mansfeld, F., Kim, B.-H., Fredrickson, J. K., and Zhou, J.: Current production and metal oxide reduction by Shewanella 
oneidensis MR-1 wild type and mutants. Appl. Environ. Microb., 73(21), 7003-7012, 2007.

Cavanaugh, C. M., Mickiness, Z. P., Newton, I. L. G., and Stewart, F. J.: Marine Chemosynthetic Symbioses, Prokaryotes, 1, 475-507, 2006.

Cui, M., Ma, A., Qi, H., Zhuang, X., and Zhuang, G.: Anaerobic oxidation of methane: an "active" microbial process, MicrobiologyOpen, 4(1), 1-11, 2015.

Cunha, M. R., Rodrigues, C. F., Génio, L., Hilário, A., Ravara, A., and Pfannkuche, O.: Macrofaunal assemblages from mud volcanoes in the Gulf of Cadiz: abundance, biodiversity and diversity partitioning across spatial scales, Biogeosciences, 10, 2553-2568, 2013.

D’ Amico, S., Collins, T., Marx, J. C., Feller, G., and Gerday, C.: Psychrophilic microorganisms: challenges for life, EMBO Rep., 7(4), 385-389, 2006.

Darwin, C.: On the Origin of Species by Means of Natural Selection, John Murray, London, 1859.

De Bary, A.: Die Erscheinung der Symbiose, Verlag von Karl, J., Trübner, Strassburg, 1879.

De Maayer, P., Anderson, D., Cary, C. and Cowan, D. A.: Some like it cold: understanding the survival strategies of psychrophiles, EMBO Rep., 15(5), 508-517, 2014.

Douglas, A. E., and Werren, J. H.: Holes in the Hologenome: Why Host-Microbe Symbioses Are Not Holobionts, mBio, 7(2), e02099-15, 2016.

Dubilier, N., Bergin, C., and Lott, C.: Symbiotic diversity in marine animals: the art of harnessing chemosynthesis, Nat. Rev. Microbiol., 6(10), 725-740, 2008.

Duda, J.-P., Van Kranendonk, M. J., Thiel, V., Ionescu, D., Strauss, H., Schäfer, N., and Reitner, J.: A Rare Glimpse of Paleoarchean Life: Geobiology of an Exceptionally Preserved Microbial Mat Facies from the 3.4 Ga Strelley Pool Formation, Western Australia, PLOS One, 11(1), e0147629, 2016.

Duperron, S., Gaudron, S. M., Rodrigues, C. F., Cunha, M. R., Decker, C., and Olu, K.: An overview of chemosynthetic symbioses in bivalves from the North Atlantic and Mediterranean Sea, Biogeosciences, 10, 3241-3267, 2013. 
Embley, T. M., and Martin, W.: Eukaryotic evolution, changes and challenges, Nature, 440, 623-630, 2006.

Fisher, R.: The Genetical Theory of Natural Selection, Oxford University Press, Oxford, 308 pp., 1930.

Gould, S. J.: The Structure of Evolutionary Theory, Harvard University Press, Cambridge, 1433 pp., 2002.

Hansson, L., Agis, M., Maier, and C., Weinbauer, M. G.: Community composition of bacteria associated with cold-water coral Madrepora oculata: within and between colony variability, Mar. Ecol. Prog. Ser., 397, 89-102, 2009.

Hay, S., Evans, R. M., Levy, C., Loveridge, E. J., Wang, X., Leys, D., Allemann, R. K., and Scrutton, N. S.: Are the catalytic properties of enzymes from piezophilic organisms pressure adapted?, ChemBioChem, 10(14), 2348-2353, 2009.

Hilário, A., Capa. M., Dahlgren, T. G., Halanych, K. M., Little, C. T. S., Thornhill, D. J., Verna, C., and Glover, A. G.: New Perspectives on the Ecology and Evolution of Siboglinid Tubeworms, PLoS ONE, 6(2), e16309, 2011.

Hinrichs, K.-U.: Microbial fixation of methane carbon at $2.7 \mathrm{Ga}$ : Was an anaerobic mechanism possible?, Geochem. Geophy. Geosy., 3(7), 1-10, 2002.

Holland, H. D: Volcanic gases, black smokers, and the Great Oxidation Event. Geochim. Cosmochim. Ac., 66(21), 3811-3826, 2002.

Hug, L. A., Baker, B. J., Anantharaman, K., Brown, C. T., Probst, A. J., Castelle, C. J., Butterfield, C. N., Hernsdorf, A. W., Amano, Y., Ise, K., Suzuki, Y., Dudek, N., Relman, D. A., Finstad, K. M., Amundson, R., Thomas, B. C., and Banfield, J. F.: A new view of the three of life, Nat. Microbiol., 1, 16048, 2016.

Huxley, J. S.: Evolution: The Modern Synthesis, Allen and Unwin, London, 648 pp., 1942.

Jaenisch, R., and Bird, A.: Epigenetic regulation of gene expression: how the genome integrates intrinsic and environmental signals, Nat. Genet., 33, 245-254, 2003. 
Katz, L., and Swithers, K.: Reconstructing the Tree of Life, Microbe Magazine, 8(6), 249-253, 2013.

Kellogg, C. A., Goldsmith, D. B., and Gray, M. A.: Biogeographic Comparison of Lophelia-Associated Bacterial Communities in the Western Atlantic Reveals Conserved Core Microbiome, Front. Microbiol., 8(796), 1-15, 2017.

Kiers, E., and West, S. A.: Evolving new organisms via symbiosis, Science, 348, 392 394, 2015.

Kleiner, M., Petersen, J. M., and Dubilier, N.: Convergent and divergent evolution of metabolism in sulfur-oxidizing symbionts and the role of horizontal gene transfer, Curr. Opin. Microbiol., 15(5), 621-631, 2012.

Knittel, K., and Boetius, A.: Anaerobic oxidation of methane: progress with an unknown process, Annu. Rev. Microbiol., 63, 311-334, 2009.

Koga, Y.: Thermal Adaptation of the Archaeal and Bacterial Lipid Membranes, Archaea, 2012, 1-6, 2012.

Lau, E., Fisher C., Steudler, P. A., and Cavanaugh, C. M.: The Methanol Dehydrogenase Gene, mxaF,asa Functional and Phylogenetic Marker for Proteobacterial Methanotrophs in Natural Environments, PLoS ONE, 8(2), e56993, 2013.

Lauro, F. M., Roger, A. C., Blankenship, L. E., Yayanos, A. A., and Bartlett, D. H.: The Unique 16S rRNA Genes of Piezophiles Reflect both Phylogeny and Adaptation, Appl. Environ. Microb., 73(3), 838-845, 2007.

León, R., Somoza, L., Medialdea, T., Vázquez, J. T., González, F. J., López-González, N., Casas, D., Mata, M. P., Fernández-Puga, M. C., Giménez-Moreno, C. J., and Díaz-del-Río, V.: New discoveries of mud volcanoes on the Moroccan Atlantic continental margin (Gulf of Cádiz): morpho-structural characterization, Geo-Mar. Lett., 32, 473-488, 2012.

Margulis, L. and Fester, R. (Eds.): Symbiosis as a source of evolutionary innovation, MIT Press, 470, 1991.

Margulis, L., and Sagan, D. (Eds.): Microcosmos: four billion years of microbial evolution, University of California Press, London, 304 pp., 1986. 
Margulis, L.: Symbiogenesis. A new principle of evolution rediscovery of Boris Mikhaylovich Kozo-Polyansky (1890-1957), Paleontol., 44, 1525-1539, 2010. Medialdea, T., Somoza, L., Pinheiro, L. M., Fernández-Puga, M. C., Vázquez, J. T., León, R., Ivanov, M. K., Magalhães, V., Díaz-del-Río, V., and Vegas, R.: Tectonics and mud volcano development in the Gulf of Cádiz, Mar. Geol., 261, 48-63, 2009.

Meier, D. V., Pjevac, P., Bach, W., Hourdez, S., Girguis, P. R., Vidoudez, C., Amann, R., and Meyerdierks, A.: Niche partitioning of diverse sulfur-oxidizing bacteria at hydrothermal vents, ISME J., 11(7), 1545-1558, 2017.

Mendel, G.: Versuche über Pflanzen-Hybriden, in: In: Verhandlungen des Naturforschenden Vereines in Brünn, 3-47, 1866.

Mereschkowsky, C.: Theorie der zwei Plasmaarten als Grundlage der Symbiogenesis, einer neuen Lehre von der Entstehung der Organismen, Biol., Zbl., 30, 278 303, 1910.

Minic, Z.: Organisms of deep sea hydrothermal vents as a source for studying adaptation and evolution, Symbiosis, 47, 121-132, 2009.

Nakazawa, H.: What is the ultimate ancestor? Evidence from fossils and genes analyses, in: Darwinian Evolution of Molecules, Advances in Geological Science, Springer, Singapore, 31-54, 2018.

Nelson, K. E., Clayton, R. A., Gill, S. R., Gwinn, M. L., Dodson, R. J., and Haft, D.H.: Evidence for lateral gene transfer between Archaea and bacteria from genome sequence of Thermotoga maritima, Nature, 399, 323-329, 1999.

Niemann, H., Duarte, J., Hensen, C., Omoregie, E., Magalhães, W. H., Elvert, M., Pinheiro, L. M., Kopf, A., and Boetius, A.: Microbial methane turnover at mud volcanoes of the Gulf of Cadiz, Geochimica, 70, 5336-5355, 2006.

O' Malley, M. A.: From endosymbiosis to holobionts: Evaluating a conceptual legacy, J. Theor. Biol., 434, 34-41, 2017.

Ochman, H., Lawrence, J. G., and Groisman, E. A.: Lateral gene transfer and the nature of bacterial innovation, Nature, 405, 299-304, 2000. 
Odintsova, M. S., and Yurina, N. P.: Plastid genomes of higher plants and algae: structure and functions, Mol. Biol., 37, 649-662, 2003.

Open Tree of Life: https:// tree.opentreeoflife.org, last access: October 112018.

Pagé, A., Tivey, M. K., and Reysenbach, A. L.: Tempora and spatial archaeal colonization of hydrothermal vent deposits, Environ. Microbiol. 10(4), 874884, 2008.

Peckmann, J., Reimer, A., Luth, U., Luth, C., Hansen, B.T., Heinicke, C., Hoefs, J., and Reitner, J.: Methane-derived carbonates and authigenic pyrite from the northwestern Black Sea, Mar. Geol., 177, 129-150, 2001.

Peckmann, J., Thiel, V., Michaelis, W., Clari, P., Gaillard, C., Martire, L., and Reitner, J.: Cold seep deposits of Beauvoisin (Oxfordian; southeastern France) and Marmorito (Miocene; northern Italy): microbially induced authigenic carbonates, Int. J. Earth Sci., 88(1), 60-75, 1999.

Petersen, J. M.: Diversity and Ecology of Chemosynthetic Symbioses in Deep-Sea Invertebrates, Ph.D. thesis, Bremen University, Germany, 230 pp., 2009.

Pinheiro, L. M., Ivanov, M. K., Sautkin, A., Akhmanov, G., Magalhães, V. H., Volkonskaya, A., Monteiro, J. H., Somoza, L., Gardner, J., Hamouni, N., and Cunha, M. R.: Mud volcanism in the Gulf of Cádiz: results from the TTR-10 cruise, Mar. Geol., 195, 131-151, 2003.

Projecto-Garcia, J., Zorn, N., Jollivet, D., Schaeffer, S. W., Lallier, F. H., and Hourdez, S.: Origin and evolution of the unique tetra-domain hemoglobin from the hydrothermal vent scale worm Branchipolynoe. Mol. Biol., 27, 143-152, 2010.

Reed, C. J., Lewis, H., Trejo, E., Winston, W., and Evilia, C.: Protein Adaptations in Archaeal Extremophiles, Archaea, 2013, 1-14, 2013.

Reitner, J., Peckmann, J., Blumenberg, M., Michaelis, W., Reimer, A., and Thiel, V.: Concretionary methane-seep carbonates and associated microbial communities in Black Sea sediments, Palaeogeogr., Palaeoclimatol., Palaeocl., 227, 18-30, $2005 a$. 
Reitner, J., Peckmann, J., Reimer, A., Schumann, G., and Thiel, V.: Methane-derived carbonate build-ups and associated microbial communities at cold seeps on the lower Crimean shelf (Black Sea), Facies, 51, 66-79, 2005 b.

Relman, D.: 'Til death do us part': Coming to terms with symbiotic relationships, Nat. Rev. Microbiol., 6(10), 721-724, 2008.

Rincón-Tomás, B., Khonsari, B., Mühlen, D., Wickbold, C., Schäfer, N., HauseReitner, D., Hoppert, M., and Reitner, J.: Manganese carbonates as possible biogenic relics in Archean settings, Int. J. Astrobiol., 15(3), 219-229, 2016.

Rodrigues, C. F., Cunha, M. R., Génio, L., and Duperron, S.: A complex picture of associations between two host mussels and symbiotic bacteria in the Northeast Atlantic, Naturwissenschaften, 100, 21-31, 2013a.

Rodrigues, C. F., Hilário, A., and Cunha, M. R.: Chemosymbiotic species from the Gulf of Cadiz (NE Atlantic): distribution, life styles and nutritional patterns, Biogeosciences, 10, 2569-2581, 2013b.

Roeselers, G., and Newton, I.: On the evolutionary ecology of symbioses between chemosynthetic bacteria and bivalves, Appl. Microbiol. Biot., 94(1), 1-10, 2012.

Rosenberg, E., Sharon, G., Zilber-Rosenberg, I.: The hologenome theory of evolution contains Lamarckian aspects within a Darwinian framework, Environ. Microbiol., 11, 2959-2962, 2009.

Rotaru, A. E. and Thamdrup, B.: A new diet for methane oxidizers, Science, 351(6274), 658-660, 2016.

Rueda, J. L., González-García, E., Marina, P., Oporto, T., Rittierott, C., LópezGonzález, N., Faria, C., Moreira, J., López, E., Megina, C., López-González, P. J., García Raso, J. E., Gofas, S., Salas, C., Bruque, G., López, F. J., Vázquez, J. T., Fernández-Salas, L. M., and Díaz-del-Río, V.: Biodiversity and geodiversity in the mud volcano field of the Spanish margin (Gulf of Cádiz), MIA Symposium, 2012.

Rueda, J. L., González-García, E., Krutzky, C., López-Rodríguez, F. J., Bruque, G., López-González, N., Palomino, D., Sánchez, R. F., Tomás Vázquez, J. T., 
Fernández-Salas, L. M., and Díaz-del-Río, V.: From chemosynthesis-based communities to cold-water corals: Vulnerable deep-sea habitats of the Gulf of Cádiz, Mar. Biodiv., 46, 473-482, 2016.

Saito, M. A., Sigman, M. and Morel, F. M. M.: The bioinorganic chemistry of the ancient ocean: the co-evolution of cyanobacterial metal requirements and biogeochemical cycles at the Archean/Proterozoic boundary?, Inorg. Chim. Ac., 356, 308-318, 2003.

Sagan (Margulis), L.: On the origin of mitosing cells, J. Theoret. Biol., 14, 225-274, 1967.

Scheller, S., Yu, H., Chadwick, G. L., McGlynn, S. E., and Orphan, V. J.: Artificial electron acceptors decouple archaeal methane oxidation from sulfate reduction, Science, 351(6274), 703-707, 2016.

Sommer, S., Linke, P., Pfannkuche, O., Schleicher, T., Schneider v. Deimling, J., Reitz, A., Haeckel, M., Flögel, S., and Hensen, C.: Seabed methane emissions and the habitat of frenulate tubeworms on the Captain Arutyunov mud volcano (Gulf of Cadiz), Mar. Ecol. Prog. Ser., 382, 69-86, 2009.

Summers, Z. M., Fogarty, H. E., Leang, C., Franks, A. E., Malvankar, N. S., and Lovley, D. R.: Direct exchange of electrons within aggregates of an evolved syntrophic coculture of anaerobic bacteria, Science, 330(6009), 1413-1415, 2010.

Ueno, Y., Yamada, K., Yoshid, N., Maruyama, S., and Isozaki, Y.: Evidence from fluid inclusions for microbial methanogenesis in the early Archaean era Yuichiro, Nature, 440, 516-519, 2006.

Valentine, D. L., and Reeburgh, W. S.: New perspectives on anaerobic methane oxidation, Environ. Microbiol., 2(5), 477-484, 2000.

Van Rooij, D., Depreiter, D., Bouimetarhan, I., De Boever, E., De Rycker, K., Foubert, A., Huvenne, V., Réveillaud, J., Staelens, P., Vercruysse, J., Versteeg, W., and Henriet, J.-P.: First sighting of active fluid venting in the Gulf of Cadiz. Eos, 86(49), 509-511, 2005. 
Wang, Q., Cen, Z., and Zhao, J.: The Survival Mechanisms of Thermophiles at High Temperatures: An Angle of Omics, Physiology, 30, 97-106, 2015.

Wehrmann, L. M., Templer, S. P., Brunner, B., Bernasconi, S. M., Maignien, L., and Ferdelman, T. G.: The imprint of methane seepage on the geochemical record and early diagenetic processes in cold-water coral mounds on Pen Duick Escarpment, Gulf of Cadiz, Mar. Geol., 282, 118-137, 2011.

Wolfe, J. M., and Fournier, G. P.: Horizontal gene transfer constrains the timing of methanogen evolution, Nat. Ecol. Evol., 2(5), 897-903, 2018.

Zerkle, A., House, C. H. and Brantley, S. L.: Biogeochemical signatures trough time as inferred from whole microbial genomes. Am. J. Sci. 305, 567-502, 2005.

Zhang, Y., Sun, J., Chen, C., Watanabe, H. K., Feng, D., Zhang, Y., Chiu, J. M. Y., Qian, P.-Y., and Qiu, J. W.: Adaptation and evolution of deep-sea scale worms (Annelida: Polynoidae): insights from transcriptome comparison with a shallow-water species, Sci. Rep.-UK, 7, 46205, 2017.

Zientz, E., Dandekar, T., and Gross, R.: Metabolic interdependence of obligate intracellular bacteria and their insect hosts, Microbiol. Mol. Biol. R., 68, 745$770,2004$.

\subsection{Supplementary data}

\subsubsection{Environmetal 16S rDNA library of Beggiatoa-like biofilms (Anastasya MV)}

An extended area of Beggiatoa-like biofilms was found in Anastasya MV during the Deep-Links project onboard R/V Celtic Explorer (Fig. 1, E from chapter 3). Five different biofilms (Event_2, Event_4, Event_5, Event_6, and Event_7) were sampled and used for metagenomic analysis using Illumina MiSeq sequencing. Results revealed high abundance of chemosynthetic microorganisms, i. e. methane-oxidizing bacteria, sulfide-oxidizing bacteria, sulfate-reducing bacteria and methane oxidizing archaea. Interestingly, DNA related to the bacteria given the withish-hairy aspect to the biofilms, i. e. Beggiatoa and Candidatus Allobeggiota represented between ca. 5-35\% of the relative abundance in the samples (Fig. S1). The highly presence of other 
chemosynthetic microorganisms reflects the complexicity of these biofilms, as well as the richness in microbial biomass, representing a major sink of hydrocarbon-rich seeping fluids. 

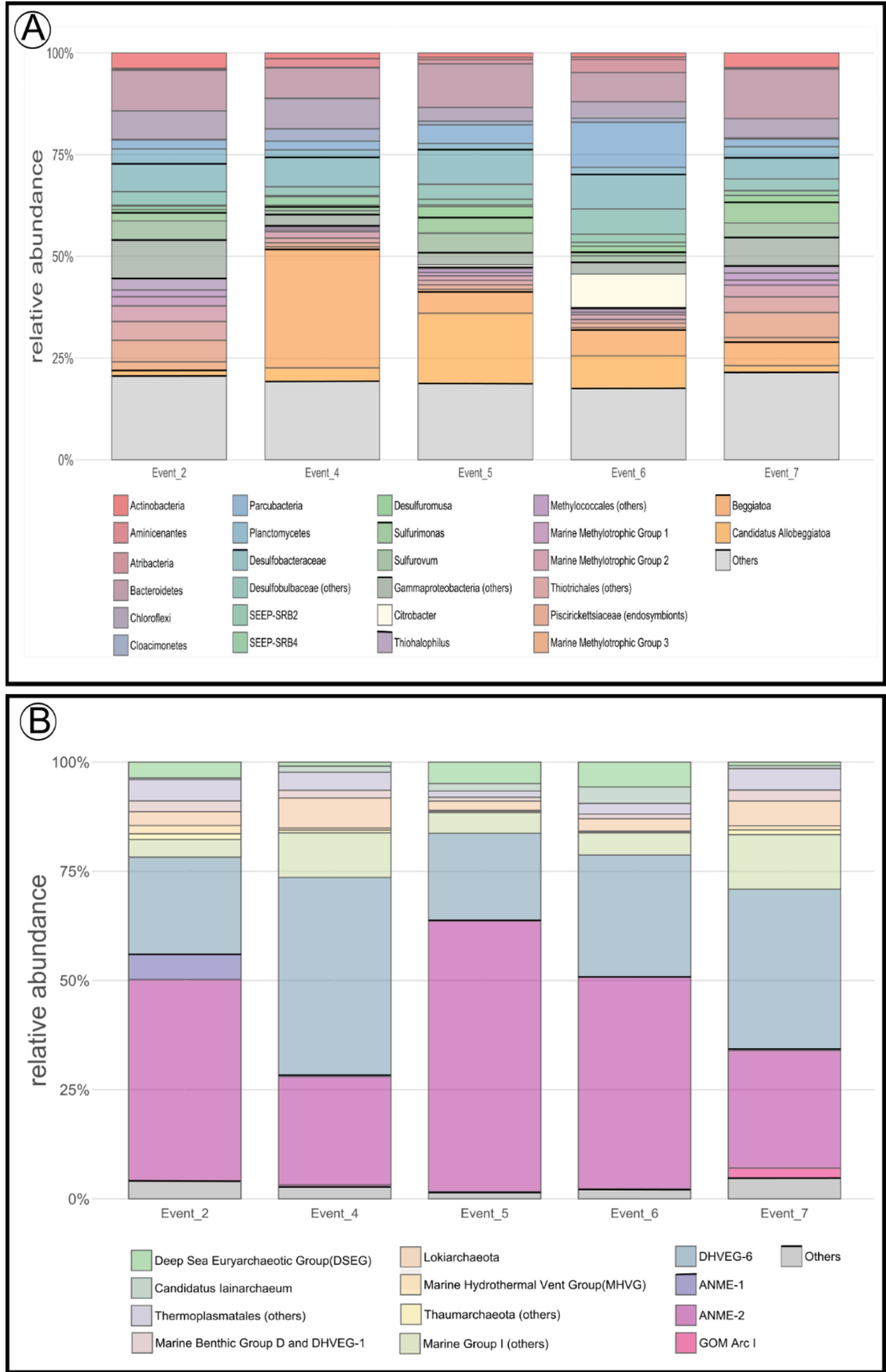

Figure S1: bacterial (A) and archaeal (B) environmental 16S rDNA libraries from different Beggiatoalike biofilms in Anastasya MV. Each column represents one biofilm. Siboglinid worms were found underneath Event_5 biofilm and used for furthers studies in chapter 3. 


\subsubsection{Small AOM-carbonate clasts in El Cid MV}

Push-core sampling was performed in El Cid MV in an area characterized by mounds of bioturbaction and grey mounds, during the Subvent-2 project onboard R/V Sarmiento de Gamboa. Sample D10-C4 was taken from a grey mound and observed under the lupe for preliminary approaches. The sediment revealed siboglinid worms (Fig. 1, B from chapter 3) and small AOM-carbonate clasts (Fig. S2), which increased the porosity of the sediment.

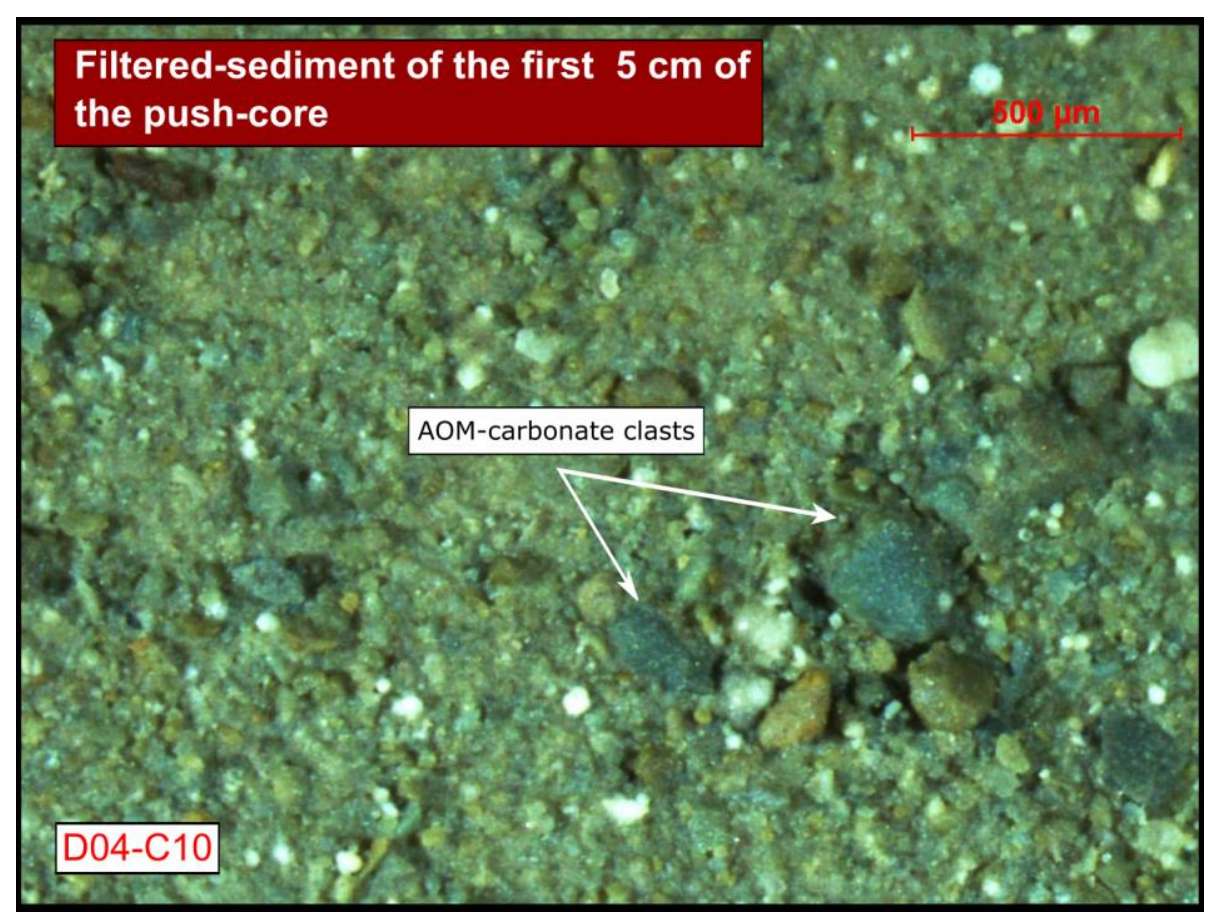

Figure S2: first $5 \mathrm{~cm}$ of sediment from push-core D10-C4, sampled in a field of mounds of bioturbation and grey mounds in El Cid MV. Siboglinid worms and AOM-carbonate clasts were found in the sample. Worms were used for further studies in chapter 3. This image was ceded from Javier González, Geological Survey of Spain IGME. 


\section{Conclusions}

The Gulf of Cádiz is currently affected by active tectonics and nowadays many of the mud volcanoes are displaying dripping-like and difussed seepage. In this study, the Pompeia Province and Anastasya MV happen to be the most active regions, while the Bonjardim and El Cid mud volcanoes seem to have been active in the past and only residual hydrogen sulfide and mud breccia under the first layers of sediment were detected. Furthermore, chemosynthetic and non-chemosynthetic organisms are able to happen coetaneously when fluids are emitted onto the seafloor, as observed in the Al Gacel MV and Nothern Pompeia Coral Ridge. Cold-water corals (non-chemosynthetic) are able to colonize carbonates - coral carbonates and currently forming AOMderived carbonates - by virtue of chemosynthetic AOM-related organisms and sulfide-oxidizers (siboglinid worms, bacterial mats) that consume the emitted fluids. Thus, they prevent dissolution of the corals due to environmental acidification and their intoxication. Additionally, small chemosynthetic siboglinid worms happen generally in the mud volcanoes of the Gulf of Cádiz. They harbor methanotrophic or thiotrophic bacteria depending on the environmental conditions, although most of the clades seem to have a preference for thiotrophs. Interestingly, their tubes harbor a high diversity of microbial organisms that vary due to seepage activity. This extended microbiota of the siboglinids appears to interact in a way with the worm, including symbiotic and commensalistic relationships. Consequently, the worms' holobiont is more extended as previously thought and it brings up the need for further studies to understand better the functioning of the interactions given in a holobiont, i. e. siboglinids, corals and organisms in general.

In light of our findings and consulted studies, symbiosis is a successful mechanism of adaption in extreme deep-sea environments, being the most abundant form of chemosynthesis. The anaerobic oxidation of methane is a major reaction in these habitats and is driven by the symbiosis between anaerobic methane-oxidizing archaea (ANME) and sulfate-reducing bacteria (SRB). Likewise, invertebrate animals normally found in these environments, i. e. tubeworms and bivalves, have adapted to 
the extreme conditions by modifying their physiology but, most importantly, by living in symbiosis with chemosynthetic microorganisms. They have found a way to take advantages of the abundance of compounds like sulfide and methane, by using them as a source of carbon and energy. Additionally, these animals have become primary producers, reducing the loss of energy from a trophic perspective. Furthermore, observing symbiosis widely distributed in extreme deep-sea environments denotes its importance in evolution. On the one hand, animals living in these habitats come from shallower waters and they have been able to colonize new extreme habitats via symbiosis. On the other hand, the anaerobic oxidation of methane is at least $2.7 \mathrm{Ga}$ years old and the preference of ANME archaea to oxidize methane coupled to sulfate reducers indicates their co-evolution must suppose great benefits for both.

Other successful arrivals of organisms to harsh environments through the history of evolution - the adquisition of mitochondria, the origin of lichens or the terrestrial colonization of multicellular plants - have been also due to symbiosis, pointing to its relevance not only in reduced ecosystems, but in nature. Therefore, we point to the need of incorporating changes into the phylogenetic tree of life, as well as into the basis of the theory of evolution. These changes must include symbiosis and horizontal gene transfer as motors of evolution, and undermain relevance to random genome mutations or epigenetics, which play an important role in gradual microevolution, but not in the important evolutionary steps of life. 


\section{Acknowlegdements}

First of all, I would like to thank Dr. Michael Hoppert and Prof. Joachim Reitner for the great opportunity they have given me with this project. I always liked microbiology, but I never knew I could be so passionate about the microbial world. Besides, I became a huge fan of geology and I cannot wait to keep learning about rocks, biomineralization and Earth's history. They have inspired me to want to become a super scientist.

I also would like to thank the Spanish geologists from the Geological Survey of Spain (IGME), Prof. Luis Somoza, Dr. Teresa Medialdea, Dr. Esther Santofimia, Dr. Enrique López Pamo and Egidio Marino. I could not have asked for a better team to work with. Scientific cruises can be hard sometimes, but they have always been there to teach me in a nice working environment. Luis has been always kind and has provide me the best experiences collaborating with them. They receive me everytime I go to their institute with affection and friendliness, and it makes me think about how lucky I am having such good colleagues. Furthermore, I want to thank Dr. Javier González for his constant support and patience. He has been available and supportive everytime I needed, and I feel I would have not gotten this far without his help.

I could not be more grateful to Cynthia Chibani and Ignacio Rodríguez Polo (Nacho), who have been supporting me everyday through my Ph.D. The cool side mensa team is always there. We have laughed together, cried together and they have even fed me when hard times were coming. I will never forget our coffees outside, no matter if it rained or snowed. I further would like to thank David López and Elina Galani, who have always look after me like if they were my parents, and I have always run to them when I needed their wisdom. I look up to them and I cannot be luckier having them as my models. Leticia Domínguez-Parrilla has always given me love and laughs and I miss her ever since she left Göttingen. They all (including Lydia Domínguez-Parrilla, Iliana Gialama, and Carlos Lamda) had played an important role during my Ph.D., helping me and caring for me, being my home during these last years.

Last but not least, I want to dedicate this thesis to my family. Annabel and Lola have been the most supportive living beings I could even have. Lola has always forgiven 
me my long days of work. Everytime I see her moving her tail happily, I know she loves me and cares for me. Annabel has played the major role these last years, loving me unconditionally and doing everything she could to help me and support me. I know for her this thesis is part of her life too, and that is why I want her to know how grateful I am. THANK YOU!

Gracias a Silvia, Ingrid y Nora por los buenos momentos en el departamento. Me habéis alegrado cada día con vuestra compañía. Gracias a mi madre y a mi padre, que me han criado y han hecho siempre lo posible porque llegue a ser la persona que soy hoy en día. Gracias a mi hermano y al resto de mi familia, que su amor y constante compañía me dan fuerzas para seguir adelante con mi carrera.

Metralleta de besitos 